UNIVERSIDADE DE BRASÍLIA

PROGRAMA DE PÓS-GRADUAÇÃO EM AGRONOMIA

FACULDADE DE AGRONOMIA E MEDICINA VETERINÁRIA

CARACTERÍSTICAS AGRONÔMICAS E QUALIDADE DA ALFACE (Lactuca sativa L.) SOB FERTILIZAÇÃO ORGÂNICA E MINERAL

ANNA PAULA RODRIGUES DOS SANTOS

TESE DE DOUTORADO EM AGRONOMIA

BRASÍLIA/DF

FEVEREIRO/2016 


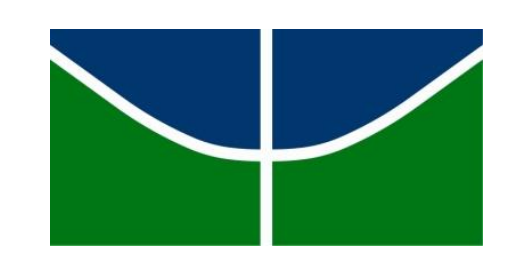

\author{
UNIVERSIDADE DE BRASÍLIA \\ FACULDADE DE AGRONOMIA E MEDICINA VETERINÁRIA \\ PROGRAMA DE PÓS-GRADUAÇÃO EM AGRONOMIA
}

CARACTERÍSTICAS AGRONÔMICAS E QUALIDADE DA ALFACE (Lactuca sativa L.) SOB FERTILIZAÇÃO ORGÂNICA E MINERAL

ANNA PAULA RODRIGUES DOS SANTOS

ORIENTADORA: ANA MARIA RESENDE JUNQUEIRA, PhD.

TESE DE DOUTORADO EM AGRONOMIA

040D/2016 


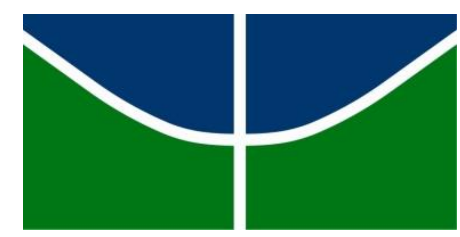

UNIVERSIDADE DE BRASÍLIA

FACULDADE DE AGRONOMIA E MEDICINA VETERINÁRIA PROGRAMA DE PÓS-GRADUAÇÃO EM AGRONOMIA

\section{CARACTERÍSTICAS AGRONÔMICAS E QUALIDADE DA ALFACE (Lactuca sativa L.) SOB FERTILIZAÇÃO ORGÂNICA E MINERAL}

ANNA PAULA RODRIGUES DOS SANTOS

TESE SUBMETIDA AO PROGRAMA DE PÓSGRADUAÇÃO EM AGRONOMIA, COMO PARTE DOS REQUISITOS NECESSÁRIOS À OBTENÇÃO DO GRAU DE DOUTOR EM AGRONOMIA.

APROVADA POR:

Ana Maria Resende Junqueira, Ph.D. Universidade de Brasília (UnB) CPF- 340.665.511-49. E-mail: anamaria@unb.br (Orientadora)

Ernandes Rodrigues de Alencar, Dr. Universidade de Brasília (UnB) CPF- 900.558.021-68. E-mail: ernandesalencar@unb.br (Examinador Interno)

Jean Kleber de Abreu Mattos, Dr. Universidade de Brasília (UnB) CPF- 002.288.181-68. E-mail: jkamattos@gmail.com (Examinador Interno)

Márcio de Carvalho Pires, Dr. Universidade de Brasília (UnB) CPF- 844.256.601-53. E-mail: mcpires@ unb.br (Examinador Externo)

Michelle Souza Vilela, $\mathrm{Dr}^{\mathrm{a}}$. (UnB)

CPF- 919.623.401-63. E-mail: michellevilelaunb@gmail.com (Examinadora Externa)

BRASÍLIA/DF, 29 DE FEVEREIRO DE 2016. 


\section{FICHA CATALOGRÁFICA}

Santos, Anna Paula Rodrigues dos.

Características agronômicas e qualidade da alface (Lactuca sativa L.) sob fertilização orgânica e mineral./Anna Paula Rodrigues dos Santos; orientação de Ana Maria Resende Junqueira. - Brasília, 2016.

114 p.; il

Tese de Doutorado (D) - Universidade de Brasília/Faculdade de Agronomia e Medicina Veterinária, 2016.

1. Lactuca sativa L. 2. Contaminação 3. Pigmentos fotossintéticos 4. Perfil metabólico. I. Junqueira, A.M.R. II. Título. Ph.D.

\section{REFERÊNCIA BIBLIOGRÁFICA}

SANTOS, A.P.R dos. Características agronômicas e qualidade da alface (Lactuca sativa L.) sob fertilização orgânica e mineral. Brasília: Faculdade de Agronomia e Medicina Veterinária, Universidade de Brasília, 2016, 114 p. Tese de Doutorado.

\section{CESSÃO DE DIREITOS}

NOME DO AUTOR: Anna Paula Rodrigues dos Santos

TÍTULO DA TESE: Características agronômicas e qualidade da alface (Lactuca sativa L.) sob fertilização orgânica e mineral

GRAU: Doutor ANO: 2016

É concedida à Universidade de Brasília de Brasília permissão para reproduzir cópias desta tese de doutorado para única e exclusivamente propósitos acadêmicos e científicos. $\mathrm{O}$ autor reserva para si os outros direitos autorais, de publicação. Nenhuma parte desta tese de doutorado pode ser reproduzida sem a autorização por escrito do autor. Citações são estimuladas, desde que citada à fonte.

Nome: Anna Paula Rodrigues dos Santos

CPF: 717.320.471-20

Tel. (61) 9556-1345 Email: anna.rods@gmail.com 
A minha querida vovó Jesuína Gomes Rodrigues (in memoriam), com todo amor e gratidão.

DEDICO 


\section{AGRADECIMENTOS}

A Deus, porque Dele e por Ele, e para Ele, são todas as coisas.

À minha mãe Eliete e minha doce avó Jesuína (in memoriam), que sempre me apoiaram e mostraram que com perseverança e fé podemos alcançar nossos objetivos e sonhos. Sem seu amor, compreensão e ajuda financeira, este objetivo não seria alcançado.

Meu pai Paulo Roberto dos Santos (in memoriam) e meu avô Oto Rodrigues (in memoriam), por todo ensinamento e amor.

À minha irmã Anna Flávia e meus sobrinhos Júlia e Samuel, por todo amor, incentivo e muito companheirismo que muito me motiva na busca de meus objetivos.

À professora Ana Maria Resende Junqueira, meu profundo agradecimento pela orientação, preocupação, apoio e carinho. Sou grata pelos ensinamentos, pela confiança depositada em minha pessoa, pelo suporte e pela presença constante em todas as etapas dos trabalhos e por participar de várias fases de minha vida acadêmica, da graduação ao doutoramento.

Aos professores, servidores e alunos do Programa de Pós-Graduação em Agronomia da Universidade de Brasília, que contribuíram para a concretização do curso.

Ao Israel e toda equipe da horta da Fazenda Água Limpa (FAL-UnB), pelo auxílio fundamental no experimento de campo.

Aos alunos do PET Agronomia UnB e do CVT - UnB pelo apoio no trabalho pesado e risadas garantidas.

Aos professores Thomas Williams, Michelle de Souza Fayad André e mestrando Tiago Batista Moreira do Instituto de Biologia (IC-UnB), agradeço pelos ensinamentos e pelo espaço cedido para a realização da análise do perfil metabólico.

À professora Michelle de Sousa Vilela pelo auxílio estatístico com o programa SPSS.

À professora Ângela Patrícia, Viviane, Flávia e Nara por ceder o Laboratório de Análise Microbiológica de Alimentos (LAMAL- FAV- UnB), para realização das análises microbiológicas.

Aos amigos e irmãos da Igreja Evangélica da Comunhão de Brasília, por seus preciosos conselhos e orações.

Ao CNPq, pela bolsa concedida e apoio financeiro oferecido durante anos.

A todos que de alguma forma me ajudaram a chegar até aqui. 
"Não fui eu que lhe ordenei? Seja forte e corajoso! Não se apavore, nem desanime, pois o Senhor, o seu Deus, estará com você por onde você andar" 


\section{RESUMO}

O presente trabalho teve como objetivo avaliar a performance da cultura de alface, $\mathrm{cv}$. Vanda sob fertilização orgânica e mineral com o enfoque para características agronômicas e de qualidade do produto. Foram realizados três experimentos na Fazenda Água Limpa FAL-UnB, Brasília-DF, em um período compreendido entre agosto de 2012 a julho de 2015, com delineamento com blocos ao acaso, 10 tratamentos em quatro repetições. Em 2012 e 2013 os tratamentos foram: 1. adubação química (controle); 2. composto orgânico; 3. esterco bovino; 4. esterco ovino; 5. esterco de aves; 6. cama de frango; 7. adubação química + esterco bovino; 8. adubação química + esterco ovino; 9. adubação química + esterco de aves; 10. adubação química + cama de frango. No ano de 2015, os tratamentos foram: 1. Sem adubação (controle); 2. adubação química; 3. composto orgânico; 4. esterco bovino; 5. esterco ovino; 6. esterco de aves; 7. adubação química + esterco bovino; 8. adubação química + esterco ovino; 9. adubação química + esterco de aves; 10. adubação química + composto. As variáveis avaliadas foram: produção de massa fresca e seca, presença de microrganismos (Samonella spp. e Coliformes termotolerantes) e metais pesados (chumbo e cádmio), concentração de pigmentos fotossintéticos (clorofila $a$, clorofila $b$, clorofila total e carotenóides) e perfil metabólico. Verificou-se que a produção de massa fresca e seca foi similar em todos os tratamentos nos anos de 2012 e 2013. No ano de 2015, a produção foi significativamente superior nas plantas fertilizadas com esterco de aves que diferiu do tratamento controle e do tratamento com plantas sob fertilização química. Porém, não diferiu do observado nos demais tratamentos. Não foi observada contaminação das plantas de alface por metais pesados e microrganismos independente da fonte de fertilização. Não foi observada diferença entre os tratamentos para a concentração de pigmentos fotossintéticos. Foi observada diferença estatística entre tratamentos para nove metabólitos. Destaque para o acúmulo de piroglutamato que apresentou-se mais elevado em plantas sob fertilização orgânica e em plantas sob fertilização orgânica e mineral comparados ao observado em plantas sob fertilização mineral apenas.

PALAVRAS-CHAVE: Lactuca sativa L., contaminação, pigmentos fotossintéticos, perfil metabólico. 


\begin{abstract}
This research aimed to evaluate the performance of lettuce, cv. Vanda, grown under organic and mineral fertilization with emphasis to agronomical and quality characteristics. Three experiments were carried out at Fazenda Agua Limpa, Brasilia-DF, from August 2012 to July 2015, with ramdomized block design, 10 treatments and four replicates. On 2012 and 2013, treatments were: 1. chemical fertilization (control); 2. organic compost; 3. cattle manure; 4. sheep manure; 5. chicken manure; 6. chicken bedding material; 7. chemical fertilization + cattle manure; 8. chemical fertilization + sheep manure; 9. chemical fertilization + chicken manure; 10 . chemical fertilization + chicken bedding material. On 2015 treatments were: 1. no fertilization (control); 2. chemical fertilizaton; 3. organic compost; 4. cattle manure; 5 . sheep manure; 6. chicken manure; 7. chemical fertilization + cattle manure; 8. chemical fertilization + sheep manure; 9. chemical fertilization + chicken manure; 10. chemical fertilization + organic compost. Variables evaluated were: fresh and dry matter production, microorganisms' contamination (Samonella spp. and fecal coliformes), heavy metals (cadmium and lead), photossyntetic pigments (clorophile $a$, clorophile $b$, total clorophile and carotenoids) and metabolic profile. It was observed that lettuce fresh and dry matter production were similar for all treatments on 2012 and 2013. On 2015, fresh matter production was significantly superior under chicken manure compared to control and chemical fertilization treatment. But it did not differ between chicken manure and all the others treatments. There were no differences between treatments for photossyntetic pigments' concentration. There were differences among treatments for nine metabolites. Piroglutamate was significantly higher on lettuce plants from organic fertilization, on general, and on plants from mixed fertilization, containing animal manure, compared to plants from chemical fertilization only.
\end{abstract}

KEYWORDS: Lactuca sativa L, contamination, photossyntetic pigments, metabolic profile. 


\section{SUMÁRIO}

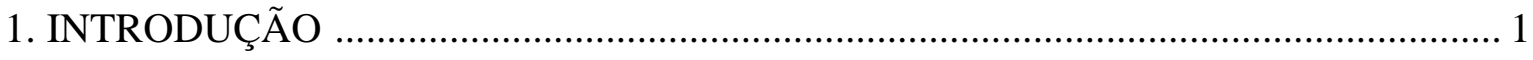

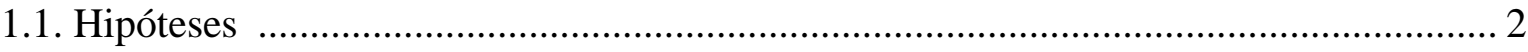

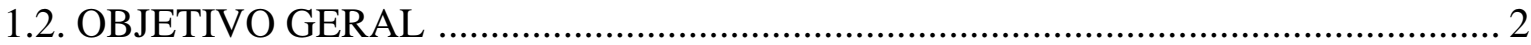

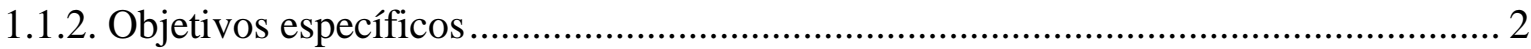

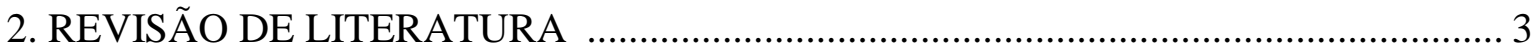

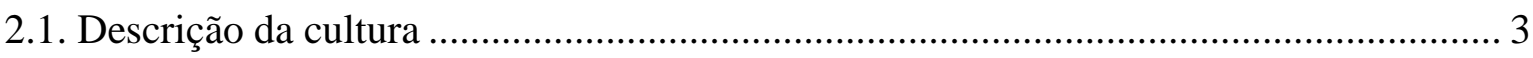

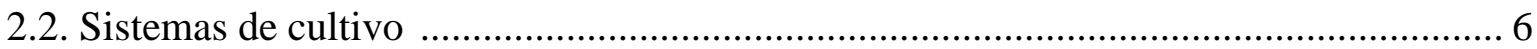

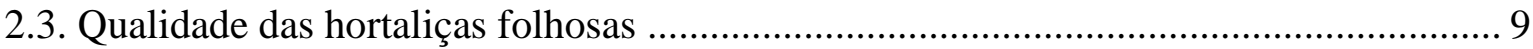

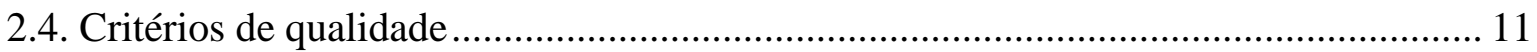

2.4.1. Desempenho agronômico de culturas ........................................................................... 11

2.4.2. Segurança do alimento e a qualidade microbiológica ........................................... 12

2.4.3. Teor de clorofilas $a$ e $b$, clorofila total $(a+b)$ e carotenóides totais........................... 14

2.4.4. Valor nutritivo de alimentos orgânicos e convencionais ........................................... 16

2.4.5. Perfil metabólico pelo método da cromatografia gasosa e espectros de massas (GC-

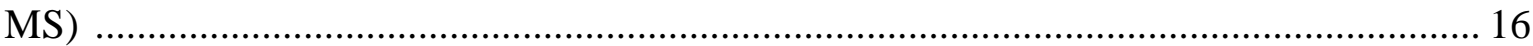

2.4.5.1. Importância de alguns metabólitos no desenvolvimento vegetal .......................... 17

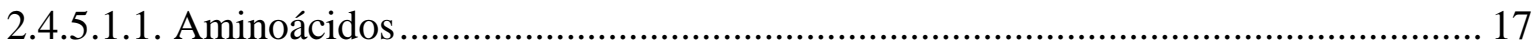

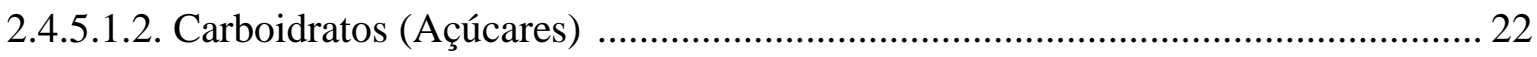

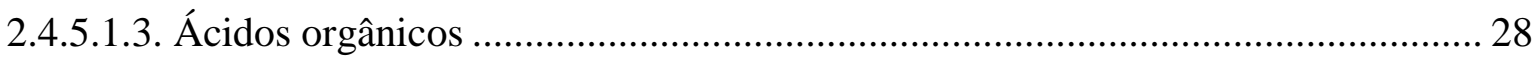

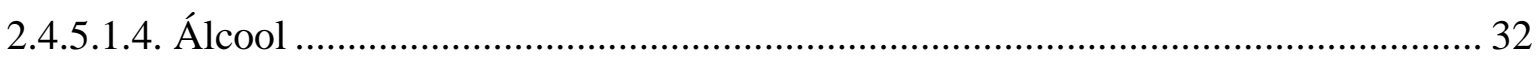

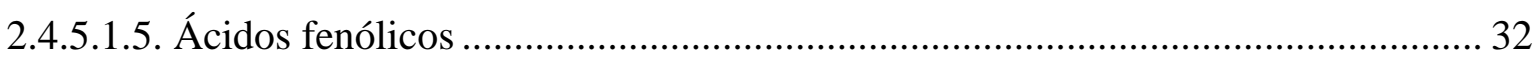

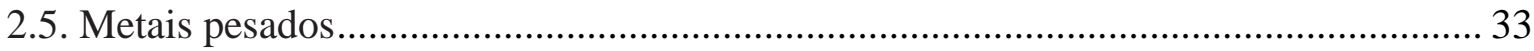

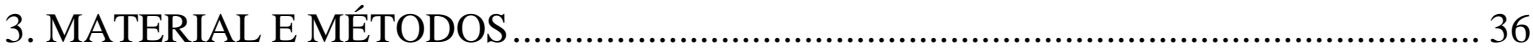

3.1. Avaliação de características agronômicas das plantas de alface ................................. 41

3.2. Avaliação da presença de metais pesados e microrganismos ...................................... 42

3.3. Quantificação do teor de clorofilas $a$ e $b$, clorofila total $(a+b)$ e carotenóides totais... 44

3.4. Perfil metabólico de plantas de alface 45 
4.1. Desempenho agronômico das plantas de alface ....................................................... 47

4.2. Contaminação de alface por cádmio, chumbo e microrganismos .............................. 53

4.3. Teor de clorofilas $a$ e $b$, clorofila total $(a+b)$ e carotenóides totais em plantas de alface

4.5. Descrição do perfil metabólico e substâncias identificadas em folhas de alface 67

5. CONCLUSÕES .78

6. CONSIDERAÇÕES FINAIS .79

6. REFERÊNCIA 80

ANEXO 1. Tabela Número Mais provável (NMP) 100

ANEXO 2. Padrões Microbiológicos Sanitários para Alimentos 101

ANEXO 3. Compostos não significativos, em unidades arbitrárias por mg, em folhas de alface provenientes de plantas cultivadas no período de agosto a outubro de 2012 sob diferentes tipos de fertilização. 102

ANEXO 4. Compostos não significativos, em unidades arbitrárias por mg,em folhas de alface provenientes de plantas cultivadas no período de fevereiro a abril de 2013 sob diferentes tipos de fertilização. 103 


\section{INTRODUÇÃO}

A preservação do meio ambiente e a melhoria da qualidade de vida constituem uma preocupação cada dia mais evidente da sociedade. Por isso o consumo de alimentos deixou de ser uma parte da vida cotidiana antes aceita de forma inconsciente, para tornar-se alvo de maior atenção, principalmente no que diz respeito à saúde.

Atualmente, o papel da nutrição vai além da ênfase sobre a importância de uma dieta balanceada. Além da nutrição adequada, busca-se maximizar as funções fisiológicas, incrementar a saúde e bem-estar e reduzir riscos de doenças. Com isso, a demanda por alimentos mais saudáveis e produzidos por meio de sistemas de cultivo sustentáveis incrementou o consumo de produtos provenientes da agricultura orgânica ou similares.

Neste contexto, a discussão acerca da acumulação de metais pesados, contaminação microbiológica e qualidade nutricional em alimentos merece destaque.

Para um alimento efetivamente seguro, todos os agentes envolvidos na cadeia produtiva devem estar conscientes da necessidade de adoção de práticas amparadas em programas, normas e padrões que visem garantir as condições adequadas do produto.

É necessário trabalhar para a produção de alimentos seguros à saúde e que atendam às demandas dos consumidores, como um dos suportes para o desenvolvimento da agricultura e pecuária. Com isso, será possível garantir a segurança e qualidade dos produtos, aumentar a produção, produtividade e competitividade, além de atender às exigências dos mercados internacionais e à legislação brasileira.

Pesquisas de metaboloma, ou seja, a análise dos metabólitos, que é um dos mais promissores segmentos da biotecnologia, estudos envolvendo presença de microrganismos, metais pesados, quantificação de pigmentos fotossintéticos foram utilizados para gerar informações que possam desmistificar crenças de que o sistema orgânico de cultivo é arcaico e atrasado devendo ser foco de trabalhos científicos como forma de alavancar sistemas agrícolas de base agroecológica em seus diversos aspectos.

Neste caso, em particular, buscou-se avaliar aspectos quantitativos e qualitativos da planta de alface sob fertilização orgânica e mineral, com o intuito de contribuir para o incremento do conhecimento acerca da produção orgânica vegetal e de auxiliar no esclarecimento sobre mitos e crenças que muitas vezes permeiam o debate sobre a performance de culturas sob sistemas de cultivo ditos alternativos. 


\subsection{Hipóteses}

- A utilização de fertilização química aumenta a produtividade das culturas em detrimento dos resultados observados sob fertilização orgânica.

- O uso de estercos animais e compostos orgânicos aumentam os riscos de contaminação do produto agrícola por microrganismos patogênicos e metais pesados.

- Vegetais produzidos com estercos animais e compostos orgânicos apresentam incremento na qualidade nutricional e funcional em detrimento dos resultados observados sob fertilização química.

\subsection{OBJETIVO GERAL}

Avaliar a performance da cultura de alface (Lactuca sativa L.) cv. Vanda sob fertilização orgânica e mineral com o enfoque para características agronômicas e de qualidade do produto.

\subsubsection{Objetivos específicos}

- Avaliar o efeito da fertilização orgânica e mineral sobre características agronômicas observadas em plantas de alface;

- Avaliar o efeito da fertilização orgânica e mineral sobre a presença de Salmonella spp., coliformes fecais (coliformes termotolerantes) e de metais pesados, chumbo e cádmio, em plantas de alface;

- Avaliar o efeito da fertilização orgânica e mineral sobre a concentração de pigmentos fotossintéticos em plantas de alface;

- Identificar os metabólitos presentes em plantas de alface sob fertilização orgânica e mineral, com destaque para aqueles de maior expressividade. 


\section{REVISÃO DE LITERATURA}

\subsection{Descrição da cultura}

A alface (Lactuca sativa L.) pertence à família Asteraceae, gênero Lactuca, no qual estão identificadas mais de 100 espécies. Originou-se de espécies silvestres, ainda encontradas em regiões de clima temperado, no sul da Europa e na Ásia Ocidental (FILGUEIRA, 2003). É a hortaliça folhosa mais consumida no Brasil e apresenta em sua constituição nutricional, cálcio e vitaminas A e C e vitaminas B1 e B2. Possui propriedades tranquilizantes, alto teor de vitaminas A, B e C, além de cálcio, fósforo, potássio e outros minerais. Apresenta baixo teor calórico (FERNANDES et al., 2002; VIGGIANO, 1990).

É uma planta anual, herbácea, muito delicada, folhas grandes e de consistência variada em função de variedades. A planta é herbácea, com caule diminuto ao qual se prendem as folhas, as quais são amplas e crescem em roseta, em volta do caule. O sistema radicular é muito ramificado e superficial, explorando apenas os primeiros $25 \mathrm{~cm}$ de solo, quando a cultura é transplantada. Em semeadura direta, a raiz pivotante pode atingir até $60 \mathrm{~cm}$ de profundidade. Condições ambientais de temperaturas amenas e dias curtos favorecem a etapa vegetativa do ciclo (FILGUEIRA, 2003). A temperatura ideal para o desenvolvimento está na faixa de $15,5^{\circ} \mathrm{C}$ e $18,3{ }^{\circ} \mathrm{C}$, apesar de tolerar faixas entre $26,6^{\circ} \mathrm{C}$ a $29,4{ }^{\circ} \mathrm{C}$, por alguns dias, desde que as temperaturas noturnas sejam baixas (SANDERS, 2013).

As folhas podem ser lisas ou crespas e a coloração verde-clara, verde-escura ou roxa. Podem ser repolhuda com formação de cabeça ou solta, sem formação de cabeça. Em função dessas características, as variedades podem ser separadas em 6 grupos: 1) Tipo repolhuda-manteiga, folhas lisas, verde-amareladas, forma cabeça compacta. Variedades: Brasil 303, Carolina; 2) Tipo repolhuda-crespa (Americana), folhas crespas, bem consistentes, forma cabeça compacta. Variedades: Great Lakes, Tainá, Madona, Lucy Brown; 3) Tipo solta-lisa, folhas lisas, soltas, não forma cabeça. Variedades: Monalisa, Luisa, Regina, Babá-de-verão; 4) Tipo solta-crespa, folhas crespas, soltas, consistentes, não forma cabeça. Variedades: Grand Rapids, Marianne, Verônica, Vanessa e Marisa; 5) Tipo Mimosa, folhas delicadas, aspecto arrepiado, não forma cabeça. Variedades: Salad Bowl, Greenbowl; 6) Tipo Romana, folhas alongadas, consistentes, forma cabeça fofa (FILGUEIRA, 2003). 
Os primeiros relatos da cultura da alface ocorreram no Egito onde se supõe que a utilizavam como forrageira e para extração de óleo das sementes. Em pinturas encontradas nas tumbas dos túmulos egípcios em 4.500 a.C., a alface assemelhava-se ao tipo romana, que eram plantas de folhas lanceoladas e pontudas (FERAKOVA, citado por RYDER, 1986). Do Egito, o cultivo difundiu-se para Grécia e Roma. Com a descoberta do Novo Mundo, a alface espalhou-se rapidamente neste Continente e em 1647 já era cultivada no Brasil. A forma ancestral da alface, L. serriola, é encontrada do Mediterrâneo e Ásia central até o Norte da China e Nepal (LINDQUIST, 1960). Na mitologia Grega, a história de amor entre a deusa Afrodite e o jovem Adonis teve um fim dramático quando esse último foi morto por um porco selvagem na horta das alfaces no qual ele estava escondido. Nessa mitologia, a alface foi assim simbolicamente relacionada a um aspecto de morte e ainda por cima, a um aspecto de impotência masculina (no coração da história de Adonis). Entretanto, essas diversas conotações mitológicas não parecem ter tido muita influência sobre o povo Romano, pois desde a época do Imperador Domitien, do ano 81 ao ano 96, era costume das elites servir alface como entrada, antes do prato principal, com rabanetes e outros legumes crus (HACQUARD, 1996).

$\mathrm{O}$ cultivo apresenta limitações, principalmente devido sensibilidade às condições adversas de temperatura, umidade e chuva (GOMES et al., 2005; KATAYAMA, 1993). Por apresentar vida pós-colheita curta, as zonas produtoras geralmente concentram-se perto das áreas metropolitanas, conhecidas como "cinturões-verdes" (HENZ e SUINAGA, 2009). É uma planta exigente nutricionalmente e, em sistema convencional, a maioria dos produtores utiliza elevadas doses de adubos solúveis. As altas produtividades alcançadas por uso de adubos químicos e agrotóxicos têm sido questionadas, principalmente, por omitir aspectos qualitativos importantes da produção vegetal (SANTOS et al., 1994). Segundo Porto et al. (1999), o plantio da alface se restringe as pequenas áreas, onde o seu cultivo intensivo, frequentemente, propicia desequilíbrio na fertilidade do solo, causando deficiências minerais e, consequentemente, baixas produtividades.

No Brasil são cultivadas cerca de 200 hortaliças folhosas, como acelga agrião, aipo, almeirão, cebolinha, chicória, coentro, couves, espinafre, mostarda, rúcula, salsa, entre outras. Dentre elas, as de maior importância, considerando-se os volumes produzidos e comercializados, são a alface e o repolho (CASTELLANE, 1994). A alface atualmente é a terceira hortaliça em volume de produção, atrás apenas da melancia e do tomate, e a folhosa mais consumida no Brasil de acordo com a Associação Brasileira do Comércio de 
Sementes e Mudas (ABCSEM). Ainda de acordo com a entidade, a cultura da alface movimenta todos os anos $\mathrm{R} \$ 8$ bilhões no varejo e com uma produção de aproximadamente 1,5 milhões de toneladas ao ano (CULTIVAR, 2015). Em termos de consumo, a principal cultivar é o da alface crespa, com participação no mercado de mais de $50 \%$. A tendência do mercado é a diferenciação da cultivar através da oferta de produtos que atendam as diferentes demandas, se destacando a cultivar Americana, Mimosa e a Mini (CULTIVAR, 2015).

De acordo com dados do Anuário da Agricultura Brasileira, no ano de 2012 no Brasil, foram comercializadas 41.925 toneladas de alface no CEAGESP (CEPEA, 2015), e a área de produção total foi estimada em 39.000 ha (IEA, 2014), sendo os maiores produtores os estados de São Paulo, Minas Gerais e Rio de Janeiro, com 31\%, 27\% e 7\% da produção nacional, respectivamente. A área da safra de verão 2013/14 em Mogi das Cruzes e em Ibiúna, por exemplo, foi de 3.900 e de 5.090 mil hectares, respectivamente de acordo com o Cepea. Em março de 2014, a alface crespa foi comercializada na CEAGESP a R\$ 35,29/cx com 24 unidades, valor 70\% menor que março de 2013. Na safra de dezembro de 2013 a maio de 2014, a alface americana foi comercializada em Mogi das Cruzes em média por $\mathrm{R} \$ 15,37 / \mathrm{cx}$ com 12 unidades, 30\% maior que o mínimo estimado pelos produtores para serem cobertos os gastos com a cultura. A alface crespa foi comercializada na mesma região à média de $\mathrm{R} \$ 13,15 / \mathrm{cx}$ com 20 unidades, valor 39,2\% acima do custo de produção no período, valor estimado pelos produtores (CEPEA, 2015).

No Distrito Federal, apenas no mês de junho de 2007 foram comercializados 163.065 $\mathrm{kg}$ de alface (CEASA-DF, 2007). Em 2013, a área de produção de alface foi de 1.261,05 ha, ocupando $14,83 \%$ da área total de produção do DF. A produção, no mesmo ano foi de 26.238,58 t, responsável por 10,5\% do mercado (EMATER, 2013).

A produção mundial, em 2011, foi da ordem de 23,2 milhões de toneladas anuais, liderando, no ranking mundial, a China, com 13,4 milhões de toneladas, seguida pelos Estados Unidos, com 4,07 milhões de toneladas e Índia, com 1,06 milhões de toneladas (FAO, 2013). O consumo per capita catarinense de alface é de 1,5kg/ano, superior ao consumo médio per capita brasileiro (1,2kg/ano), considerado baixo pela Organização Mundial da Saúde (IBGE, 1989). 


\subsection{Sistemas de cultivo}

Filgueira (2003) e Resende et al. (2007) relatam que no Brasil existem pelo menos quatro sistemas produtivos de alface que são o cultivo convencional e o sistema orgânico em campo aberto, o cultivo protegido no sistema hidropônico e no solo.

De acordo com Hirakuri et al. (2012), sistema de cultivo relaciona-se às práticas comuns de manejo aplicadas a uma determinada espécie vegetal, objetivando-se produzir a partir de "uma combinação lógica e ordenada de um conjunto de atividades e operações".

O sistema de cultivo convencional utiliza técnicas tradicionais de preparo de solo e controle fitossanitário, seguido, em geral os passos: remoção da vegetação; aração; calagem; gradagem; semeadura; adubação mineral, que é aquela realizada com adubos extraídos de rochas, que são recursos naturais não renováveis, ou produzidos em indústrias químicas; controle fitossanitário com agroquímicos; capinas e, colheita. Fundamenta-se no revolvimento de camadas superficiais para reduzir a compactação, incorporação de corretivos e fertilizantes, aumento dos espaços porosos e, com isso, eleva a permeabilidade e o armazenamento de ar e água, facilitando o crescimento das raízes das plantas. Além disso, o revolvimento do solo promove o corte e o enterrio das plantas daninhas e auxilia no controle de pragas e patógenos do solo (DE FREITAS et al., 2010).

O preparo convencional é realizado em duas etapas, que são o preparo primário e o secundário. O objetivo do preparo primário é fornecer condições ideais para a germinação, a emergência e o estabelecimento das plântulas, além de reduzir a população inicial de plantas invasoras, permitir o aumento da infiltração de água, diminuindo as perdas de água e sedimentos por erosão a um mínimo tolerável. Consiste na operação mais grosseira, realizada com arados ou grades pesadas. O preparo secundário consiste na operação de destorroamento e de nivelamento da camada arada de solo por meio de gradagens do terreno (DE FREITAS et al., 2010).

De acordo com Altierie e Nicholls (2005), o sistema convencional de produção está em crise, pois ignorou princípios ecológicos causando graves impactos ambientais. Um crescente número de pessoas tornou-se preocupada com a sustentabilidade dos sistemas de produção de alimentos existentes. Evidências mostram que, enquanto sistemas agrícolas intensivos em tecnologia têm sido extremamente produtivos e competitivos, eles também trazem uma variedade de problemas econômicos, ambientais e sociais. Além disso, a própria natureza da estrutura agrícola e das políticas vigentes, conduziram a esta crise ambiental, favorecendo a monocultura e a mecanização. Por sua vez, a falta de rotação e 
diversificação transforma as monoculturas em agroecossistemas altamente vulneráveis dependentes de elevadas doses de insumos químicos, redução das oportunidades ambientes da manutenção de inimigos naturais, tornando as culturas mais suscetíveis a pragas e doenças, que incluem perda de colheita, perda de recursos genéticos, eliminação de inimigos naturais, ressurgimento de pragas e resistência genética a pesticidas, contaminação química e destruição dos mecanismos de controle naturais.

O sistema de cultivo orgânico visa à produção de alimentos em um contexto capaz de integrar o homem ao meio ambiente (SANTOS e MONTEIRO, 2004). A agricultura orgânica tem como princípios e práticas encorajar e realçar ciclos biológicos dentro do sistema de agricultura para manter e aumentar a fertilidade do solo, minimizar todas as formas de poluição, evitar o uso de fertilizantes sintéticos e agrotóxicos, manter a diversidade genética do sistema de produção, considerar o amplo impacto social e ecológico do sistema de produção de alimentos e produzir alimentos de qualidade em quantidade suficiente (IFOAM, 1998). É a união de processos de produção que tem como pressuposto básico a ideia de que fertilidade é obtida diretamente da matéria orgânica contida no solo.

No cultivo agroecológico, o suprimento de elementos minerais e químicos necessários para o desenvolvimento das culturas é resultado da ação de microrganismos presentes nos compostos biodegradáveis existentes ou colocados no solo. Além disso, a existência de uma abundante fauna microbiana diminui os desequilíbrios ocasionados pela intervenção humana na natureza. Nutrição adequada e ambiente equilibrado proporcionam plantas mais vigorosas e mais resistentes a doenças e pragas (ORMOND et al., 2002). Os adubos orgânicos são obtidos a partir da decomposição de restos de plantas ou de fezes de animais (estercos) pela ação dos microrganismos e de minhocas. Possuem vários nutrientes minerais, especialmente nitrogênio, fósforo e potássio e, embora sua concentração seja considerada baixa, deve-se levar em conta, também, o efeito condicionador que exercem sobre o solo (FORNASIERI FILHO, 1992). A alface produzida em sistema orgânico, além de apresentar ótimos resultados de ordem produtiva e nutricional pode apresentar reduzidos teores de nitrato (COMETTI et al., 2004; YURI et al., 2004; SANTOS et al., 2001).

De acordo com Vilela et al. (2006), as principais vantagens do consumo de orgânicos frente aos convencionais estão relacionadas ao menor índice de toxicidade e à manutenção do equilíbrio ambiental e, para o produtor, as vantagens do sistema estão relacionadas à 
não utilização dos produtos químicos, visto que um grande número de agricultores não utiliza equipamentos de proteção. A oferta de produtos de melhor qualidade aos consumidores e a promoção da melhoria da qualidade de vida para produtores e comunidades próximas aos locais de produção, diminuição considerável da contaminação ambiental são destacadas por Panzenhagen et al. (2008). O não uso de defensivos agrícolas ajudaria a evitar uma série de doenças, entre elas, dermatoses, cânceres e sequelas neurológicas, segundo Azevedo (2006), citado por Badue (2007).

Outra vantagem em relação ao sistema convencional está relacionada às pragas que deveriam ser controladas pelos produtos químicos, mas acabam tornando-se resistentes a eles (BARBIERI, 2006; BADUE, 2007). A produção orgânica possui um custo alto de implantação, porém os custos de manutenção são inferiores aos da produção tradicional, pois existe a possibilidade de utilizar insumos existentes na propriedade. Além disso, os produtos químicos utilizados na agricultura convencional são em bom número importados, sujeitos às variações de preço do câmbio. $\mathrm{O}$ fato de o cultivo orgânico exigir mais mão-deobra, gerando empregos ou o aproveitamento da própria mão-de-obra familiar, pode ser considerado uma vantagem (BRITO e CARVALHO, 2004).

As principais dificuldades do sistema orgânico estão relacionadas principalmente a uma mudança nos padrões de produção e consumo e a falta de ações públicas efetivas principalmente na liberação de crédito para os produtores fazerem a transição para o sistema orgânico (BADUE, 2007). Os custos iniciais são elevados devido a necessidade de adaptações em relação aos métodos convencionais como mudança da infraestrutura produtiva, aquisição de implementos e materiais adequados, sementes, introdução de práticas de preparo e conservação do solo, assistência técnica, entre outros (CAMPANHOLA et al., 2001).

O alto custo para o consumidor se deve à escala de produção reduzida devido ainda ao baixo número de agricultores adeptos ao método orgânico (OLIVEIRA e ALMEIDA JÚNIOR, 2008). A certificação que representa uma garantia de que o produto, processo ou serviço é diferenciado dos demais assegurando ao produtor um diferencial de mercado para os seus produtos, é um processo que tem custos (BRASIL, 2009). Darolt (2000) afirma que os preços cobrados ao consumidor, pelos produtos orgânicos são, em média, 30\% a 100\% maiores do que aqueles cobrados pelos convencionais.

Figueiredo e Tanamati (2010) referem-se ao sistema orgânico, que se vale de métodos alternativos de enriquecimento do solo, como o uso de estercos animais, como um sistema 
que pode resultar em contaminação do solo, da planta e do homem por microrganismos patogênicos e excesso de nitrogênio. Outro risco de contaminação está associado ao consumo de alimentos crus, pois no imaginário popular orgânicos não apresentariam qualquer risco à saúde. Porém Abreu et al. (2010) relatam processos que facilitariam a contaminação de vegetais por Salmonella sp. e coliformes termotolerantes. Além disso, materiais oriundos de resíduos industriais podem acumular materiais pesados também nocivos à saúde humana (FIGUEIREDO e TANAMATI, 2010).

\subsection{Qualidade das hortaliças folhosas}

Qualidade é um conceito subjetivo que está relacionado diretamente às percepções de cada pessoa. Muitos fatores como cultura, mecanismo do pensamento, tipo de produto ou serviço prestado, necessidades e expectativas influenciam diretamente nesta definição. Existem várias definições para qualidade, do ponto de vista de diferentes indivíduos. O termo qualidade vem do latim Qualitas e refere-se à essência das coisas, é utilizado em variadas situações, mas o seu significado nem sempre é de definição clara e objetiva. Em geral, o termo qualidade é empregado para significar excelência de um serviço ou produto (NBR ISO 8402). A qualidade de um produto pode ser observada por duas óticas: do ponto de vista do produtor, a qualidade associa-se à concepção e produção de um produto que vá ao encontro das necessidades do cliente e, do ponto de vista do cliente, a qualidade está associada ao valor e à utilidade reconhecidos no produto (BONILLA, 2003).

A norma ISO 8402 define qualidade como a totalidade de características de uma atividade, processo, produto ou organização que lhe confere a capacidade de satisfazer as necessidades explícitas e implícitas. Necessidades explícitas são aquelas especificadas em contrato. São requisitos que definem as condições em que o produto deve ser utilizado, seus objetivos, funções e o desempenho esperado. Necessidades explícitas são aquelas especificadas em contrato. São requisitos que definem as condições em que o produto deve ser utilizado, seus objetivos, funções e o desempenho esperado. As necessidades implícitas são as que a empresa tem que satisfazer, embora não especificadas em contrato, para obter um diferencial competitivo, pois são necessárias para o usuário. Engloba tanto os requisitos óbvios, como aqueles que não são percebidos como necessários no momento em que o produto foi desenvolvido, mas que pela gravidade de suas consequências devem ser atendidas (NBR ISO 8402). 
Peri (2005) define qualidade do alimento como aptidão para o consumo, aquilo que satisfaz o consumidor. Assim, qualidade do alimento descreve os requerimentos necessários para a satisfação das necessidades e expectativas do consumidor. A preocupação com a qualidade teve seu ápice a partir da $2^{\mathrm{a}}$ Guerra Mundial. Antes disso, a preocupação com a qualidade tinha apenas a finalidade de impedir que produtos com defeito chegassem até o consumidor final, evoluindo para o que hoje é conhecido como Garantia da Qualidade (SILVA, 2005). Os motivos que acarretaram tais alterações foram: a intensa competição entre as organizações, dentro de seus países e fora deles; a diminuição das barreiras comerciais com a criação de grandes blocos econômicos; e, a diminuição do crescimento econômico mundial, em face da consolidação da qualidade de produtos e serviços como sendo fundamental para a sobrevivência das empresas. Os consumidores passaram a exigir maior qualidade nos produtos e serviços a um preço menor. As estratégias de qualidade passam a ser primordiais (PINTO et al., 2006).

Para atingirem o máximo de qualidade na produção de alimentos, as companhias mudaram o foco de atenção, antes baseada na qualidade apenas do produto final, para uma preocupação voltada para a qualidade de todo o processo, enfatizando o controle em cada ponto crítico da produção. A preocupação estende-se para a esfera sistêmica, que necessita da cooperação de todos os envolvidos no sistema agroindustrial (SPERS, 2003; GIANDON, 1994).

Pretty (1982) afirma que determinar a qualidade de uma cultura pode ser ao mesmo tempo algo objetivo e subjetivo, havendo critérios que devem ser considerados para os produtos agrícolas, como por exemplo: substâncias nutricionais básicas: proteínas, carboidratos e minerais, forma física (tamanho, peso, formato) e cor. Qualidade é um atributo de um produto agrícola que aumenta seu valor para o consumidor.

Assim, considerando uma espécie de hortaliça folhosa e nesta apenas uma cultivar, provavelmente o consumidor fará sua escolha considerando as melhores formas físicas e cor, uma vez que ele não dispõe de recursos para avaliar possíveis alterações nas substâncias nutricionais básicas, que podem ocorrer devido um determinado tipo de adubação utilizada, por exemplo.

Deve-se considerar ainda que os padrões de qualidade das folhosas se alteram muito em função da época de cultivo. Durante o verão, o excesso de chuva favorece as doenças e as temperaturas elevadas prejudicam o desenvolvimento vegetativo destas espécies (CASTELLANE, 1994). Assim, pode-se inferir que o produto é de qualidade inferior 
àquele produzido sob condições de inverno. Porém, devido a menor oferta nessa época do ano, seu valor econômico é maior. De acordo com NEPA- UNICAMP (2011), uma porção de $100 \mathrm{~g}$ de alface crespa crua é constituída por (Tabela 1):

Tabela 1- Composição nutricional da alface.

\begin{tabular}{|c|c|c|c|c|c|c|c|c|c|c|c|}
\hline $\begin{array}{c}\text { Umidade } \\
\%\end{array}$ & $\begin{array}{l}\text { Energia } \\
\text { kcal kj }\end{array}$ & & $\begin{array}{c}\text { Proteína } \\
\text { G }\end{array}$ & $\begin{array}{c}\text { Lipídeos } \\
\text { g }\end{array}$ & $\begin{array}{c}\text { Colesterol } \\
\text { mg }\end{array}$ & $\begin{array}{c}\text { Carboidrato } \\
\text { G }\end{array}$ & $\begin{array}{c}\text { Fibra alimentar } \\
\text { g }\end{array}$ & $\begin{array}{c}\text { Cinzas } \\
\mathrm{g}\end{array}$ & $\begin{array}{c}\text { Cálcio } \\
\text { mg }\end{array}$ & \multicolumn{2}{|c|}{$\begin{array}{c}\text { Magnésio } \\
\text { mg }\end{array}$} \\
\hline 96,1 & 1145 & & 1,3 & 0,2 & NA & 1,7 & 1,8 & 0,7 & 38 & 1 & \\
\hline $\begin{array}{c}\mathbf{P} \\
\mathbf{m g}\end{array}$ & $\begin{array}{l}\mathrm{Fe} \\
\mathrm{mg}\end{array}$ & $\begin{array}{l}\mathrm{Na} \\
\mathrm{mg}\end{array}$ & $\begin{array}{c}\mathrm{K} \\
\mathrm{mg}\end{array}$ & $\begin{array}{l}\mathrm{Cu} \\
\mathrm{mg}\end{array}$ & $\begin{array}{c}\text { Retinol } \\
\mu \mathrm{g}\end{array}$ & $\begin{array}{c}\text { REA } \\
\mu \mathrm{g}\end{array}$ & $\begin{array}{cr}\text { Tiamina } & \text { Riboflav } \\
\text { mg } & \text { mg }\end{array}$ & Pir & $\begin{array}{l}\text { doxina } \\
\text { Mg }\end{array}$ & $\begin{array}{c}\text { Niacina } \\
\text { mg }\end{array}$ & $\begin{array}{c}\text { Vit C } \\
\text { mg }\end{array}$ \\
\hline 0,20 & 0,4 & 3 & 267 & 0,03 & NA & 234 & 0,11 & & $\mathrm{Tr}$ & 1,09 & 15,6 \\
\hline
\end{tabular}

Adaptado de NEPA- UNICAMP (2011).

Em estudo realizado por Muller e Hippe (1987), verificou-se que as alterações nos teores de vitaminas, causadas por um determinado nutriente, podem apresentar intensidades bem distintas. $\mathrm{Na}$ alface, por exemplo, ao se alterar o fornecimento de nitrogênio de 0,75 para $1,5 \mathrm{~g}$ por planta houve um incremento de $62 \%$ no teor de vitamina C.

\subsection{Critérios de Qualidade}

\subsubsection{Desempenho agronômico de culturas}

A preocupação com o ambiente e a qualidade de vida é cada vez maior e por isso tem aumentado a demanda por produtos saudáveis e consequentemente a necessidade de se desenvolver sistemas de produção agrícola, baseados na conservação do solo, aporte de nutrientes de fontes renováveis, com base em resíduos orgânicos localmente disponíveis (LINHARES et al., 2009).

Além de ser afetada pelos danos causados pela precipitação, a produtividade da alface também é reduzida por foto inibição, causada por luminosidade elevada (FU et al., 2012).

Fontanétti et al. (2006) afirmam que devido os elevados custos dos fertilizantes químicos e o aumento da salinidade do solo ocasionada por eles, alternativas tem sido usadas para a produção de alface e outras hortaliças. Uma delas é a adubação orgânica de 
várias origens que visa não só melhor as propriedades físicas e químicas do solo, mas também redução das quantidades de adubos químicos que são aplicados. A alface, em geral, apresenta boa resposta à adubação orgânica, mas a resposta varia de acordo com a cultivar e a fonte de adubo utilizada.

De acordo com Pimentel et al. (2009), o padrão comercial de alfaces sofre influência positiva da adubação, uma vez que a parte aérea da planta é maior e mais pesada quando há maior nível de composto orgânico incorporado.

Segundo Turazi et al (2004), os efeitos benéficos do material orgânico sobre as características físicas e químicas do solo, o custo elevado dos adubos minerais solúveis e o marketing realizado em torno da produção orgânica de alimentos têm influenciado no aumento da adoção da adubação orgânica no cultivo de hortaliças nos últimos anos além do incremento na produtividade com o uso do composto orgânico.

\subsubsection{Segurança do alimento e a qualidade microbiológica}

Segurança do alimento ou alimento seguro está relacionada ao termo inglês food safety, que é a garantia do consumidor adquirir um alimento com atributos de qualidade que sejam de seu interesse, entre os quais se destacam os atributos ligados à saúde e segurança. Está ligada ao fornecimento do alimento em quantidade suficiente, seguro e nutritivo e que vai ao encontro às suas necessidades e preferências, necessárias para uma vida ativa e saudável (FAO, 2013; SPERS, 2003).

Substâncias que podem causar perigo para a saúde humana geralmente não podem ser visualizadas externamente em um alimento. Assim, nem todos os atributos podem ser avaliados pelos consumidores no momento da compra. Por isso, o processo produtivo, desde as matérias-primas até a entrega do alimento ao consumidor, deve ser realizado sob padrões específicos de higiene, limpeza e segurança, e estar em constante avaliação para que possa sinalizar ao consumidor que o alimento é seguro (TALAMINI et al., 2005). A segurança do alimento, sob a ótica da qualidade, pode ser alcançada por meio da implementação de um conjunto de práticas interligadas e comuns a todos os agentes da cadeia.

Benevides et al. (2007) afirmam que hoje os consumidores não se contentam em apenas selecionar um produto pelos seus aspectos de sabor, preço e aparência e sim buscam cada vez mais informações sobre a segurança, tais como a procedência dos alimentos, aspectos relacionados ao sistema de produção e cuidados com o ambiente. 
O consumo de hortaliças cruas constitui um importante veículo de transmissão de doenças de origem alimentar. Essa contaminação pode ocorrer antes e após a colheita, por meio do solo, irrigação com água contaminada, transporte e pelas mãos dos manipuladores (MOREIRA et al., 2013; BARROS et al.,2013).

De acordo com Silva (2005), a qualidade microbiológica dos alimentos está diretamente relacionada com a presença tanto de microrganismos deteriorantes, que irão contribuir com as alterações indesejáveis das características sensoriais dos produtos, como cor, odor, textura e aparência, como também de microrganismos patogênicos em concentrações prejudiciais à saúde. Assim, a segurança microbiológica diz respeito à ausência de toxinas microbianas e de microrganismos patogênicos causadores de infecção alimentar.

Os microrganismos patogênicos podem chegar ao alimento por inúmeras vias, sempre refletindo condições precárias de higiene durante a produção e manipulação (FRANCO e LANDGRAF, 2002; SILVA JUNIOR, 2001).

O gênero Salmonella está inserido na família Enterobacteriaceae. Seu habitat natural é o trato intestinal do homem, outros mamíferos e animais que contaminam a água e os alimentos a partir deste reservatório natural. Pode-se disseminar no ambiente principalmente pelo manuseio e outras práticas agrícolas em condições de higiene não satisfatórias e por processos de contaminação cruzada (LEITÃO, 2004).

O índice de coliformes termotolerantes é empregado como indicador de contaminação fecal, ou seja, de condições higiênico-sanitárias deficientes levando-se em conta que a população deste grupo pode indicar outros patógenos internos. Em geral as bactérias do grupo coliformes são prejudiciais aos alimentos (CARDOSO et al., 2008).

As bactérias aeróbias mesófilas são constituídas por espécies de Enterobacteriaceae, Bacillus, Clostridium, Corynebacterium e Streptococcus. A contagem padrão em placa tem sido usada como indicador da qualidade higiênica dos alimentos, indicativo sobre seu tempo útil de conservação (SILVA et al., 1997). Sua presença em grande número indica matéria prima excessivamente contaminada, limpeza e desinfecção de superfícies inadequadas, higiene insuficiente na produção e condições inapropriadas de tempo e temperatura durante a produção ou conservação dos alimentos (SIQUEIRA, 1995). 


\subsubsection{Teor de clorofilas $a$ e $b$, clorofila total $(a+b)$ e carotenóides totais}

As clorofilas e os carotenóides são pigmentos presentes nos vegetais, capazes de absorver a radiação visível, desencadeando as reações fotoquímicas da fotossíntese, processo essencial para a sobrevivência vegetal e por isso denominado metabolismo primário. São os pigmentos naturais mais abundantes presentes nas plantas e ocorrem nos cloroblastos das folhas e em outros tecidos vegetais. Estudos em uma grande variedade de plantas relatam que os pigmentos clorofilianos são os mesmos. As diferenças aparentes na cor do vegetal são devido à presença e à distribuição variável de outros pigmentos associados, como carotenóides, os quais sempre acompanham as clorofilas. A coloração das folhas de alface varia de verde-amarela até verde-escura, e ainda existem algumas cultivares que têm coloração arroxeada devido à presença do pigmento antocianina (ELBE, 2000; REGHIN, 2002).

As clorofilas não são moléculas isoladas, compreendem uma família de substâncias semelhantes, chamadas clorofilas $a, b, c$ e $d$. A clorofila está diretamente relacionada com a atividade fotossintética nas plantas. Assim, o estado nutricional das plantas está relacionado com a qualidade e a quantidade de clorofila (CASSETARI, 2012).

A influência de diferentes faixas do espectro luminoso pode ser avaliada em relação à de pigmentos fotossintéticos. Conforme o pigmento, diferente é a faixa espectral absorvida para desencadear o processo fotossintético. A clorofila $a$ tem absorção máxima na faixa do azul e vermelho, onde está o espectro de ação para a fotossíntese (HALL e RAO, 1980). Após absorção da luz pelos pigmentos, ocorre transferência de energia luminosa que desencadeia os eventos químicos da fotossíntese, como fixação do $\mathrm{CO}_{2}$ e produção de carboidratos (HALL e RAO, 1980; SUN e VOGELMANN, 1998).

A clorofila $a$ é a mais abundante e mais importante dessa família e corresponde a, aproximadamente, $75 \%$ dos pigmentos verdes encontrados nos vegetais (GROSS, 1991). A clorofila $a$ está presente em todos os organismos que realizam fotossíntese oxigênica. As bactérias fotossintetizantes são desprovidas de clorofila $a$ e em seu lugar tem a bacterioclorofila como pigmento fotossintético. A clorofila $a$ é o pigmento utilizado para realizar a fotoquímica (o primeiro estágio do processo fotossintético), enquanto os demais pigmentos auxiliam na absorção de luz e na transferência da energia radiante para os centros de reação, sendo assim chamados de pigmentos acessórios. Os principais pigmentos acessórios também incluem outros tipos de clorofilas, como clorofila $b$, presente em vegetais superiores, algas verdes e algumas bactérias; clorofila c, em feófitas e 
diatomáceas e clorofila $d$, em algas vermelhas (TAIZ e ZIEGER, 2004). Os pigmentos acessórios, como os carotenos, absorvem na faixa do azul e ultravioleta. A influência de diferentes faixas do espectro luminoso pode ser avaliada em relação à de pigmentos fotossintéticos (WELBURN, 1994).

Os pigmentos envolvidos na fotossíntese são as clorofilas $a$ e $b$, os carotenóides e as ficobilinas. A clorofila $b$, os carotenóides e as ficobilinas constituem os chamados pigmentos acessórios. A energia absorvida pelos pigmentos é transferida para sítios bem definidos, localizados sobre as membranas tilacoides, os chamados centros de reação. Há dois centros de reação, um deles absorvendo luz em $680 \mathrm{~nm}$ e outro em $700 \mathrm{~nm}$, os quais interagem entre si por meio de transportadores de elétrons. É a partir da molécula de clorofila, a qual absorve em $680 \mathrm{~nm}$ no espectro visível, que os elétrons oriundos da água são transferidos para a cadeia transportadora de elétrons da fotossíntese (KLUGE, 2005). O teor de clorofilas nas folhas é influenciado por diversos fatores bióticos e abióticos, estando diretamente relacionado com o potencial de atividade fotossintética das plantas (TAIZ e ZEIGER, 2004).

Os pigmentos fotossintéticos são responsáveis pela captação da energia luminosa para funcionamento dos fotossistemas II e I, para a produção de NADH e ATP na fase fotoquímica da fotossíntese (FAYAD-ANDRÉ, 2010). Esses produtos finais serão utilizados na fase de carboxilação para a produção de carboidratos (TAIZ e ZEIGER, 2009). Os carotenóides têm como função primordial, proteger o aparato fotossintético do excesso de energia luminosa por dissipação térmica, porém eles também participam como pigmentos acessórios, na captação de energia luminosa nas membranas fotossintéticas (SIEFERMAN-HARMS, 1987).

Ainda segundo Taiz e Zaiger (2009), os processos fisiológicos são resumidos em acúmulo de nutrientes, desenvolvimento de tecidos jovens dependentes dos nutrientes armazenados, absorção de água e elementos minerais a partir de um substrato, transporte de água e elementos minerais pelo sistema vascular, fotossíntese e utilização, pela planta, das substâncias elaboradas pela fotossíntese.

Existem fatores que influenciam o desempenho da planta e entre eles está a adição de fertilizantes ao solo, que poderá favorecer ou não os processos metabólicos e o desenvolvimento da planta. As alterações metabólicas podem refletir diretamente no crescimento da planta afetando a produtividade e qualidade dos produtos. 


\subsubsection{Valor nutritivo de alimentos orgânicos e convencionais}

Diversos estudos têm sido realizados com o objetivo de comparar a qualidade nutricional de produtos hortícolas provenientes de diferentes sistemas de produção. Alguns indicam um melhor desempenho nutricional aos produtos cultivados no sistema orgânico de produção, outros mostram que não existe diferença significativa entre este e aqueles cultivados em sistemas convencionais (DAROLT, 2005; ROSSETO et al., 2009; MITCHELL et al., 2007; KELLY, 2010).

Segundo Souza e Resende (2003), os alimentos orgânicos apresentam uma composição muito mais diversificada e rica em minerais, aminoácidos, proteínas e fito hormônio, o que proporciona uma nutrição mais adequada para o corpo humano. Todavia, para Darolt et al. (2003) não é tão simples fazer esta afirmativa, pois a qualidade de um alimento precisa ser analisada sob diferentes dimensões, como teores de vitaminas, açúcares e outros elementos que possam dar indicativos da melhor escolha para os consumidores.

De acordo com Bourn e Prescott (2002) e Ren et al.(2001), as considerações sobre o impacto do sistema orgânico de produção na biodisponibilidade de nutrientes e o teor de compostos antioxidantes têm recebido pouca atenção, mas são importantes diretrizes para futuras pesquisas. Estudos com foco no efeito do tipo de fertilizante sobre o valor nutricional do alimento e aqueles que envolvem análises de alimentos comprados no comércio não permitem conclusões claras sobre os impactos do sistema de produção orgânico e convencional sobre a qualidade das hortaliças.

Analisar alimentos provenientes de produções orgânicas e convencionais permite verificar o efeito da fertilização sobre o valor nutricional do material em estudo, possibilitando comparações (BOURN e PRESCOTT, 2002).

\subsubsection{Perfil metabólico pelo método da cromatografia gasosa e espectros de massas (GC-MS)}

O método Cromatografia Gasosa - Espectrometria de Massa (CG-EM) combina as características da cromatografia gasosa e da espectrometria de massa para identificar diferentes substâncias em uma amostra. É amplamente aceito como padrão-ouro na identificação química de compostos orgânicos voláteis e semi-voláteis em misturas, detecção de drogas, análise ambiental, investigação de explosivos e identificação de 
amostras desconhecidas. Além disso, é possível identificar oligoelementos em materiais que passariam despercebidos por outras tecnologias (SMITHS DETECTION, 2013).

O CG-EM é composto de duas partes principais: o cromatógrafo a gás e o espectrômetro de massa. O cromatógrafo a gás utiliza uma coluna capilar que depende das dimensões da coluna (comprimento, diâmetro e espessura de película) e das propriedades da fase (por exemplo: $5 \%$ de fenilpolisiloxano). As diferenças das propriedades químicas das moléculas de uma mistura irão separar as moléculas enquanto a amostra percorre o comprimento da coluna. As moléculas saem (eludem) do cromatógrafo a gás em períodos de tempo distintos (chamado tempo de retenção), permitindo que a corrente do espectrômetro de massa capture, ionize, acelere, desvie e detecte as moléculas ionizadas separadamente. $\mathrm{O}$ espectrômetro de massa faz isso dividindo cada molécula em fragmentos ionizados e detectando estes fragmentos pela razão massa/carga. É aplicável a compostos voláteis e termicamente estáveis nas temperaturas relativamente elevadas empregadas durante o processo de separação cromatográfica (CHIARADIA et al., 2008).

\subsubsection{Importância de alguns metabólitos no desenvolvimento vegetal}

\subsection{Aminoácidos}

A literatura classifica os aminoácidos como ácidos orgânicos que possuem em sua molécula um carbono central, geralmente assimétrico, ligado covalentemente a um grupamento carboxila, um grupamento amina e um átomo de hidrogênio. Apresenta além dessas três moléculas, um radical genericamente conhecido como " $R$ ", que os diferencia, ou seja, possui uma cadeia lateral (R) diferente para cada aminoácido (MOTTA, 2007).

Existem cerca de 20 aminoácidos essenciais nas plantas, com concentrações e funções distintas. Sua função principal nas plantas é como constituintes de proteínas, bem como precursores de inúmeras substâncias reguladoras do metabolismo vegetal (alfaaminoácidos livres). O objetivo de sua aplicação nas culturas não é de suprir a necessidades das plantas quanto aos aminoácidos para a síntese protéica, mas sim como ativadores de metabolismos fisiológicos. Possuem, dentre outras funções, interação com a nutrição de plantas, aumentando a eficiência na absorção, transporte e assimilação dos

nutrientes. A quelação de cátions com aminoácidos gera moléculas sem cargas, reduzindo o efeito das forças de atração e repulsão da cutícula da folha, elevando a velocidade de absorção dos nutrientes. Estes quelatos formados por cátions e aminoácidos aumentam a 
capacidade de circulação de nutrientes pelas membranas, resultando em um importante componente da nutrição das plantas, a translocação de nutrientes pouco móveis pelos vasos do floema.

Taiz e Zeiger (2004) citam como exemplo o triptofânio, que em quantidades extremamente pequenas é precursor do mais importante hormônio de crescimento das plantas, a auxina ácido-indol-acético. Outro exemplo é do aminoácido enxofrado metionina, precursor do hormônio etileno, responsável pela maturação regular dos frutos (MOHR e SCHOPFER, 1995). Os aminoácidos tirosina e fenilanina são os precursores dos compostos fenólicos como o ácido cinâmico, o ácido cumário e flavonas, envolvidos com a defesa das plantas e dormência de sementes, e são precursores da síntese de lignina na planta, que aumenta a resistência ao acamamento (SINHA, 2004). As melhores respostas dos aminoácidos, de acordo com a literatura, têm sido em situações de estresses bióticos, como relacionados ao ataque de pragas e doenças, e abióticos, como desordens nutricionais, climáticas, deficiências hídricas ou estresses relacionados à aplicação de defensivos, em especial herbicidas, conferindo aos aminoácidos o título de agentes antiestressantes.

As plantas sintetizam e usam cerca de 300 aminoácidos diferentes, dentre eles, apenas 20 são utilizados para a síntese de proteínas. Todos os aminoácidos que fazem parte das proteínas e têm a atividade no metabolismo das plantas são L-aminoácidos. Alguns aminoácidos são preponderantes na composição das proteínas vegetais como a metionina, lisina, glicina e ácido glutâmico. Há também funções particulares nas plantas em que aminoácidos específicos estão presentes (CAÇO, 2016).

Os aminoácidos começaram a ser usados na produção agrícola em algumas situações como alternativa ao uso de fertilizantes químicos, proporcionando uma fonte de $\mathrm{N}$ de baixo custo energético para as plantas e um importante recurso para o aumento das produções. Os melhores efeitos dos aminoácidos são obtidos quando a aplicação do produto ocorre em situações climatológicas adversas, ocorrência de fitotoxicidades diversas causadas por aplicações de fitossanitários e em situações de ataques de pragas e doenças. São compostos que proporcionam aumentos na qualidade e quantidade das produções agrícolas, contribuindo para um melhor poder germinativo do pólen, melhor e mais fácil vingamento dos frutos e ainda formação e fortalecimento do sistema radicular (CAÇO, 2016).

As plantas absorvem os aminoácidos tanto pelas folhas como pelas suas raízes. Esta capacidade permite aplicações foliares ou via irrigação, propiciando um rápido 
desenvolvimento com menor consumo energético do que o necessário para o processo de síntese. O transporte de aminoácidos no xilema faz parte do processo de reciclagem de aminoácidos feito pela planta. Durante o processo, aminoácidos são enviados da parte aérea para as raízes pelo floema e reciclados no sistema radicular para a parte aérea via xilema. No percurso, quando os aminoácidos são transferidos do floema ao xilema (sistema radicular) ou do xilema ao floema (parte aérea), a composição de aminoácidos no sistema vascular muda em função da influência de processos metabólicos importantes. Isto pode envolver metabolismo do aminoácido durante seu percurso entre floema e xilema, como também a introdução de mais aminoácidos no sistema vascular, produtos dos processos de assimilação de nitrogênio (SODEK, 2002).

Dentre os principais aminoácidos, destacam-se:

A Alanina é um dos aminoácidos codificados pelo código genético, sendo, portanto, um dos componentes das proteínas dos seres vivos. É um aminoácido não essencial. Ambos os enantiómeros D-alanina e L-alanina ocorrem naturalmente, embora a D-alanina se encontre somente na parede celular de algumas bactérias (VOLLHARDT e SCORE, 1994).

Atua no reconhecimento de substratos ou reguladores alostéricos em sítios ativos ou de regulação de enzimas. Além disso, também atua como transportador dos íons amônio produzidos nos músculos para o fígado, pela aminação do piruvato em alanina, o posterior transporte desta para o fígado e a desaminação desta através da reação com o alfacetoglutarato (transaminação), formando como produtos o glutamato (que será usado no ciclo da uréia) e o piruvato novamente. Ao auxiliar a quebra do açúcar no sangue, a alanina assegura que as células humanas consigam a energia necessária para exercícios de força e resistência. Ela torna-se muito mais importante em períodos de estresse. Como um dos componentes da proteína, a alanina também ajuda a minimizar a quebra do tecido muscular e reduz a fadiga. Aumenta o tamanho do músculo e a sua força, além de prevenir a sua quebra ao estimular o volume celular e auxiliar a síntese protéica. Isso sem levar em consideração que ela melhora o tempo de recuperação do músculo após os exercícios e previne o acumulo de subprodutos nas células musculares (VOLLHARDT, 1994).

Nas plantas a alanina é importante nos processos fisiológicos em geral. É o terceiro mais importante produto do metabolismo anaeróbico, sendo resultante de altas taxas de interconversão entre os aminoácidos em que as transaminases, tais como alanina 
aminotransferase, desempenham um papel importante (SOUSA e SODEK 2002; CAÇO, 2016).

A homoserina ou isotreonina difere da serina pela inserção de um grupo metileno adicional. Produto de uma clivagem por brometo de cianogênio de um peptídeo por degradação de metionina. É um intermediário na biossíntese de três aminoácidos essenciais: metionina, treonina (um isômero da homoserina), e isoleucina. Forma-se por duas reduções de ácido aspártico via a intermediação de semi aldeído aspartato (BERG et al,. 2002).

Nas plantas, bactérias Gram negativas usam como autoindutores do Quorum Sensing, sistema de comunicação intra e interespécies de microrganismos, baseado na emissão de estímulos e respostas dependentes da densidade populacional, as acil-homoserina lactonas (AHLs - um anel de homoserina lactona que, através de uma ligação amida, liga-se a um grupamento acil, que varia conforme a espécie bacteriana considerada) (WINZER et al., 2002; SMITH et al., 2004; AMMOR et al., 2008). Este tipo de interação reflete o comportamento dos microrganismos, demonstrando a capacidade de habitar ambientes diversos, captar as informações de seu meio, comunicar-se com diferentes espécies, monitorar sua densidade populacional e principalmente regular a sua expressão gênica, controlando processos celulares como a esporulação, formação de biofilmes, expressão de fatores de virulência, produção de bacteriocinas e antibióticos e a bioluminescência. Acredita-se também que este sistema de comunicação celular desempenhe funções importantes na ecologia microbiana de alimentos, tanto na deterioração destes produtos quanto na multiplicação de patógenos e produção de toxinas (SOLA et al., 2012).

GABA, ácido gama-aminobutírico (GABA), é um neurotransmissor inibidor em todo o sistema nervoso central. É um aminoácido não protéico composto de quatro carbonos, encontrado em organismos procariontes e eucariontes. Os seus efeitos resultam principalmente da ligação ao receptor $\mathrm{GABA}_{\mathrm{A}}$ que se situa numa estrutura macromolecular em volta de um canal iônico permeável ao cloreto. A fixação do GABA ao receptor $\mathrm{GABA}_{\mathrm{A}}$ causa um aumento da condutância da membrana celular ao cloreto, que habitualmente existe em maior concentração no exterior do que no interior da célula. $\mathrm{O}$ movimento de aniões para dentro da célula aumenta a diferença de potencial entre a face externa e a interna da membrana celular e reduz a excitabilidade neuronial (BOWN e SHELP 1997). 
A função do GABA em plantas ainda não está bem definido, existe a possibilidade de estar envolvido tanto no desenvolvimento vegetal, como sinalizador de processos fisiológicos, quanto na defesa e em outras respostas ao estresse, levando a formação de embriões somáticos. Algumas evidências experimentais indicam que o Gaba se acumula em vários tecidos de plantas sob diferentes condições de estresse, tais como hipoxia, choque de temperatura, acidificação cistólica, escuro, estresse hídrico (por excesso ou falta de água) e fitohormônios, no caso o 2,4-D (ácido 2,4 diclorofenoxiacético) (SNEDDEN e FROMM, 1998).

O piroglutamato, conhecido também como ácido piroglutâmico ou 5-oxoprolina, é um derivado de aminoácido incomum no qual o grupo amino livre do ácido glutâmico é ciclizado para formar uma lactama. É o principal intermediário do ciclo $\gamma$-glutamil, que está relacionado à síntese e degradação da glutationa. Ele se acumula na deficiência de glutationa sintetase, uma doença genética autossômica recessiva clinicamente caracterizada por anemia hemolítica, acidose metabólica e sintomas neurológicos severos (PEDERZOLLI, 2008).

Weert et al. (2002) verificaram que a exsudação de alguns ácidos orgânicos como málico, piroglutâmico, succínico e fumárico e aminoácidos como ácido L-aspártico, ácido L- glutâmico, L- isoleucina, L- leucina e L- lisina por plantas de tomate, influencia a motilidade (locomoção) flagelar de Pseudomonas fluorescens. Essa aproximação de BPCV (bactérias promotoras de crescimento vegetal) beneficia as plantas, pois essas bactérias atuam na fixação biológica de nitrogênio e na biossínsetese de hormônios vegetais, como a auxina (STEENHOUDT e VANDERLEYDEN, 2000).

Segundo Boró et al. (2001), as proteínas presentes na dieta fornecem os aminoácidos necessários para o desenvolvimento e manutenção das células e tecidos do corpo humano. Como consequência da digestão das proteínas e dos aminoácidos livres são liberados os peptídeos que são cadeias com diferentes aminoácidos. Nos últimos anos tem aumentado o interesse por fragmentos específicos das proteínas que compõem a dieta que além do valor nutricional, tem atividade biológica. Ainda segundo os mesmos autores, a literatura científica chama atenção para o fato de que os peptídeos bioativos podem atravessar a parede intestinal e chegar aos tecidos periféricos via circulação sistêmica, podendo exercer funções específicas a nível local, trato intestinal e a nível sistêmico. Dentro destas atividades, os peptídeos bioativos ou funcionais podem alterar o metabolismo celular, atuar como vaso regulador, fatores de crescimento, indutores hormonais e neurotransmissores. 
O piroglutamato, segundo Carvalho e Machini (2013), está envolvido em cadeias de reação do organismo contra diversos tipos de câncer. Além disso, é considerado também reativador da memória e componente constante de suplementos alimentares como Whey Protein.

Glutamato, biossintetizado a partir de um número de aminoácidos, incluindo a ornitina e a arginina, quando aminado, o ácido glutâmico forma o importante aminoácido glutamina. O ácido glutâmico é um dos dois aminoácidos (o outro é o ácido aspártico) que possui uma carga negativa no $\mathrm{pH}$ fisiológico. Esta carga negativa torna o ácido glutâmico uma molécula bastante polar e presente no exterior de proteínas e enzimas, onde fica livre para interagir com os meios celulares aquosos que o cercam. O glutamato representa cerca de $9 \%$ dos aminoácidos das proteínas do organismo humano. É o mais frequente dos 20 aminoácidos na sequência primária das proteínas (FIB, 2014).

Tem sido utilizado no tratamento de hiperamonemia em condições de encefalopatia hepática. O cloridrato de acido glutâmico é usado para o tratamento assintomático da deficiência de acido clorídrico gástrico. O ânion carboxilato e os sais do ácido glutâmico são conhecidos como glutamatos. O glutamato é um importante neurotransmissor, que desempenha um papel chave na potenciação de longa duração e é importante para o aprendizado e a memória. O glutamato está presente em diversos alimentos. É responsável por um dos gostos básicos que constituem o paladar humano. Por esta razão, o glutamato monossódico é usado como aditivo alimentar, para realçar o sabor de alimentos. Cerca de 95\% do glutamato ingerido é absorvido rapidamente no intestino, sendo que a metade é metabolizada em $\mathrm{CO}_{2}$. Provou-se, através de pesquisas, que o glutamato aí metabolizado é o maior contribuinte para a produção da energia usada pelo intestino (SAPOLSKY, 2005).

Desempenha papel fundamental na eficiência do metabolismo do nitrogênio por ser o primeiro composto formado na assimilação desse elemento, formando as amidas glutamina e asparagina, e a partir desses, o transporte para os diferentes órgãos da planta e a síntese de clorofila e outros aminoácidos. É componente chave no crescimento e funcionamento dos meristemas (TAIZ e ZEIGER, 2004; CAÇO, 2016).

\subsection{Carboidratos (Açúcares)}

Os carboidratos (CHO) são polímeros de açúcares simples, como a glicose, com elevadas massas moleculares. Liberam e armazenam energia e também são elementos estruturais extracelulares. Considerados a fonte primária de energia para o organismo, uma 
vez que o seu catabolismo possibilita a liberação de energia química para a formação de ATP (MOTTA, 2007). São macronutrientes cujos oito maiores representantes pertencem ao reino vegetal, seja na forma de carboidrato complexo (amido e/ou celulose) ou na forma de açúcar (dissacarídeos) como a sacarose, além da glicose e da frutose, que são os monossacarídeos mais comuns da dieta (DUTRA DE OLIVEIRA e MARCHINI, 1998).

Os carboidratos, juntamente com as proteínas e lipídeos, são os constituintes principais dos organismos vivos e são classificados em mono, oligo e polissacarídeos, além de serem fonte abundante de energia. Os monossacarídeos são compostos que não podem ser hidrolisados a compostos mais simples como, por exemplo, a glicose (aldose) e frutose (cetose). Os oligossacarídeos e os polissacarídeos são formados por moléculas de monossacarídeos unidas por ligações hemiacetálicas (MALDONADE et al., 2013).

Dentre as reservas armazenadas pelas plantas, os carboidratos se destacam pela abundância, ubiquidade e multiplicidade de usos, podendo ocorrer na forma de açúcares solúveis de pequeno peso molecular, como a sacarose e os componentes da série rafinose, ou na forma de oligo e polissacarídeos, dentre os quais se destacam o amido, a inulina, os glucanos, os galactanos, os mananos e seus derivados. Das características químicas e físico-químicas desses compostos dependem o seu metabolismo e utilização pelas plantas, assim como o seu aproveitamento pelo homem. Apesar da considerável diversidade de estruturas possíveis resultantes da variação das posições das hidroxilas nas moléculas de um açúcar e das recombinações dessas unidades entre si, os tipos de carboidratos de reserva comumente encontrados em plantas são em número bastante reduzido (DIETRICHL e RIBEIRO, 1986).

Os monossacarídeos, glicose e frutose são açúcares redutores por possuírem grupo carbonílico e cetônico livres, capazes de se oxidarem na presença de agentes oxidantes em soluções alcalinas. Os dissacarídeos que não possuem essa característica sem sofrerem hidrólise da ligação glicosídica são denominados de açúcares não redutores. (SILVA et al., 2003).

Os polissacarídeos desempenham várias funções nas plantas, desde reserva e fonte de energia, composto estrutural e matéria-prima para a biossíntese de outras biomoléculas. Destacam-se o inositol e a eritrose-4-fosfato. A eritrose-4-fosfato é derivada da degradação da glicose, através da via-pentose-fosfato, sendo o precursor do ácido chiquímico, a principal via de síntese de compostos de defesa da planta contra agentes bióticos (patógenos e pragas) e abióticos (raios ultravioleta), como compostos fenólicos simples, 
lignina, taninos e flavonóides (fitoalexinas). A eritrose também é precursora da síntese de aminoácidos aromáticos, como fenilanina e tirosina (TAIZ e ZEIGER, 2004).

O amido é o mais importante polissacarídeo de reserva das plantas e, sendo insolúvel em água, pode ser estocado nas células vegetais em grande quantidade, sem afetar a pressão osmótica das mesmas. Nas plantas superiores, este composto é armazenado em plastídeos especiais, os amiloplastos, onde é formado, como já dito, principalmente a partir da sacarose translocada para esses órgãos. Ocorre na planta como uma mistura de dois glucanos estruturalmente distintos, a amilose, de cadeia linear e a amilopectina, de cadeia ramificada. As proporções desses dois componentes variam de espécie para espécie e, na mesma espécie, das condições fisiológicas ou do grau de desenvolvimento do órgão (WHISTLER e SMART, 1953; STUMPF e CONN, 1980). Existem, também, em certos órgãos de reserva, outros polissacarídeos, que podem ser armazenados fora do plasmalema, em forma solúvel nos vacúolos ou em estado altamente coloidal (MERCIER, 1985).

Os testes de açúcares são baseados em reações de óxido-redução pelo grupo hidroxílico hemiacetálico do monossacarídeo, que pode reagir com íons e formar complexos coloridos (BOBBIO e BOBBIO, 2005) ou por reações coloridas provenientes da condensação de produtos de degradação dos açúcares em ácidos fortes com vários compostos orgânicos como fenol e antrona (MALDONADE et al., 2013).

Sacarose é o mais abundante e universal dissacarídeo das plantas. Sua estabilidade estrutural e sua extrema solubilidade em água $(179 \mathrm{~g} / 1 \mathrm{OO} \mathrm{ml})$ permitem que o mesmo seja o principal carboidrato translocável das plantas (AKASAWA e OKAMOTO, 1980). Os produtos oriundos da fotossíntese são translocados na forma de sacarose para os órgãos de reserva (sementes, bulbos, tubérculos, etc.) nos quais é, geralmente, transformada em outras substâncias (amido, inulina, etc.) podendo ser, entretanto, armazenada na forma livre em algumas espécies, como Saccharum officinalis (cana-de-açúcar) e Beta vulgaris (beterraba açucareira), sendo que o suco da primeira, a garapa, contém de 15-20\% e o da segunda de 14-18\% de sacarose. Os oligossacarídeos atuam como compostos de reserva de rápida disponibilidade para a planta, além de estarem associados, juntamente com a sacarose, à crioproteção, em plantas de clima frio (LEHNINGER et al., 2006; BECK e HOPF, 1982; KELLER e MATILE, 1985).

A respiração aeróbica é comum em todos os organismos eucariotos, sendo que a respiração nas plantas apresenta algumas diferenças em relação à respiração de animais. A respiração é um processo biológico no qual compostos orgânicos reduzidos são 
mobilizados e subseqüentemente oxidados de maneira controlada. Durante a respiração, energia livre é liberada e parte é incorporada em forma de ATP, uma fonte de energia que pode ser prontamente utilizada na manutenção e no crescimento da planta. A equação geral da respiração é inversa à da fotossíntese. Do ponto de vista químico, a respiração vegetal pode ser expressa como a oxidação da molécula de 12 carbonos da sacarose e a redução de 12 moléculas de $\mathrm{H}_{2} \mathrm{O}$. A sacarose é oxidada até $\mathrm{CO}_{2}$ e $\mathrm{O}_{2}$ é reduzido para água. Parte da energia livre, liberada por esta reação, é utilizada para síntese de ATP, a função primária da respiração. Além disso, muitos intermediários envolvidos nas reações da respiração são utilizados como fontes de carbono para a síntese de muitos outros compostos de planta (por exemplo, aminoácidos). Para evitar danos na estrutura da célula, a energia resultante da oxidação de sacarose, é liberada passo a passo, mediante uma série de reações em sequência. Estas reações podem ser divididas em três fases: a Glicólise, o Ciclo do Ácido Tricarboxílico (Ciclo de Krebs) e a Cadeia de Transporte de Elétrons (ALVARENGA, 2004).

A frutose é um importante carboidrato encontrado no organismo humano e na maioria das plantas, tendo sido isolada pela primeira vez em 1847 a partir da cana-de-açúcar. É um monossacarídeo, composta por seis átomos de carbono unidos em ligações covalentes simples, apresentando grupamentos hidroxila, formados por hidrogênio e oxigênio e um grupamento carbonila, formado por ligação dupla entre o carbono e o oxigênio. A posição desse grupamento é que determinará, após a hidrólise do monossacarídeo, se ele dará origem à cetona ou aldeído. A frutose, contendo o grupamento carbonila no final da cadeia, quando hidrolisada, fornecerá cetona, e será denominada cetohexose. A glicose, por sua vez, quando hidrolisada, dará origem a aldeído, sendo chamada de aldohexose. A oxidação dos carboidratos é a principal via metabólica produtora de energia para a maioria das células não fotossintéticas, fornecendo um grama de frutose $16 \mathrm{KJ}$ de energia (NELSON et al., 2000; WANG e VAN EYS, 1981; MALTA e GUIMARÃES, 1976).

No organismo humano, a frutose é digerida, metabolizada no fígado e convertida em glicose para produção de energia (um grama de frutose produz $16 \mathrm{KJ}$ de energia). A absorção desse monossacarídeo aumenta quando ingerido sob a forma de sacarose ou combinado com a glicose. O excesso de frutose no organismo, contudo, pode causar alterações no metabolismo e potencializar o risco de resistência à insulina, situação na qual esse hormônio não exerce corretamente a sua função, tendo como consequência o aumento do teor de glicemia (BARREIROS et al., 2005). 
Inositol, também chamada de dambose, é uma substância que atua como fator de crescimento de animais e microrganismos, frequentemente utilizada como vitamina do complexo B. É um poliálcool cíclico que desempenha um importante papel como base estrutural para mensageiros secundários em células eucarióticas tais como inositol fosfatos (IPn). Pode ser encontrado em muitos alimentos como cereais e frutas. O Myo-inositol era considerado uma vitamina pertencente ao complexo $\mathrm{B}$, mas não é mais considerado porque pode ser sintetizado pelo corpo humano a partir da glicose. O inositol é base de inúmeros sinalizadores celulares e mensageiros secundários, estando envolvido em vários processos biológicos, tais como: montagem do citoesqueleto; controle da concentração intracelular do íon $\mathrm{Ca}^{2+}$; manutenção do potencial de membrana das células; modulador da atividade da insulina; quebra das gorduras; redução dos níveis de colesterol no sangue (MERCK INDEX, 2016; CLEMENTS e DARNELL, 1980).

Como fosfatidilinositol, o inositol tem a sua função primária na composição e integridade da estrutura da membrana celular. Outras funções do fosfatidilinositol ainda não foram esclarecidas. Em conjunto com a colina, pode ajudar na nutrição das células cerebrais. O Inositol é especialmente importante para as células da medula óssea, tecido do olho, e os intestinos. E ele também pode estar relacionado com o crescimento do cabelo e na transmissão de mensagens entre células neurais e o transporte de gorduras dentro das células (HOLUB, 1982).

Os canais de cálcio são fundamentais para que os neurotransmissores possam ser liberados e comecem a agir. Um dos neurotransmissores que tem maior atividade ao consumir inositol é a serotonina. Este neuroquímico está envolvido na regulação do humor e nos padrões de sono. Assim, seu papel mais importante parece ser no sistema nervoso central, onde serve para ajudar a transmitir mensagens pelas vias neurais. O inositol parece estar presente em maior concentração nas células do sistema nervoso central, incluindo as células do cérebro, células da retina, e em outras células especializadas, tais como a medula óssea e as células intestinais. Também é encontrado em concentrações elevadas no leite da mãe, conduzindo à possibilidade de uma ligação com o sistema imunológico. Esse é o motivo pelo qual o inositol, embora não seja considerado uma vitamina essencial, é tido como vital para o corpo (PARTHASARATHY e EISENBERG, 1986).

O inositol é importante para o crescimento e desenvolvimento normal das plantas, pois tem participação no metabolismo do fosfatidilinositol (PI), via de sinalização, armazenamento e transporte de auxina, biossíntese do ácido fítico (forma utilizada pelas 
plantas para armazenamento de fósforo. No entanto, não é uma fonte de fósforo nem nos humanos nem nos animais não ruminantes. A síntese da parede celular e a produção de moléculas relacionadas com o estresse. A biossíntese do inositol pode oferecer soluções para problemas agrícolas (LOEWUS e MURTHY, 2000; LOWEUS, 1990).

Galactose é um açúcar simples ou monossacarídeo. Também pode ser classificado como uma hexose simples por ser um monossacarídeo com seis carbonos. Sua fórmula molecular é partilhada com outros açúcares simples, tais como a glucose e amanose. O que os difere estruturalmente é a orientação de grupos hidroxilo específicos relativamente à restante molécula. É obtido pela hidrólise da lactose. A galactose é transformada diretamente em glicose por um processo relativamente simples. Primeiro, é fosforilada a galactose-1-fosfato por ação da cínase da galactose (com gasto de ATP), composto que, posteriormente, reage com a UDP-Glicose, originando UDP-galactose e glicose-1-fosfato. Esta reação é catalisada pela transferase da glicose-1-fosfato uridil. Posteriormente, a UDP-Galactose é isomerizada a UDP-Glicose pela 4-epimérase da UDP-Galactose. A UDP Glicose é transformada depois em glicose-1-fosfato. A galactose é importante na síntese de lactose na glândula mamária em lactação, pois nesta ocorre uma condensação entre a glicose e a UDP-Galactose, originando lactose, numa reação catalisada pela síntese da lactose. A galactose é, também, um constituinte importante dos glicolipídos, dos proteoglicanos e das glicoproteínas. A galactose não é tão doce como a glicose (BOBBIO e BOBBIO, 2005).

Em algumas algas marinhas vermelhas encontram-se heteropolissacarídeos de galactose. É a partir deste material que se faz o ágar. Devido à sua capacidade de formar géis sólidos, ele tem inúmeras aplicações, nomeadamente em laboratório e na alimentação. Seu papel biológico é energético, além de ser encontrado como componente do dissacarídeo lactose que existe no leite. É obtido pela hidrólise da lactose (MARQUES, 2015; RAVEN e JOHNSON 1995).

Glicerato, sais e ésteres do ácido glicérico, que é um ácido de açúcar natural de três carbonos é um ácido aldônico decorrente da oxidação do gliceraldeído (O’NEIL, 2006).

No processo fotorrespiratório, o ácido fosfoglicólico (2-fosfoglicolato) por ação de uma fosfoglicolato fosfatase transforma-se em glicolato que se difunde até o peroxissomo onde é oxidado a ácido glioxílico (glioxilato). O glioxilato por ação de uma aminotransferase produz duas moléculas de glicina que passam para a mitocôndria, onde se convertem em uma molécula de serina $(1 \times 3 \mathrm{C}=3 \mathrm{C})$ com liberação de $\mathrm{CO}_{2}$. A serina passa 
para o peroxissomo onde é transaminada a ácido hidroxipirúvico (hidroxipiruvato), que é reduzido a ácido glicérico. O ácido glicérico se difunde até os cloroplastos onde é fosforilado formando o 3-PGA (1x3C). Tanto o 3-PGA quanto aquelas duas moléculas de 2-fosfoglicolato formadas diretamente pela ação da rubisco (no início do ciclo) servirão de substrato para o Ciclo de Calvin (VIEIRA et al., 2010).

Treonato ou ácido treônico é o ácido aldônico derivado da treose. O isômero ácido Ltreonico é um metabólito do ácido ascórbico (vitamina C) (ENGLARD e SEIFTER, 1986).

O eritronato, composto que contêm uma unidade de sacarídeo que possui um grupo ácido carboxílico, pode ser derivado a partir de proteínas glicosiladas ou da degradação do ácido ascórbico. É formado quando o N-acetil-D-glucosamina (GlcNAc) é oxidado (JAHN et al., 1999).

A glucopiranose, forma cíclica da glucose. Neste anel, cada carbono está ligado a um grupo hidroxila lateral com exceção do quinto átomo, que se liga ao sexto átomo de carbono fora do anel, formando um grupo $\mathrm{CH}_{2} \mathrm{OH}$. É um dos principais produtos da fotossíntese e inicia a respiração celular em seres procariontes e eucariontes. No metabolismo, a glicose é uma das principais fontes de energia e fornece 4 calorias de energia por grama. A glucose hidratada (como no soro glicosado) fornece 3,4 calorias por grama (CRC, 2009).

\subsubsection{3. Ácidos orgânicos}

Ácidos orgânicos são substâncias que contém uma ou mais carboxilas em sua molécula (HART e SCHUETZ citados por PENZ et al. 1993). Nessa classificação podem ser incluídos os aminoácidos e os ácidos graxos. Em geral, quando o termo ácido orgânico é empregado na produção animal, refere-se aos ácidos fracos, de cadeia curta (C1-C7) que produzem menor quantidade de prótons por molécula ao se dissociarem. Por serem expressos logaritimicamente, uma unidade de $\mathrm{pH}$ acima do $\mathrm{pKa}$ de um ácido, indica que 90\% do ácido encontra-se na forma não dissociada e, com 2 unidades de $\mathrm{pH}$ acima do pKa, 99\% do acido estará não dissociado. Isso é particularmente importante no processo digestivo, pois na dependência do $\mathrm{pH}$ dos compartimentos digestivos haverá ação ou não do ácido em questão (DIBNER e BUTTIN, 2002).

O citrato é um ácido orgânico fraco que pode ser encontrado nos citrinos. É um ácido orgânico tricarboxílico presente na maioria das frutas, sobretudo em cítricos como o limão e a laranja. A acidez do ácido cítrico é devida aos três grupos carboxilas - $\mathrm{COOH}$ que 
podem perder um próton em soluções. Como consequência forma-se um íon citrato. Os citratos são bons controladores de pH de soluções ácidas (FIB, 2014).

Em bioquímica, é importante o seu papel como intermediário do ciclo do ácido cítrico, ou ciclo de Krebs, de forma que ocorre no metabolismo de quase todos os seres vivos. $\mathrm{O}$ ciclo de Krebs é uma das fases da respiração celular que ocorre na matriz mitocondrial e é considerada uma rota anfibólica, catabólica e anabólica (NELSON e COX, 2002).

O malato é a forma ionizada do ácido málico. Pertencente ao grupo dos ácidos carboxílicos, encontrado naturalmente em frutas como a maçã e a pêra. Muito utilizado na composição de geléias, marmeladas e bebidas de frutas. Neste último caso, o ácido confere sabor acre (azedo) às bebidas, podendo ser usado também para compor sobremesas, como sorvete, por exemplo. Na indústria farmacêutica, é utilizado na higienização e regeneração de ferimentos e queimaduras. Também serve para preservar o dulçor de alimentos e ajustar o $\mathrm{pH}$. O processo de fermentação malolática converte o ácido málico em um ácido lático mais suave. A reação que permite a produção artificial de ácido málico é obtida através do aquecimento de anidrido maleico, com corrente sob pressão. A forma natural do ácido pode ser encontrada até mesmo em nosso sangue (presente na proporção de $5 \mathrm{ppm}$ ) (JENSEN, 2007).

É um importante composto na bioquímica. No processo de fixação do carbono pela via $\mathrm{C} 4$, o malato é a fonte de $\mathrm{CO}_{2}$ no ciclo de Calvin. No ciclo de Krebs, o $(S)$-malato é um composto intermediário formado pela adição de um grupo - $\mathrm{OH}$ na face $s i$ do fumarato; ele pode também ser formado a partir do piruvato via reações anapleróticas. O malato desidrogenase catalisa a conversão reversível do malato em oxaloacetato utilizando a NAD como cofator. O malato também pode ser produzido do amido armazenado nas célulasguarda de folhas (JENSEN, 2007).

Os ácido orgânicos sofrem mudanças durante a maturação das plantas. Alcançam um máximo durante o crescimento e desenvolvimento, mas diminuem durante a estocagem e também são muito dependentes da temperatura. Durante a maturação, o malato diminui à medida que é usado para a respiração. Seu esgotamento, e de outros ácidos orgânicos, é acompanhado de um declínio da quantidade de amido e um aumento dos açúcares responsáveis pela doçura dos frutos e diminuição da acidez (ESKIN e SHAHIDI, 2015).

O fumarato é essencial na respiração de tecidos de plantas e animais. Na indústria de alimentos é empregado como agente flavorizante para dar sabor a sobremesas e proporcionar ação antioxidante. Apesar de ser encontrado naturalmente em plantas, o ácido 
fumárico é obtido de forma artificial para uma maior demanda no mercado. Pode ser obtido a partir da glicose pela ação de fungos. É o segundo ácido mais aplicado à indústria alimentícia, perdendo apenas para o ácido cítrico (DE SOUZA, 2016).

Succinato é um ácido dicarboxílico produzido como um intermediário do ciclo dos ácidos tricarboxílicos (TCA), ou como produto principal da fermentação anaeróbica por alguns microrganismos (LEE, et al., 2000), constituindo-se em um metabólito comum produzido por plantas, animais e microrganismos (ZEIKUS et al., 1999; BORGES, 2011). Considerado componente chave na obtenção de uma série de produtos comercialmente importantes, serve de matéria-prima para fabricação de muitos commodities químicos, tais como ácido adípico, surfactantes, solventes verdes, ingredientes estimulantes para crescimento de plantas, antibióticos e vitaminas (MCKINLAY et al., 2007; ZEIKUS et al., 1999). O ácido succínico e seus derivados são largamente utilizados como especialidade química para aplicações na indústria de alimentos, farmacêutica e de cosméticos (SONG e LEE, 2006).

No ciclo de Krebs, o isocitrato é convertido em succinato, enquanto que no ciclo do glioxilato, o isocitrato origina o succinato e o glioxilato. $\mathrm{O}$ succinato regenera $\mathrm{o}$ oxaloacetato e o glioxilato se condensa com acetil-CoA formando o malato. Este vai passar para o citosol, onde origina oxaloacetato, que pode ser transformado em glicose pela neoglicogênese. $\mathrm{O}$ ciclo de glioxilato desta forma permite a conversão de acetil-CoA e, portanto, de ácidos graxos, a glicose (BELTRÃO e OLIVEIRA, 2007).

Ácido glicólico foi descrito por Miltenberger (2005) como o menor $\alpha$-hidroxi ácidos (AHA). É produzido pela reação do ácido cloroacético com o hidróxido de sódio seguida por uma re-acidificação. O processo fotorrespiratório inicia-se com a ação da Rubisco sobre o $\mathrm{O}_{2}$, oxigenando a RUDP (cinco carbonos) produzindo uma molécula de PGA (três carbonos) e uma molécula de ácido glicólico (dois carbonos) que se transforma em Glicolato no cloroplasto, sendo este composto o principal substrato da fotorrespiração (VIEIRA et al, 2010). É utilizado em muitos produtos para a pele por ser de caráter natural, geralmente extraído da cana-de-açúcar e outras plantas açucareiras. É uma molécula pequena com alto poder de penetração, em relação aos outro AHAS. Os alfa-hidroxi-ácidos (AHAS) são um grupo de substâncias naturais encontradas em alguns alimentos que constituem uma família de ácidos orgânicos. Compõem os seguintes ácidos: Ácido glicólico, Ácido lático, Ácido málico, Ácido tartárico, e Ácido cítrico. Possuem em comum a hidroxila na posição alfa (ALMEIDA, 2008). 
Em elevada concentração como de 50-70\% age diminuindo a força de coesão dos queratinócitos, produção de epidermólise total e alteração dérmica, como formação de colágenos (RIGON, 2009). É um agente hidrofílico, que aumenta a hidratação e a elasticidade da pele, devido à alta capacidade de penetração, agindo na estimulação direta na produção de colágeno, elastina e mucopolissacarídeos (HENRIQUE et al., 2007).

O malonato pertence ao grupo dos ácidos dicarboxílicos. Existem duas rotas metabólicas básicas que estão envolvidas na síntese dos compostos fenólicos: a rota do ácido chiquímico e a rota do ácido malônico. A rota do ácido chiquímico participa da biossíntese da maioria dos fenóis vegetais. A rota do ácido malônico, embora seja uma fonte importante de produtos secundários fenólicos em fungos e bactérias, é menos significativa nas plantas superiores (YAMADA, 2004). A síntese malônica é um tipo de síntese utilizada em química orgânica para obter derivados mono ou disubstituídos do ácido acético. O malonato de etilo é um equivalente sintético do ácido acético (VOLLHARDT, 1994).

O malonato é um inibidor da respiração celular porque se une ao sítio da succinato desidrogenase no ciclo da ácido cítrico, mas não reage, competindo com o succinato. $\mathrm{Na}$ reação de fosforilação oxidativa, o malonato é um inibidor do complexo II que, novamente, contém succinato desidrogenase (DERVARTANIAN e VEEGE, 1964).

O gulonato ou ácido gulônico é um composto formado pela redução da extremidade da molécula de glicose em vertebrados, exceto primatas, ratos de cobaia e morcego da fruta indiano, para a fabricação do ácido ascórbico no fígado a partir da simples glicose do açúcar por meio de uma série de quatro reações, cada uma catalisada por uma enzima (LE COUTEUR, 2006).

O L-gulonato pode ter dois destinos: pode ser usado como percursor direto para a síntese do ascorbato (vitamina C), sendo que este processo não é realizado em humanos que precisam ingerir esta vitamina pela dieta; ou pode ser metabolizado a xilulose-5-P. Neste último processo, o L-gulonato é oxidado (num processo Naddependente) a 3-ceto-L-gulonato que, por sua vez, é descarboxilado a L-xilulose, composto que é reduzido (num processo NADP-dependente) a xilitol, o qual é oxidado a D-xilulose (DWORSKY e HOFFMANN-OSTENHOF, 1964; SMILEY e ASHWELL, 1961).

Ácido quínico é uma ciclitol, um poliol cíclico, e ácido ciclo-hexanocarboxílico. É um ácido cristalina encontrado em grãos de café, e outros produtos vegetais e feita 
sinteticamente pela hidrólise de ácido clorogénico. Está envolvido na percepção de acidez do café. É um constituinte dos taninos de Caesalpiniaspinos (SANTOS et al., 2011).

\subsubsection{4. Álcool}

É uma classe de compostos orgânicos que possui, na sua estrutura, um ou mais grupos de hidroxilas ("-OH") ligados a átomos de carbonos saturados. Podem ser usados como combustível, esterilizante e solvente (SAFFIOTI, 1968).

Glicerol é um tri-álcool, líquido incolor, com gosto adocicado, sem cheiro e muito viscoso, derivado de fontes naturais ou petroquímica. É uma das mais versáteis e com grande valor substâncias químicas conhecidas para o homem (BEATRIZ et al. 2011). Na natureza, o glicerol existe em vegetais (soja, mamona, babaçu, girassol, palma, algodão, coco, dendê pinhão manso) e animais em formas combinadas de glicerina com ácidos graxos. O glicerol é também um composto considerado fundamental dentro do sistema metabólico de microrganismos onde atua como precursor de numerosos compostos e como regulador de vários mecanismos bioquímicos intracelulares (LAGES et al., 1997).

Constitui o principal composto formado para regular as variações de atividade de água em ambientes altamente osmofílicos em microrganismos eucarióticos. Em humanos, participa na termo-regulação do corpo, resistência a altas temperaturas, na resistência dos músculos em atividades físicas e na resposta neural da variação da glicemia. Devido suas características físicas e químicas e ao fato de ser inócuo, o glicerol puro apresenta diferentes aplicações na indústria de cosméticos, farmacêutica, detergentes, na fabricação de resinas e aditivos e na indústria de alimentos (RIVALDI et al. 2008; WANG et al., 2001; YANG et al., 1999). Pesquisas voltadas à utilização do volume excedente de glicerol estão sendo desenvolvidas e uma aplicação promissora deste álcool seria utilizá-lo como combustível em células a combustível (GONÇALVES et al., 2009).

\subsubsection{5. Ácidos Fenólicos}

São algumas das substâncias que constituem o grupo dos compostos fenólicos. Caracterizam-se por terem um anel benzênico, um grupamento carboxílico e um ou mais grupamentos de hidroxila e/ou metoxila na molécula, conferindo propriedades antioxidantes tanto para os alimentos como para o organismo, sendo, por isso, indicados para o tratamento e prevenção do câncer, doenças cardiovasculares e outras doenças 
(KERRY e ABBEY, 1997; BRAVO, 1998; CROFT, 1998; FERGUSON e HARRIS, 1999).

Os compostos fenólicos influenciam na qualidade dos alimentos (SOARES, 2002).Vários autores afirmam que os compostos fenólicos em plantas apresentam atividades farmacológica e antinutricional e também por inibem a oxidação lipídica e a proliferação de fungos, além de participarem de processos responsáveis pela cor, adstringência e aroma em vários alimentos (NAGEM et al., 1992; GAMACHE et al., 1993; IVANOVA et al., 1997; AZIZ et al., 1998; FERNANDEZ et al., 1998; HOLLMAN e KATAN, 1998; PELEG et al., 1998).

O ácido caféico é um composto orgânico classificado como um ácido hidroxicinâmico. Possui grupos funcionais fenólicos e acrílicos. Encontra-se presente em todas as plantas, dado que é um intermediário fundamental na biossíntese da lenhina. Também é encontrado no café, no óleo de argão, no vinho (sendo este o ácido hidroxicinâmico principal) e no azeite (constituindo parte dos seus polifenóis). Apresenta propriedades antioxidantes (quer in vitro, como in vivo), bem como propriedades imunomoduladoras e anti-inflamatórias (GULÇIN, 2006; SOARES, 2002).

\subsection{Metais pesados}

Os metais pesados estão naturalmente presentes na constituição de solos e rochas, porém, têm se apresentado cada vez mais próximos da cadeia alimentar dos animais e, em especial, da do homem (FERNANDES et al., 2006).

Alguns desempenham importante papel na nutrição de plantas e animais, enquanto outros, em função das atividades antropogênicas, podem ter suas concentrações alteradas e trazer prejuízos ao homem, animais e ambiente. A aplicação de agroquímicos é uma prática comum na agricultura. Eles são utilizados principalmente com o objetivo de aumentar o suprimento de nutrientes, correção do pH do solo, através dos fertilizantes e corretivos, além de proteger as lavouras de pragas e doenças através da aplicação de agrotóxicos (KABATA-PENDIAS e MURKHERJEE, 2007).

Conforme Fernandes et al. (2006), nos solos agrícolas, a elevação dos teores de metais pesados vem sendo associada à aplicação de corretivos e adubos, utilização de água de irrigação contaminada ou de produtos como lodo de esgoto, compostos de lixo urbano e resíduos diversos de indústria ou mineração. Uma vez nos solos agrícolas, esses elementos 
podem, ainda, sob determinadas circunstâncias, ser absorvidos pelas plantas, que fazem parte da alimentação humana ou animal.

A aplicação de agroquímicos é uma prática comum na agricultura. Eles são utilizados principalmente com o objetivo de aumentar o suprimento de nutrientes, correção do pH do solo, através dos fertilizantes e corretivos, além de proteger as lavouras de pragas e doenças através da aplicação de agrotóxicos. A deficiência de micronutrientes nos solos agrícolas representa uma preocupação crescente. $\mathrm{O}$ cultivo em solos de baixa fertilidade, a calagem e o aumento da produtividade são fatores que têm favorecido o aumento das deficiências de micronutrientes. Comprovada a deficiência de micronutrientes, o agricultor procura suprir a falta destes elementos com a aplicação de fertilizantes específicos (GONÇALVES JR. et al., 2000).

Hortaliças absorvem, além dos nutrientes, os metais pesados, o que as torna modelos interessantes para os estudos dos riscos deletérios que a população humana está sujeita ao consumi-las (ZOCCHE et al., 2013).

O Chumbo $(\mathrm{Pb})$ é um metal representativo de número atômico igual a 82 e massa atômica ponderada 207,2 u. Por causa das suas características atômicas, inclui-se no grupo dos metais pesados. É bastante nocivo à boa parte dos organismos. A toxicidade do chumbo gera desde efeitos claros, ou clínicos, até efeitos sutis, ou bioquímicos. Estes últimos envolvem vários sistemas, órgãos e atividades bioquímicas. Nas crianças, os efeitos críticos atingem o sistema nervoso, enquanto que nos adultos com exposição ocupacional excessiva, ou mesmo acidental, os cuidados são com a neuropatia periférica e a nefropatia crônica. Os sistemas gastrointestinal e reprodutivo são alvo da intoxicação por chumbo (MOREIRA e MOREIRA 2004).

O Cádmio (Cd) é um subproduto da mineração do zinco e foi considerado metal pesado por meio de estudos que avaliaram a sua concentração em verduras cultivadas com adubo proveniente da compostagem de lixo orgânico. Os resultados revelaram que as hortaliças continham níveis de cádmio que representavam riscos à saúde. $\mathrm{O}$ organismo humano acumula cádmio e aos 50 anos o homem pode estar com uma carga de 20 a $30 \mathrm{mg}$, concentrando-se nos rins e paredes das artérias. A acumulação de cádmio no organismo acarreta vários riscos à saúde como problemas no metabolismo, gerando descalcificações e reumatismos. Efeitos mais graves são decorrentes da alta concentração de cádmio, que destrói o tecido testicular e as hemácias sanguíneas. Foi considerado carcinogênico e seu 
acúmulo no organismo ainda é responsável pelo desenvolvimento de hipertensão e doenças do coração (DIAS et al., 2001).

Segundo Dias et al. (2001), o cádmio pode ser adicionado ao solo através de resíduos de pneus, óleos, disposição de lixo urbano, lodo de esgoto, fertilizantes fosfatados, sendo facilmente absorvido e translocado nas plantas e tem potencial de entrar na cadeia alimentar humana.

A presença de $\mathrm{Pb}$ e $\mathrm{Cd}$ nas plantas pode induzir uma série de problemas morfológicos, fisiológicos e bioquímicos incluindo alterações na transpiração e fotossíntese, desequilíbrio no metabolismo de carboidratos e produção de tensões secundárias como estresse na nutrição, déficit de água e estresse oxidativo (WANG et al., 2015).

Portanto, para a comprovação das hipóteses lançadas neste documento e no sentido de atender aos objetivos propostos, estão listados a seguir em Material e Métodos, os procedimentos realizados nos ensaios de campo e laboratório. 


\section{MATERIAL E MÉTODOS}

Os três experimentos de campo foram realizados na Fazenda Água Limpa (FALUnB), na área de produção de hortaliças, cultivada sem o uso de insumos químicos há oito anos.

As características do solo da área experimental estão apresentadas na Tabela 2.

A FAL está localizada entre as coordenadas $15^{\circ} 56^{\prime} 00^{\prime \prime} \mathrm{S}$ (latitude) e $47^{\circ} 56^{\prime} 00^{\prime \prime} \mathrm{W}$ (longitude) a $1.080 \mathrm{~m}$ de altitude. Segundo a classificação de Köppen, o clima da região é o Aw tropical de savana, inverno seco e verão chuvoso (ROLIM et al., 2007).

Nos experimentos foi utilizada a cultivar de alface Vanda que foi desenvolvida no Brasil pela empresa Sakata. É uma variedade crespa, com plantas grandes, de coloração verde brilhante e resistente ao vírus Lettuce mosaic virus (LMV). É adaptada ao cultivo de inverno e como possui ciclo rápido e resistência à queima de bordos, está também adaptada as condições de clima tropical. Segundo Sala e Costa (2012) pode ser plantada durante todo o ano, mantendo a qualidade e manutenção no fornecimento aos mercados, além de possuir maior conservação em pós-colheita.

O delineamento experimental utilizado nos três experimentos foi em blocos ao acaso com dez tratamentos, em quatro repetições, sendo para os anos de 2012 e 2013 trabalhados os seguintes tratamentos: 1 - adubação química (controle); 2 - composto orgânico; 3 - esterco bovino; 4 - esterco ovino; 5 - esterco de aves; 6 - cama de frango; 7 adubação química + esterco bovino; 8 - adubação química + esterco ovino; 9 - adubação química + esterco de aves; 10 - adubação química + cama de frango.

No experimento de 2015, a cama de frango foi substituída pelo tratamento testemunha, sem a utilização de qualquer adubo, seja de origem química ou orgânica: 1testemunha; 2 - adubação química; 3 - composto orgânico; 4 - esterco bovino; 5 - esterco ovino; 6 - esterco de aves; 7 - adubação química + esterco bovino; 8 - adubação química + esterco ovino; 9 - adubação química + esterco de aves; 10 - adubação química + composto.

As características dos compostos e adubos orgânicos estão apresentadas na Tabela 3. 
Tabela 2. Análise do solo da área experimental utilizada para o cultivo de alface, Lactuca sativa, cv. Vanda, nos três anos de realização dos experimentos, localizada na Fazenda Água Limpa - UnB. UnB-FAV, 2016.

\begin{tabular}{|c|c|c|c|c|c|c|c|c|c|c|c|c|c|c|c|c|c|c|c|}
\hline \multirow[t]{2}{*}{ Experimento } & \multirow{2}{*}{$\begin{array}{c}\text { pH em } \\
\mathrm{H}_{2} \mathrm{O}\end{array}$} & $\mathbf{C a}$ & Mg & $\mathbf{K}$ & $\mathbf{N a}$ & $\mathbf{H}+\mathrm{Al}$ & SB & CTC & $\mathbf{V}$ & ISNa & $\mathbf{C}$ & MO & B & $\mathbf{C u}$ & $\mathbf{F e}$ & Mn & $\mathbf{Z n}$ & $\mathbf{S}$ & $\mathbf{P}$ \\
\hline & & \multicolumn{6}{|c|}{$\mathrm{cmol}_{\mathrm{c}} / \mathrm{dm}^{3}$} & \multicolumn{3}{|c|}{$\%$} & \multicolumn{2}{|c|}{$\mathrm{g} / \mathrm{kg}$} & \multicolumn{7}{|c|}{$\mathrm{mg} / \mathrm{dm}^{3}$} \\
\hline $2012 *$ & 6,0 & 2,1 & 0,7 & 0,28 & 0,04 & 3,2 & 3,12 & 6 & 49 & 0,6 & 24,0 & 41,3 & 0,5 & 0,44 & 17,1 & 10,8 & 18,6 & 3,1 & 35 \\
\hline $2013 *$ & 6,4 & 3,8 & 1,2 & 0,15 & 0,07 & 3,4 & 5,22 & 9 & 61 & 0,8 & 22,4 & 38,5 & 0,6 & 0,24 & 21,7 & 13,1 & 12,9 & 2,3 & 43 \\
\hline $2015^{*}$ & 6,7 & 4,2 & 2,4 & 0,32 & 0,06 & 2,9 & 6,98 & 9 & 70 & 0,7 & 17,6 & 33,9 & 0,6 & 0,37 & 26,1 & 13,9 & 16,3 & 7,1 & 67 \\
\hline
\end{tabular}

*Amostra composta de $1 \mathrm{~kg}$ de solo enviada ao Laboratório de Análise de Solo-Soloquímica, Brasília-DF. 
Tabela 3. Composição química dos compostos e adubos orgânicos utilizados no cultivo de alface, Lactuca sativa, cv. Vanda, na área experimental da Fazenda Água Limpa - UnB, nos anos de 2013, 2014 e 2015. Brasília: UnB-FAV, 2016.

\begin{tabular}{lcccccccccccccc}
\hline \multicolumn{1}{c}{ Parâmetros } & \multicolumn{1}{c}{ Composto Orgânico* } & \multicolumn{3}{c}{ Esterco Bovino* } & \multicolumn{3}{c}{ Esterco Ovino* } & \multicolumn{3}{c}{ Esterco de Aves* } & Cama de Frango* \\
& 2012 & 2013 & 2015 & 2012 & 2013 & 2015 & 2012 & 2013 & 2015 & 2012 & 2013 & 2015 & 2012 & 2013 \\
\hline pH & 6,9 & 7,0 & 6,4 & 8,4 & 8,6 & 8,8 & 7,1 & 7,8 & 7,4 & 9,0 & 8,8 & 8,6 & 8,9 & 8,3 \\
Umidade a 65ㄷ & 34,4 & 33,2 & 38,3 & 41,3 & 32,0 & 38,6 & 36,0 & 22,6 & 25,8 & 46,2 & 37,5 & 42,7 & 55,3 & 46,4 \\
Umidade a $110^{\circ} \mathrm{C}$ & 0,2 & 0,42 & 0,9 & 3,0 & 0,5 & 2,0 & 0,2 & 0,3 & 0,8 & 3,0 & 0,64 & 1,0 & 2,0 & 1,5 \\
Matéria orgânica (MO)\% & 29,3 & 26,7 & 32,5 & 32,1 & 29,8 & 34,3 & 32,7 & 34,8 & 32,6 & 31,1 & 24,4 & 34,5 & 41,4 & 46,2 \\
Nitrogênio total (N)\% & 0,49 & 0,53 & 0,61 & 2,0 & 1,53 & 1,82 & 1,60 & 2,50 & 1,94 & 3,22 & 3,46 & 3,64 & 3,00 & 3,20 \\
Fósforo total (P)\% & 0,45 & 0,48 & 0,42 & 1,28 & 1,1 & 1,39 & 1,18 & 1,84 & 1,27 & 2,26 & 2,02 & 2,45 & 1,29 & 1,46 \\
Potássio total (K)\% & 6,95 & 3,46 & 5,58 & 2,92 & 2,28 & 1,93 & 2,14 & 2,72 & 3,08 & 3,00 & 2,36 & 3,22 & 2,54 & 2,72 \\
Cálcio (Ca)\% & 1,05 & 1,23 & 1,32 & 8,55 & 6,67 & 7,57 & 1,94 & 2,42 & 3,41 & 17,1 & 16,74 & 17,4 & 7,32 & 7,74 \\
Magnésio (Mg)\% & 0,28 & 0,32 & 0,36 & 1,03 & 0,8 & 1,38 & 0,79 & 0,57 & 0,83 & 0,89 & 0,73 & 0,98 & 0,69 & 0,84 \\
Enxofre (S)\% & 0,26 & 0,38 & 0,29 & 0,58 & 0,45 & 0,63 & 0,04 & 0,76 & 0,53 & 0,69 & 0,51 & 0,73 & 0,56 & 0,63 \\
Boro (B) ppm & 23,7 & 21,3 & 26,9 & 18 & 14 & 22 & 29,6 & 24,3 & 31,2 & 36,5 & 46,5 & 39,4 & 40,9 & 38,6 \\
Cobre (Cu) ppm & 20,1 & 23,4 & 25,2 & 88 & 68,8 & 73 & 63,8 & 41,9 & 59,3 & 69,6 & 71,5 & 73,2 & 82,3 & 76,1 \\
Ferro (Fe) ppm & 12658 & 13751 & 13298 & 278 & 244 & 256 & 138 & 268 & 321 & 272 & 236 & 277 & 1821 & 1436 \\
Manganês (Mn) ppm & 91 & 109 & 112 & 426 & 332 & 412 & 330 & 374 & 406 & 583 & 464 & 432 & 223 & 238 \\
Zinco (Zn) ppm & 71 & 86 & 92 & 362 & 282 & 322 & 239 & 296 & 291 & 631 & 586 & 602 & 235 & 268 \\
\hline & & & & & & & & & & &
\end{tabular}

*As amostras compostas de $1 \mathrm{~kg}$ de material foram encaminhadas para o Laboratório de Análise de Solo - Soloquímica, Brasília-DF, quando da montagem dos experimentos. 
As áreas experimentais, em cada ano, foram divididas em quatro canteiros com $60 \mathrm{~m}$ de comprimento e $1 \mathrm{~m}$ de largura que foram por sua vez subdivididos em dez parcelas de $6 \mathrm{~m}$ de comprimento, resultando em 40 parcelas de $6 \mathrm{~m}^{2}$ em cada experimento. $\mathrm{O}$ espaçamento entre as plantas foi de $0,3 \times 0,3 \mathrm{~m}$.

Nos três anos, o solo foi corrigido com 200g. $\mathrm{m}^{-2}$ de calcário e $200 \mathrm{~g} \cdot \mathrm{m}^{-2}$ de Yoorin , conforme limites estabelecidos na Instrução Normativa 46 (MAPA, 2011).

$\mathrm{Na}$ adubação de plantio, as proporções dos fertilizantes utilizadas foram baseadas nas orientações presentes em Souza e Resende (2006): $3 \mathrm{~kg} \cdot \mathrm{m}^{-2}$ para os estercos bovino, ovino e cama de frango; $1,5 \mathrm{~kg} \cdot \mathrm{m}^{-2}$ para o esterco de aves e $0,5 \mathrm{~kg} \cdot \mathrm{m}^{-2}$ para o composto orgânico para os três anos.

Para o tratamento com adubação química, conforme Ribeiro et al. (1999), os seguintes produtos e quantidades foram utilizados no plantio: Uréia - 40kg.ha ${ }^{-1}$, para os três anos de experimento; Cloreto de potássio: 35, 20e 40kg.ha ${ }^{-1}$ para os anos de 2012, 2013 e 2015, respectivamente; Superfosfato simples: 550, 450 e 300kg.ha ${ }^{-1}$ para os anos de 2012, 2013 e 2015, respectivamente,de acordo com análise de solo (Tabela 2).

As adubações de cobertura foram realizadas aos 30 e 45 dias após o plantio nos três experimentos. Para os adubos orgânicos foram utilizadas as seguintes quantidade: $2 \mathrm{~kg} \cdot \mathrm{m}^{-2}$ para os estercos bovino, ovino e cama de frango; $0,5 \mathrm{~kg} \cdot \mathrm{m}^{-2}$ para o esterco de aves; $0,5 \mathrm{~kg} \cdot \mathrm{m}^{-2}$ para o composto orgânico.

$\mathrm{Na}$ adubação de cobertura, para os adubos químicos foram utilizadas as seguintes quantidades: Uréia - 120kg.ha- ${ }^{-1}$, dividida em duas aplicações; Cloreto de potássio: 70, 40 e 80 kg.ha ${ }^{-1}$, dividida em duas aplicações, para os anos de 2012, 2013 e 2015, respectivamente, para o tratamento com adubação química. Os fertilizantes foram incorporados ao solo.

Para cada um dos experimentos, foi realizada formação de mudas em bandejas de isopor de 288 células, 30 dias antes do transplantio.

O primeiro experimento teve a distribuição de adubos realizada no dia 01 de agosto, plantio em 02 de agosto e colheita em 04 de outubro de 2012. As condições climáticas do período estão descritas na Tabela 4. 
Tabela 4. Dados agroclimatológicos médios e precipitação total no período de agosto a outubro de 2012 na área experimental da Fazenda Água Limpa - UnB. Brasília: UnBFAV, 2016.

\begin{tabular}{|c|c|c|c|c|c|c|c|c|c|}
\hline MÊS & $\begin{array}{c}\text { Prec. } \\
\text { Mm }\end{array}$ & $\begin{array}{c}\text { Rad.global } \\
\mathrm{MJ} / \mathrm{m}^{2} \mathrm{~d}\end{array}$ & $\begin{array}{l}\text { Vento } \\
\text { méd. }\end{array}$ & $\begin{array}{c}\text { Tmed } \\
{ }^{\circ} \mathrm{C}\end{array}$ & $\begin{array}{c}\text { Tmáx } \\
{ }^{\circ} \mathrm{C}\end{array}$ & $\begin{array}{c}\mathrm{T} \text { min } \\
{ }^{\circ} \mathrm{C}\end{array}$ & $\begin{array}{c}\text { URméd } \\
\%\end{array}$ & $\begin{array}{c}\text { URmax. } \\
\%\end{array}$ & $\begin{array}{c}\text { URmin. } \\
\%\end{array}$ \\
\hline Agosto & 0,0 & 18,48 & 1,50 & 18,61 & 26,90 & 26,90 & 56,36 & 86,07 & 30,01 \\
\hline Setembro & 26,4 & 19,50 & 1,08 & 21,53 & 30,70 & 30,70 & 55,14 & 87,20 & 27,92 \\
\hline Outubro & 74,4 & 20,47 & 1,08 & 22,20 & 31,15 & 31,15 & 61,93 & 91,79 & 31,27 \\
\hline
\end{tabular}

FONTE: FAL-FAV, UnB

O segundo experimento teve a distribuição de adubos realizada no dia 14 de fevereiro, plantio em 15 de fevereiro e colheita em 12 de abril de 2013. As condições climáticas do período estão descritas na Tabela 5.

Tabela 5. Dados agroclimatológicos médiose precipitação total no período de fevereiro a abril de 2013 na área experimental da Fazenda Água Limpa - UnB. Brasília: UnB-FAV, 2016.

\begin{tabular}{|c|c|c|c|c|c|c|c|c|c|}
\hline MÊS & $\begin{array}{l}\text { Prec. } \\
\text { Mm }\end{array}$ & $\begin{array}{c}\text { Rad.global } \\
\mathrm{MJ} / \mathrm{m}^{2} \mathrm{~d}\end{array}$ & $\begin{array}{l}\text { Vento } \\
\text { méd. }\end{array}$ & $\begin{array}{l}\text { Tmed } \\
{ }^{\circ} \mathrm{C}\end{array}$ & $\begin{array}{l}\text { Tmáx } \\
{ }^{\circ} \mathrm{C}\end{array}$ & $\begin{array}{c}\mathbf{T} \min \\
{ }^{\circ} \mathbf{C}\end{array}$ & $\begin{array}{c}\text { URméd } \\
\%\end{array}$ & $\begin{array}{c}\text { URmax. } \\
\%\end{array}$ & $\begin{array}{c}\text { URmin. } \\
\%\end{array}$ \\
\hline Fevereiro & 128,2 & 19,07 & 0,89 & 21,83 & 29,32 & 15,74 & 76,82 & 98,15 & 44,80 \\
\hline Março & 196,2 & 15,70 & 0,84 & 21,72 & 28,50 & 17,13 & 82,78 & 98,63 & 50,05 \\
\hline Abril & 132,8 & 14,9 & 0,7 & 20,0 & 27,1 & 14,5 & 82,7 & 98,9 & 52,6 \\
\hline
\end{tabular}

FONTE: FAL-FAV, UnB

O terceiro experimento teve a distribuição de adubos e o plantio realizados no dia 25 de março e colheita em 01 de junho de 2015. Neste experimento a cama de frango foi substituída por um tratamento testemunha sem a adição de fertilizantes químicos ou orgânicos. As condições climáticas do período estão descritas na Tabela 6. 
Tabela 6. Dados agroclimatológicos médios e precipitação total no período de março a junho de 2015 na área experimental da Fazenda Água Limpa - UnB. Brasília: UnB-FAV, 2016.

\begin{tabular}{cccccccccc}
\hline MÊS & Prec. & Rad.global & Vento & Tmed & Tmáx & Tmin & URméd. & URmax. & URmin. \\
$\mathbf{2 0 1 3}$ & $\mathbf{M m}$ & $\mathbf{M J} / \mathbf{m}^{\mathbf{2}} \mathbf{d}$ & $\mathbf{m e ́ d .}$ & ${ }^{\mathbf{0}} \mathbf{C}$ & ${ }^{\mathbf{}} \mathbf{C}$ & ${ }^{\mathbf{o}} \mathbf{C}$ & $\mathbf{\%}$ & $\mathbf{\%}$ & $\boldsymbol{\%}$ \\
\hline Março & 300,2 & 12,2 & nd & 20,4 & 27,0 & 16,2 & 87,9 & 99,0 & 58,6 \\
Abril & 129,2 & 13,6 & nd & 21,2 & 28,1 & 16,9 & 85,9 & 99,0 & 54,9 \\
Maio & 23,8 & 13,3 & nd & 18,8 & 25,7 & 13,0 & 84,0 & 99,0 & 55,8 \\
Junho & 0,0 & 14,1 & nd & 17,5 & 25,7 & 10,2 & 77,6 & 98,6 & 45,3 \\
\hline
\end{tabular}

FONTE: FAL-FAV, UnB

Não houve necessidade de realizar o manejo de artrópodes ou fitopatógenos. Porém, foi realizado o manejo de plantas espontâneas por meio da capina 21 dias após o transplantio e em intervalos de 15 dias até a colheita do experimento.

Após a colheita, as plantas foram transportadas em caixas plásticas, amostras foram retiradas para avaliação do desempenho agronômico e análises laboratoriais, com metodologias específicas para cada caso, descritas a seguir.

\subsection{Avaliação de características agronômicas das plantas de alface}

As características agronômicas avaliadas foram massa fresca, massa seca e produtividade da planta de alface cv. Vanda. Foram colhidos 15 pés de alface ao acaso de cada parcela, totalizando 60 pés de alface avaliados por tratamento e 600 plantas avaliadas em cada experimento. O primeiro experimento foi avaliado com 65 dias, o segundo com 60 dias e o terceiro 68 dias após o transplantio. Os pés de alface foram submetidos à limpeza da saia e toalete (FILGUEIRA, 2003), pesados em balança de precisão para a avaliação de massa fresca. As análises de massa fresca foram realizadas em outubro de 2012, abril de 2013 e junho de 2015.

Logo após, foram pesados $200 \mathrm{~g}$ para avaliação de massa seca. As amostras foram secas em estufa com ventilação forçada por 72 horas a $60^{\circ} \mathrm{C}$ de temperatura (DÔRES e CASALI, 2007). As análises de massa seca foram realizadas em outubro de 2012e abril de 2013.

Os dados coletados foram submetidos à análise de variância e as médias comparadas pelo teste de Tukey ao nível de 5\% de probabilidade. 


\subsection{Avaliação da presença de metais pesados e microrganismos}

Para a detecção de Cádmio $(\mathrm{Cd})$ e Chumbo $(\mathrm{Pb})$, foi coletada uma amostra composta de $200 \mathrm{~g}$ de folhas de cada parcela, nos períodos de inverno do ano de 2012 e verão do ano de 2013, na colheita do experimento.

As amostras foram secas em estufa com ventilação forçada por 72 horas a $60^{\circ} \mathrm{C}$ de temperatura e enviadas ao Laboratório Campo Análises Agrícolas e Ambientais, localizado em Paracatu-MG, para quantificação dos teores de $\mathrm{Cd}$ e $\mathrm{Pb}$, de acordo com metodologias e procedimentos analíticos descritos no Manual de Métodos de Análise de Solo (EMBRAPA, 1997).

Os resultados foram interpretados de acordo com o Regulamento Técnico do Ministério da Saúde, Secretaria de Vigilância Sanitária - SVS/MS (BRASIL, 1998).

Para avaliar a presença de Coliformes termotolerantes e Salmonella spp., após a colheita das plantas de alface, no período do verão do ano 2015, 68 dias após o transplantio, foi retirada, com luvas de látex, uma folha ao acaso por parcela e posteriormente foi realizado um mix de $200 \mathrm{~g}$ de folhas para gerar uma amostra de cada tratamento. As folhas foram acondicionadas em sacos plásticos do tipo ziploc ${ }^{\circ}$ e refrigeradas imediatamente para posterior análise. Os sacos plásticos contendo as amostras foram transportados ao laboratório em caixas térmicas contendo cubos de gelo e aí mantidos até o início das análises. O período decorrido entre a coleta das amostras de alface e o início das análises foi, no máximo, de duas horas.

A análise microbiológica foi realizada no Laboratório de Análise Microbiológica de Alimentos (LAMAL) da FAV-UnB para determinação da presença de Salmonella sp. e de coliformes termotolerantes (indicadores de contaminação fecal).

A fim de realizar a quantificação de coliformes termotolerantes nas amostras coletadas, foi utilizado o método tradicional de tubos múltiplos, em conformidade com a legislação apresentada por Silva et al. (2010) e MAPA (2003).

O método dos tubos múltiplos é realizado em duas etapas: na primeira, chamada fase presuntiva, a amostra é inoculada em caldo lauril sulfato de sódio, que inibe a microbiota acompanhante e, ao mesmo tempo é um meio de enriquecimento para bactérias do grupo dos coliformes. Bactérias deste grupo causam turvação no meio com formação de gás, detectado em tubos de Duhran após 48 horas de incubação a $35 \pm 2^{\circ} \mathrm{C}$. 
A segunda etapa, chamada fase confirmativa, é realizada através da inoculação de alçadas dos caldos lauril positivos em caldos seletivos para Escherichia coli (EC). Após incubação a $44,5^{\circ} \mathrm{C}$, durante 24 horas, ocorre turvação do caldo EC com formação de gás, quando positivos para coliformes fecais, segundo Rompré et al. (2002).

A quantificação de coliformes termotolerantes foi realizada através de um método simplificado de aproximação, denominado "Número Mais Provável" (NMP), sendo o resultado expresso em NMP por $100 \mathrm{~mL}$. Depois da leitura, os valores são comparados com a tabela do NMP (ASSOCIATION OF OFFICIAL ANALYTICAL CHEMISTSBacteriological Analytical Manual, 1984) correspondente à técnica utilizada. O arranjo de número de tubos positivos das três diluições é transposto para tabelas estatísticas que informam o NMP para as diferentes combinações de tubos positivos e que também incluem os limites de confiança dos números mais prováveis dos microrganismos pesquisados em função da tabela em questão (Anexo1). Os intervalos de confiança $95 \%$ constantes das tabelas de NMP oferecem a informação de que, em pelo menos $95 \%$ das vezes, há a chance da concentração real do microrganismo alvo estar incluído no intervalo de confiança calculado para cada arranjo de tubos positivos.

A técnica utilizada para detecção de Salmonella spp foi o método recomendado pela legislação, segundo Silva (2010) e MAPA (2003). É um método de cultura clássico dividido em cinco etapas sequenciais: 1) o pré-enriquecimento em caldo não seletivo para restaurar células injuriadas a uma condição fisiológica estável; 2) enriquecimento seletivo, no qual a amostra é novamente colocada em caldo de cultivo contendo reagentes inibitórios que permite a multiplicação de Salmonella spp, enquanto restringe a proliferação da maioria das outras bactérias; 3) semeadura em meios sólidos seletivos que restringem a multiplicação de outras bactérias que não Salmonella e; 4) testes bioquímicos, que fornecem dados fenotípicos da cultura isolada; 5) sorotipagem para caracterização antigênica, que é o passo definitivo e provê a identificação especifica da cultura isolada (SILVA e EIROA; 1993; BAILEY, et al., 1991).

$\mathrm{Na}$ primeira etapa a amostra de $25 \mathrm{~g}$ de alface foi incubada a aproximadamente $36 \pm$ $1{ }^{\circ} \mathrm{C}$ de 16 a 20 horas em $225 \mathrm{ml}$ de diluente especifico para a Salmonella, solução salina peptonada tamponada (tampão fosfato). Essa primeira etapa não é seletiva, serve para recuperar as células estressadas pelo processamento do alimento, ativando seu metabolismo, seu desenvolvimento e multiplicação. 
$\mathrm{Na}$ segunda etapa, a amostra passou pelo enriquecimento seletivo através dos meios de cultura Rappaport Vassiliadis (RVS) e o Caldo Tetrationato (TT) incubados à temperatura de $41 \pm 0,5^{\circ} \mathrm{C}$ durante 24 horas, que viabiliza o crescimento da Salmonella e inviabilize o crescimento de microrganismos interferentes.

Restabelecidas, as células previamente selecionadas, passam para a terceira etapa, a de isolamento e seleção de colônias de Salmonella para serem cultivadas no meio sólido Ágar verde brilhante (BPLS).

A quarta etapa é realizada quando o teste das placas indica suspeita de Salmonella, a identificação bioquímica do patógeno, é baseando-se na evidenciação das propriedades fisiológicas e metabólicas das culturas suspeitas.

Na quinta etapa, é utilizado o método sorológico, baseado na reação de anticorpos com a bactéria. O resultado é baseado na reação entre um antígeno (Salmonella) e um anticorpo, obtido de soro de coelho. A presença do antígeno, para qual o anticorpo foi produzido no coelho, é indicada pela formação de grumos em placa quando misturado a um meio líquido que apresente as células bacterianas, o que ocorre quase que instantaneamente, sendo este um método muito sensível e extremamente seletivo. Se a sorologia for negativa, não há formação de grumos visíveis na placa.

No presente trabalho, a quarta e quinta etapa não foram realizadas pois na terceira etapa não foram isoladas colônias de Salmonella.

\subsection{Quantificação do teor de clorofilas $a$ e $b$, clorofila total $(a+b)$ e carotenóides totais}

Para a análise de pigmentos fotossintéticos foi utilizada a metodologia descrita por Wellburn (1994).

Foram coletadas uma folha de três plantas diferentes por parcela, ao acaso, totalizando três folhas por parcela e 12 folhas por tratamento, no inverno de 2012. Um disco de $0,01027 \mathrm{~cm}^{2}$ foi retirado do centro do limbo de cada folha e colocado em um tubo de microcentrífuga (Eppendorff) âmbar contendo $2 \mathrm{ml}$ de DMF (N, N-dimetilformamida HCON (CH3)2 - Fabricante: Vetec () .

Os tubos foram imediatamente envolvidos em papel de alumínio e dispostos em caixas de isopor contendo nitrogênio líquido. Após a coleta, as amostras foram mantidas a $4^{\circ} \mathrm{C}$ por $24 \mathrm{~h}$ em geladeira. Ao término desse tempo foi determinada a absorbância das amostras nos comprimentos de onda de $663,8 \mathrm{~nm}, 646,8 \mathrm{~nm}$ e $480 \mathrm{~nm}$, em espectrofotômetro (ThermoSpectronic ${ }^{\circledR}$ modelo Genesys 2), para determinação das clorofilas $a$ e $b$ e dos 
carotenóides totais, respectivamente. Com os valores de absorbância obtidos, as concentrações de clorofila $a$ e $b$, clorofila total $(a+b)$ e carotenóides totais foram calculadas pelas fórmulas descritas por Wellburn (1994):

Chlor A = (12 XA663.8 - 3,11 XA646.8) X volume.

Chlor B = (20,78 XA646.8 - 4,88 XA663.8) X volume.

Carotenóides $=(1000$ XA480- 1,12 XChlor A - 34,07 XChlor B)/245) X 2.

As análises das amostras foram realizadas no Laboratório de Fisiologia Vegetal, no Instituto de Biologia da Universidade de Brasília, no período de outubro de 2012 a fevereiro de 2013.

Os resultados foram submetidos à análise de variância e as médias comparadas pelo teste de Tukey ao nível de 5\% de probabilidade.

\subsection{Perfil metabólico de plantas de alface}

Para determinação do perfil metabólico, foram coletadas três folhas por parcela, ao acaso, que foram imediatamente envolvidas em papel de alumínio e dispostas em caixas de isopor contendo nitrogênio líquido. As folhas foram liofilizadas e congeladas a $-80^{\circ} \mathrm{C}$. As coletas foram realizadas no período de inverno do ano de 2012, 65 dias após o transplantio das mudas, e verão do ano de 2013, 60 dias após o transplantio das mudas.

A preparação da amostra foi realizada pelo protocolo descrito por Lisec et al. (2006).

Pesou-se 10mg da amostra liofilizada. Adicionou-se $1,4 \mathrm{~mL}$ de metanol e $60 \mu \mathrm{l}$ de Ribitol (Adonitol). Colocou-se no vortex por $10 \mathrm{~s}$. Agitou-se durante 10 minutos a $70^{\circ} \mathrm{C}$ no termo misturador a $950 \mathrm{rpm}$. Centrifugou-se por 10 minutos com força de aceleração de 10.000gravidade. Transferiu-se $750 \mu 1$ do sobrenadante para um novo frasco. Adicionou-se $375 \mu 1$ de clorofórmio e $750 \mu \mathrm{l}$ de $\mathrm{MQH}_{2} \mathrm{O}$. Colocou-se no vortex durante 10 segundos. Centrifugou-se por 10 minutos com força de aceleração de 2.200gravidade. Transferiu-se $200 \mu \mathrm{l}$ da fase superior (fase polar) para um novo tubo de $1.5 \mathrm{~mL}$. Colocou-se no speedvac a $30^{\circ} \mathrm{C}$ por 30 minutos. Adicionou-se $40 \mu 1$ de reagente cloridrato de metoxiamina aos tubos. Colocou-se no vortex por 10 segundos. Agitou-se os frascos no shakingdri-block durante 2 horas a $37^{\circ} \mathrm{C}$. Adicionou-se $70 \mu \mathrm{l}$ de reagente MSTFA para as alíquotas de amostra. Colocou-se no vortex 10 segundos. Agitou-se no shakingdri-block durante 30 minutos a $37^{\circ} \mathrm{C}$. Transferiu-se $100 \mu 1$ para frascos de vidro adequados para análise por GCMS. Os frascos foram colocados no GC-MS para detectar as moléculas ionizadas.

A extração restante foi mantida congelada em $-80^{\circ} \mathrm{C}$ como reserva. 
Os cromatogramas obtidos tiveram a linha de base corrigidas com o software metAlign (Lommen, 2009) e a altura dos picos de massa foram normalizados para o padrão interno (ribitol).

As 80 amostras, em triplicata, totalizando 240 amostras, foram preparadas para análise entre os meses de fevereiro e maio de 2014. Após o preparo, foi trabalhada a calibração do equipamento GC-MS, realizada nos meses junho e início de julho, através de testes com as amostras preparadas.

As amostras foram analisadas no período de julho a outubro de 2014 , de cinco em cinco, de acordo com a disponibilidade do equipamento. De novembro de 2014 a fevereiro de 2015 foi realizada a identificação dos compostos encontrados, através da comparação com bibliotecas espectrais. 


\section{RESULTADOS E DISCUSSÃO}

\subsection{Desempenho agronômico das plantas de alface}

Considerando a fertilização orgânica e mineral aplicada, verificou-se que para os parâmetros de massa fresca, massa seca e produtividade da alface cv. Vanda não houve diferença estatística entre os tratamentos nos experimentos realizados em 2012 e 2013. Além disso, não foi observada diferença estatística entre as duas épocas de cultivo. Observou-se, no entanto, ação sinergística da mistura fertilizante químico e cama de frango, com produtividade $44 \%$ superior à observada no tratamento com fertilização química e 7,27\% superior ao tratamento com cama de frango. No período de inverno, os fertilizantes orgânicos cuja base foram estercos animais proporcionaram em média pés de alface com $306 \mathrm{~g}$, enquanto o fertilizante químico resultou em pés de $243 \mathrm{~g}$. Foi observada variação na massa fresca, da maior para a menor, de 146,2g (Tabela7).

No ano de 2013, período de verão, verificou-se maior precipitação pluviométrica comparada àquela observada no período de inverno de 2012 (Tabelas 4 e 5), o que provavelmente contribuiu para produção de massa fresca superior em quase todos os tratamentos, principalmente naqueles que receberam fertilização com estercos animais. Os fertilizantes orgânicos cuja base foram estercos animais proporcionaram em média pés de alface com $321,85 \mathrm{~g}$, enquanto o fertilizante químico resultou em pés de $233 \mathrm{~g}$. Foi observada variação na massa fresca, da maior para a menor, de 197,2g. Não foi observada ação sinergística da mistura de fertilizantes neste caso específico.

No terceiro experimento, realizado no verão de 2015 , houve substituição da cama de frango por um tratamento controle, sem aplicação de qualquer tipo de fertilizante, no plantio ou em cobertura. Verificou-se diferença estatística entre os tratamentos (Tabela 8), sendo que o tratamento com esterco de aves apresentou o melhor resultado de massa fresca e produtividade, diferindo estatisticamente dos tratamentos controle e fertilização química, com massa fresca de 371,5g; 187,5g e 198,5g, respectivamente. Porém, não diferiu estatisticamente dos demais tratamentos de fertilização orgânica e dos tratamentos em mistura. 
Os fertilizantes orgânicos cuja base foram estercos animais proporcionaram em média pés de alface com 293,53g, enquanto o fertilizante químico resultou em pés com massa fresca de 187,5g. Foi observada variação na massa fresca, da maior para a menor, de 184g.

Quanto à massa seca, não houve diferença estatística entre os tratamentos na época e entre as épocas de avaliação, considerando os experimentos de 2012 e 2013. 
Tabela 7. Massa fresca (g) (MF), massa seca (g) (MS) e produtividade (kg.m ${ }^{-2}$ ) de plantas de alface Lactuca sativa, cv. Vanda, sob fertilização orgânica e mineral no período de inverno do ano de 2012 e verão do ano de 2013 no Distrito Federal. UnB-FAV, 2016.

\begin{tabular}{lcccccc}
\hline \multicolumn{1}{c}{ Tratamento* } & MF (inverno) & $\begin{array}{c}\mathbf{2 0 1 2} \\
\text { MS (inverno) }\end{array}$ & Produtividade & MF (verão) & $\begin{array}{c}\text { MS (verão) } \\
\text { Produtividade }\end{array}$ \\
\hline Químico & $243,4 \mathrm{a}$ & $13,33 \mathrm{a}$ & $2,704 \mathrm{a}$ & $233,0 \mathrm{a}$ & $22,64 \mathrm{a}$ & $2,588 \mathrm{a}$ \\
Composto orgânico & $206,4 \mathrm{a}$ & $16,00 \mathrm{a}$ & $2,293 \mathrm{a}$ & $227,5 \mathrm{a}$ & $23,91 \mathrm{a}$ & $2,527 \mathrm{a}$ \\
Esterco bovino & $328,0 \mathrm{a}$ & $22,66 \mathrm{a}$ & $3,644 \mathrm{a}$ & $304,7 \mathrm{a}$ & $24,74 \mathrm{a}$ & $3,385 \mathrm{a}$ \\
Esterco ovino & $331,4 \mathrm{a}$ & $17,33 \mathrm{a}$ & $3,681 \mathrm{a}$ & $258,8 \mathrm{a}$ & $22,42 \mathrm{a}$ & $2,875 \mathrm{a}$ \\
Esterco de aves & $238,2 \mathrm{a}$ & $26,00 \mathrm{a}$ & $2,646 \mathrm{a}$ & $299,2 \mathrm{a}$ & $22,54 \mathrm{a}$ & $3,324 \mathrm{a}$ \\
Cama de frango & $327,0 \mathrm{a}$ & $22,66 \mathrm{a}$ & $3,632 \mathrm{a}$ & $424,7 \mathrm{a}$ & $19,62 \mathrm{a}$ & $4,718 \mathrm{a}$ \\
Químico + esterco bovino & $264,2 \mathrm{a}$ & $12,66 \mathrm{a}$ & $2,935 \mathrm{a}$ & $301,6 \mathrm{a}$ & $23,14 \mathrm{a}$ & $3,350 \mathrm{a}$ \\
Químico + esterco ovino & $264,0 \mathrm{a}$ & $15,33 \mathrm{a}$ & $2,933 \mathrm{a}$ & $330,2 \mathrm{a}$ & $26,00 \mathrm{a}$ & $3,668 \mathrm{a}$ \\
Químico + esterco de aves & $236,4 \mathrm{a}$ & $18,66 \mathrm{a}$ & $2,626 \mathrm{a}$ & $297,2 \mathrm{a}$ & $29,80 \mathrm{a}$ & $3,301 \mathrm{a}$ \\
Químico + cama de frango & $352,6 \mathrm{a}$ & $25,33 \mathrm{a}$ & $3,917 \mathrm{a}$ & $367,3 \mathrm{a}$ & $25,53 \mathrm{a}$ & $4,080 \mathrm{a}$ \\
\hline CV(\%) & 29 & 36 & 29 & 27 & 32 & 27 \\
\hline
\end{tabular}

Médias seguidas pela mesma letra nas colunas, não diferem estatisticamente entre si, pelo teste de Tukey a 5\% de probabilidade. Químico= plantio: 40kg.ha-1 de uréia; 35, 20 kg.ha ${ }^{-1}$ para os anos de 2012 e 2013, respectivamente de KCL e 550, 450kg.ha ${ }^{-1}$ de ss para os anos de 2012 e 2013 , respectivamente; cobertura: uréia - $120 \mathrm{~kg} \mathrm{ha}^{-1}$, dividida em duas aplicações; Cloreto de potássio -70, 40kg.ha ${ }^{-1}$, dividida em duas aplicações, para os anos de 2012, 2013, respectivamente. Estercos bovino, ovino e cama de frango: plantio= $3 \mathrm{~kg} \cdot \mathrm{m}^{-2}$ cobertura $=2 \mathrm{~kg} \cdot \mathrm{m}^{-2}$. Esterco de aves: plantio $1,5 \mathrm{~kg} \cdot \mathrm{m}^{-2}$, cobertura $=; 0,5 \mathrm{~kg} \cdot \mathrm{m}^{-2}$. Composto orgânico: plantio $=0,5 \mathrm{~kg} \cdot \mathrm{m}^{-2}$, cobertura $=0,5 \mathrm{~kg} \cdot \mathrm{m}^{-2} \cdot \mathrm{CV}=$ coeficiente de variação. 
Tabela 8. Massa fresca (MF) e Produtividade $\left(\mathrm{kg} \cdot \mathrm{m}^{-2}\right)$ de plantas de alface Lactuca sativa, cv. Vanda, submetidas à fertilização orgânica e mineral no período de verão do ano de 2015 no Distrito Federal. UnB-FAV, 2016.

\begin{tabular}{lcc}
\hline \multicolumn{1}{c}{ Tratamento } & MF & Produtividade \\
\hline Controle & $187,50 \mathrm{~b}$ & $2,083 \mathrm{~b}$ \\
Químico & $198,50 \mathrm{~b}$ & $2,205 \mathrm{~b}$ \\
Composto orgânico & $209,25 \mathrm{ab}$ & $2,324 \mathrm{ab}$ \\
Esterco bovino & $225,11 \mathrm{ab}$ & $2,500 \mathrm{ab}$ \\
Químico + esterco bovino & $252,66 \mathrm{ab}$ & $2,807 \mathrm{ab}$ \\
Químico + esterco ovino & $257,00 \mathrm{ab}$ & $2,855 \mathrm{ab}$ \\
Químico + composto & $277,50 \mathrm{ab}$ & $3,083 \mathrm{ab}$ \\
Esterco ovino & $284,00 \mathrm{ab}$ & $3,155 \mathrm{ab}$ \\
Químico + esterco de aves & $338,50 \mathrm{ab}$ & $3,760 \mathrm{ab}$ \\
Esterco de aves & $371,50 \mathrm{a}$ & $4,127 \mathrm{a}$ \\
\hline CV(\%) & 26,16 & 26,16 \\
\hline
\end{tabular}

Médias seguidas pela mesma letra nas colunas, não diferem estatisticamente entre si, pelo teste de Tukey a $5 \%$ de probabilidade. Químico= plantio: $40 \mathrm{~kg} \cdot \mathrm{ha}^{-1}$ de uréia; $40 \mathrm{~kg} \cdot \mathrm{ha}^{-1}$ de KCL e $300 \mathrm{~kg} \cdot \mathrm{ha}^{-1}$ de ss; cobertura: uréia - 120kg.ha ${ }^{-1}$, dividida em duas aplicações; Cloreto de potássio -80kg.ha ${ }^{-1}$, dividida em duas aplicações. Estercos bovino, ovino e cama de frango: plantio $=3 \mathrm{~kg} \cdot \mathrm{m}^{-2}$ cobertura $=2 \mathrm{~kg} \cdot \mathrm{m}^{-2}$. Esterco de aves: plantio $1,5 \mathrm{~kg} \cdot \mathrm{m}^{-2}$, cobertura=; $0,5 \mathrm{~kg} \cdot \mathrm{m}^{-2}$. Composto orgânico: plantio $=0,5 \mathrm{~kg} \cdot \mathrm{m}^{-2}$, cobertura $=0,5 \mathrm{~kg} \cdot \mathrm{m}^{-2}$. $\mathrm{CV}=$ coeficiente de variação.

Silva et al. (2014) analisaram a produção de alface, produzida sob diferentes doses de biofertilizante líquido feito através da digestão aeróbica de substratos orgânicos (esterco bovino fresco, leite e outros ingredientes) e não observaram diferença estatística entre os tratamentos para a produção de alface.

Oliveira et al. (2014) testaram diferentes doses de esterco avícola na produção de alface Lucy Brown e Vanda. As doses variaram de 1,5 a 3,0 kg. $\mathrm{m}^{2}$. Os autores verificaram que não houve efeito de dose na produção de massa fresca para ambos os materiais e concluíram que a utilização de $1,5 \mathrm{~kg} . \mathrm{m}^{2}$ é mais vantajosa.

Morais et al. (2014) avaliaram o efeito da aplicação de húmus líquido em cobertura e de húmus sólido, incorporado ao solo, em características agronômicas de plantas de alface. 
Os autores verificaram que a aplicação de húmus sólido incorporado ao solo propiciou aumento do sistema radicular e consequentemente aumento na produção de massa fresca.

Soares et al. (2014) estudaram o efeito da aplicação de dejeto líquido de suínos na produção de alface crespa. Os autores relataram que a utilização de $40 \mathrm{~m}^{3}$ de dejeto líquido, aplicado ao solo em diferentes épocas, não proporcionou aumento na produção de alface, provavelmente pela alta fertilidade do solo.

Com o objetivo de avaliar o uso de três tipos de esterco animal: de frango, de bovino e de ovino na produção de alface, Peixoto Filho et al. (2013) conduziram um experimento de campo com o delineamento experimental em blocos casualizados, com três estercos e cinco doses, com dois tratamentos adicionais, só fertilizante mineral e o controle (sem fertilização), com quatro repetições. Foram avaliadas as variáveis: matéria fresca e matéria seca por planta, produtividade e número de folhas por planta. $\mathrm{O}$ esterco de frango proporcionou maiores produtividades de alface no primeiro cultivo; contudo, a partir do segundo cultivo foi superado pelos estercos bovino e ovino. As maiores doses dos estercos proporcionaram boas produtividades até o terceiro cultivo sendo necessária nova aplicação dos mesmos para a manutenção de bons resultados. O fertilizante mineral promoveu boas produtividades até o segundo cultivo tornando-se conveniente nova aplicação a partir do terceiro cultivo.

Santi et al. (2013) avaliaram as características agronômicas de cultivares de alface americana mediante doses de torta de filtro (subproduto do processamento industrial da cana de açúcar), em ambiente protegido. Os autores verificaram melhorias no crescimento e qualidade comercial da alface americana.

Martins et al. (2013) trabalharam com diferentes tipos e combinações de fontes orgânicas e fosfatadas sobre a produção de massa fresca e seca de alface Verônica. Os autores verificaram que a rocha fosfatada quando conjugada aos adubos orgânicos proporcionou maior produção de massa fresca e seca.

Santos et al. (2013) avaliaram desempenho agronômico de alface crespa com aplicação de fertilizantes orgânicos e organominerais. Os autores não observaram diferenças estatísticas para a produção de massa fresca entre os diferentes tratamentos.

Batista et al. (2012), que avaliou a influência de diferentes fontes de adubação na produtividade da alface cv. Elba. Os tratamentos consistiram da combinação de quatro fontes de adubação: Humus de minhoca a partir de esterco bovino, composto orgânico, esterco bovino, adubação orgânica e mineral. Não houve diferença estatística entre os 
tratamentos. Para a característica massa fresca comercial, a adubação orgânica + mineral resultou em $260 \mathrm{~g}$.

Silva (2011) realizou um trabalho cujo objetivo foi avaliar a influência de diferentes fontes de adubação na produção de alface. Os autores usaram fertilização mineral e fertilização orgânica com húmus de minhoca e composto orgânico. Eles observaram maior produção com a fertilização mineral. Nos experimentos do atual trabalho realizados na Fazenda Água Limpa também foi observado o baixo desempenho da alface sob fertilização com composto orgânico que não diferiu do desempenho observado com a fertilização química.

Viana e Vasconcelos (2008) observaram aumento significativo na produtividade de alface crespa, variedade Vera, ao utilizar esterco bovino e cama de frango.

Trabalhos realizados por Marchi (2006) foram desenvolvidos com o objetivo de observar a influência da adubação orgânica e a prática da calagem na produção de alface americana. $\mathrm{O}$ autor observou que o esterco de aves promoveu maior desenvolvimento de raízes e maior produção de matéria seca de alface, quando comparado ao observado em parcelas com composto orgânico e fertilização mineral. O mesmo autor, em outro ensaio, observou que quando a alface recebe fertilização mineral, a prática de correção da acidez do solo com calcário é essencial para propiciar maior crescimento da cultura.

Considerando os resultados apresentados referentes aos experimentos realizados na Fazenda Água Limpa, para o presente estudo, infere-se que a adição de fertilizantes químicos aos estercos animais, utilizados nos experimentos dos anos de 2012, 2013 e 2015, não apresenta viabilidade técnica e, provavelmente, também não apresenta viabilidade econômica, visto que não foi observada diferença estatística entre os tratamentos com fertilização orgânica aplicada isoladamente e as misturas.

Com a correção adequada do solo, fornecimento de água à cultura, conforme demanda, e havendo disponibilidade de estercos animais, desde que devidamente compostados, não há necessidade de adição de fertilizantes minerais, pois estes não proporcionaram aumento de produtividade na cultura da alface cv. Vanda. 


\subsection{Contaminação de alface por cádmio, chumbo e microrganismos}

Considerando as amostras de folhas de alface cv. Vanda provenientes dos experimentos realizados no período de inverno de 2012 e verão de 2013, não foram observadas contaminação da hortaliça por Cádmio Total $(\mathrm{Cd})$ e Chumbo Total $(\mathrm{Pb})$ em plantas cultivadas sob fertilização orgânica e fertilização mineral. Não foram identificadas amostras contaminadas em nenhum dos experimentos e tratamentos.

Em Mato Grosso do Sul, Cônsolo (2015) mediu a concentração de magnésio, zinco, cobre, ferro, alumínio, cromo, níquel, cobalto e molibdênio em batata inglesa, batata doce, mandioca, inhame e taro para avaliação do seu conteúdo nutricional e índices de contaminação. $\mathrm{O}$ estudo mostrou traços dos elementos avaliados e que na proporção observada representam fontes complementares importantes aos requerimentos dos principais minerais para a dieta diária.

Oliveira et al. (2014) avaliou a composição mineral, bem como a contaminação por metais pesados, em alface crespa em solos tratados com diferentes doses e tipos de composto orgânico. O experimento foi conduzido em casa de vegetação, com cinco tipos de compostos orgânicos e quatro doses de nitrogênio. De maneira geral, as doses dos compostos estudados não foram suficientes para fornecer a quantidade necessária de nutrientes para a alface, com exceção das de nitrogênio. Não se observou elevação dos teores de metais pesados no solo, acima do permitido pela legislação brasileira. Compostos a base de esterco acrescido de capim resultaram em teores de zinco ( $\mathrm{Zn}$ ) nas plantas acima do recomendado para o consumo.

De Andrade e Moraes (2013) quantificaram os teores de $\mathrm{Cd}$, Cromo $(\mathrm{Cr})$ e $\mathrm{Pb}$ em amostras de fertilizantes orgânicos, de solos e de plantas de alface de áreas de produção olerícola localizadas nos municípios de Novo Hamburgo e São Leopoldo - RS. A maioria das amostras apresentou teor de $\mathrm{Pb}$ abaixo do limite máximo considerado seguro para o consumo humano. No entanto, foi verificado em cinco amostras de alface teor de $\mathrm{Pb}$ acima do limite, duas em áreas de cultivo convencional e três em área de cultivo orgânico.

Machado et al. (2008) avaliou o efeito de dois diferentes compostos orgânicos, cama de frango e torta de mamona, sobre a concentração de $\mathrm{Pb}$ em alface tipo crespa, da cultivar Mariane. Os tratamentos foram os compostos orgânicos cama de frango, torta de mamona e o controle com ausência de adubação. Amostras retiradas da área nos meses de agosto e setembro apresentaram maior nível de $\mathrm{Pb}$, com exceção das amostras cultivadas sem adubação. Os maiores valores foram encontrados nas amostras cultivadas com cama de 
frango, seguidas das cultivadas com torta de mamona. As concentrações médias de $\mathrm{Pb}$ na alface foram 1,38, 0,83 e 0,15 ppm peso fresco para as amostras adubadas com cama de frango, torta de mamona e sem adubação. Os níveis encontrados nas amostras cultivadas com cama de frango e torta de mamona foram superiores ao limite máximo permitido preconizado pelo Codex Alimentarius.

Mattiazzo et al. (2002) avaliaram os efeitos da aplicação sucessiva de composto de lixo urbano sobre os teores de $\mathrm{Cd}, \mathrm{Cr}, \mathrm{Cu}, \mathrm{Ni}, \mathrm{Pb}$ e $\mathrm{Zn}$ em plantas de cana-de-açúcar, sendo o composto aplicado nas doses de $0 ; 20 ; 40$ e 60 t.ha $^{-1}$. A aplicação consecutiva do composto por duas safras agrícolas aumentaram o teor de $\mathrm{Cu}$ no solo que variou, em relação à testemunha, de 12 a $25 \%$, no primeiro ano agrícola, e de 27 a $88 \%$, no segundo ano agrícola. Para Zn, esses valores variaram de 12 a $72 \%$ e de 72 a $156 \%$, no primeiro e no segundo ano, respectivamente, e de $\mathrm{Cr}$ de 12 a $25 \%$, no segundo ano. Os teores totais de $\mathrm{Cd}$, $\mathrm{Ni}$ e $\mathrm{Pb}$, no solo, e de $\mathrm{Cd}$, $\mathrm{Cr}$, $\mathrm{Ni}$ e $\mathrm{Pb}$, nas folhas, colmos e caldo das plantas, mantiveram-se abaixo do limite de determinação.

Em trabalho realizado por Costa et al. (2001) avaliou-se o emprego do composto de lixo urbano em três cultivos sucessivos da alface. Os tratamentos consistiram de quatro doses de composto de lixo $\left(0,10,20\right.$ e 30 t.ha $\left.^{-1}\right)$ e três cultivares de alface (Regina, Vitória Verde Clara e Brasil - 303). Determinou-se o teor de $\mathrm{Cu}, \mathrm{Pb}, \mathrm{Cd}$ e $\mathrm{Zn}$ na matéria seca do tecido vegetal, após a colheita no primeiro, segundo e terceiro cultivos, correspondente a 46, 142 e 222 dias da aplicação do composto, respectivamente. O teor de metais pesados na planta foi incrementado, principalmente, no primeiro cultivo, seguindo a seguinte ordem decrescente: $\mathrm{Pb}>\mathrm{Cd}>\mathrm{Cu}>\mathrm{Zn}$. No segundo cultivo, o efeito foi menor e no terceiro cultivo não houve efeito do composto, o que foi atribuído ao esgotamento do seu efeito. Nenhum dos elementos atingiu níveis considerados fitotóxicos.

Nos experimentos realizados na Fazenda Água Limpa, para o presente estudo, no inverno de 2012 e verão de 2013, não foi observada contaminação da alface por $\mathrm{Cd}$ e $\mathrm{Pb}$. As possíveis causas para o resultado são a ausência dos elementos nos fertilizantes orgânicos e minerais utilizados, ausência de $\mathrm{Cd}$ e $\mathrm{Pb}$ no solo e na água de irrigação. Esse resultado também reflete o correto manejo do solo em plantios anteriores.

Quanto à contaminação das folhas de alface cv. Vanda por Coliformes Termotolerantes (Tabela 9) e Salmonella spp. (Tabela 10), verificou-se a ausência dos microrganismos em todos os tratamentos do experimento realizado no ano de 2015. Dessa forma, o produto está de acordo com os padrões legais vigentes para as situações 
enquadradas no item 1.1 do Anexo II do Regulamento Técnico sobre padrões microbiológicos para alimentos (Anexo 2).

Bartz (2015) avaliou a contaminação microbiológica e a segurança de alfaces convencionais produzida na região Sul do Brasil, desde a produção primária até o varejo. Analisou 128 amostras de adubo orgânico, solo, água de irrigação e lavagem, mãos de manipuladores, equipamentos, mudas e pés de alface coletadas em 6 propriedades rurais, três orgânicas e três convencionais. Além disso, o autor aplicou questionário de autoavaliação, com o objetivo de obter informações sobre os sistemas de gestão implementados nas propriedades rurais. Os resultados obtidos na produção primária demonstraram baixas contagens de E. coli e ausência de patógenos em todas as amostras coletadas, porém um alto risco microbiológico foi identificado, para todas propriedades, através do questionário de auto-avaliação. Os resultados também demonstraram que as propriedades orgânicas apresentaram risco microbiológico maior e presença de patógenos quando comparadas com as propriedades convencionais, fato explicado pela utilização de adubo orgânico produzido na própria propriedade, sem adequada compostagem. As alfaces coletadas nos hipermercados demonstraram $4 \%$ de prevalência de E. coli e presença de Salmonella em uma amostra. Salmonella e E. coli não se multiplicaram na alface a 5 e $10^{\circ} \mathrm{C}$ durante 48 horas, sugerindo serem estas temperaturas adequadas para o armazenamento. Por outro lado, os mesmos microrganismos se multiplicaram a 25 e $37^{\circ} \mathrm{C}$, atingindo níveis elevados que podem oferecer risco à saúde do consumidor, mesmo após uma higienização adequada. 
Tabela 9. Presença de Coliformes Termotolerantes na fase presuntiva e confirmativa em folhas de alface (Lactuca sativa) cv. Vanda submetidas à fertilização orgânica e mineral no período de verão do ano de 2015 no Distrito Federal. UnB-FAV, 2016.

\begin{tabular}{|c|c|c|c|c|c|c|}
\hline \multirow[b]{2}{*}{ Tratamento } & \multirow{2}{*}{$\begin{array}{c}\text { Fase } \\
\text { Presuntiva } \\
\text { Combinação de } \\
\text { tubos }+\end{array}$} & \multirow{2}{*}{$\begin{array}{c}\text { Fase } \\
\text { Confirmativa } \\
\text { Combinação de } \\
\text { tubos }+\end{array}$} & \multirow[b]{2}{*}{$\mathrm{NMP} / \mathrm{g}$} & \multicolumn{2}{|c|}{$\begin{array}{c}\text { Intervalo de } \\
\text { confiança }(95 \%)\end{array}$} & \multirow[b]{2}{*}{ Condição } \\
\hline & & & & Mínimo & Máximo & \\
\hline Branco & $3-3-2$ & $2-0-0$ & 9 & 1 & 36 & Adequado* \\
\hline Esterco bovino & $3-2-2$ & $2-0-0$ & 9 & 1 & 36 & Adequado* \\
\hline Composto & $3-3-3$ & $0-0-0$ & $<3$ & $<0,5$ & $<9$ & Adequado* \\
\hline Químico +composto & $3-2-1$ & $0-0-0$ & $<3$ & $<0,5$ & $<9$ & Adequado* \\
\hline Esterco de aves & $3-3-0$ & $0-0-0$ & $<3$ & $<0,5$ & $<9$ & Adequado* \\
\hline Químico & $3-2-0$ & $0-0-0$ & $<3$ & $<0,5$ & $<9$ & Adequado* \\
\hline Esterco ovino & $3-3-2$ & $0-0-0$ & $<3$ & $<0,5$ & $<9$ & Adequado* \\
\hline Químico+aves & $3-0-2$ & $0-0-0$ & $<3$ & $<0,5$ & $<9$ & Adequado* \\
\hline Químico+ovino & $3-3-1$ & $0-0-0$ & $<3$ & $<0,5$ & $<9$ & Adequado* \\
\hline Químico+bovino & $3-3-3$ & $0-0-0$ & $<3$ & $<0,5$ & $<9$ & Adequado* \\
\hline
\end{tabular}

* produto ou lote está de acordo com os padrões legais vigentes para as situações enquadradas no item 1.1 do Anexo II do Regulamento Técnico sobre padrões microbiológicos para alimentos (ANVISA, 2001). 
Tabela 10. Presença de Salmonella spp. em folhas de alface (Lactuca sativa) cv. Vanda submetidas à fertilização orgânica e mineral no período de verão do ano de 2015 no Distrito Federal. UnB-FAV, 2016.

\begin{tabular}{ccc}
\hline Amostra & RVS / TT & BPLS \\
\hline Branco & Ausente & $-*$ \\
Esterco bovino & Ausente & $-*$ \\
Composto & Ausente & $-*$ \\
Químico +composto & Ausente & $-*$ \\
Esterco de aves & Presente & Ausente* \\
Químico & Ausente & $-*$ \\
Esterco ovino & Ausente & $-*$ \\
Químico+aves & Ausente & $-*$ \\
Químico+ovino & Ausente & $-*$ \\
Químico+bovino & Ausente & $-*$ \\
\hline
\end{tabular}

* produto ou lote está de acordo com os padrões legais vigentes para as situações enquadradas no item 1.1 do Anexo II do Regulamento Técnico sobre padrões microbiológicos para alimentos (ANVISA, 2001).

Engel e Tondo (2014) avaliaram a contaminação microbiológica de alfaces provenientes de sistemas de cultivos convencionais em diferentes fases de seu cultivo, em produtores do Estado do Rio Grande do Sul (RS). Um total de 128 amostras de água de irrigação, solo, solo adubado, adubos, alfaces, superfícies de caixas para transporte do produto, superfície das mãos dos trabalhadores foi coletado em três fazendas produtoras de alface convencional, no RS. As maiores contagens de E. coli foram observadas no período de duas e uma semana antes da colheita do produto. Contudo, na colheita, as contagens de E. coli nas amostras de solo, adubo, solo adubado e alfaces demonstraram estar abaixo do limite de detecção do método utilizado. As contagens de coliformes totais permaneceram praticamente inalteradas, sugerindo que estes microrganismos não foram bons indicadores para avaliação da contaminação microbiológica no cultivo do alface. Dentre as amostras de água, 88,5\% apresentaram contagens de E. coli abaixo do limite de detecção, demonstrando que a água utilizada para irrigação e lavagem estavam, na sua maioria, adequadas. Em relação às amostras da superfície das caixas utilizadas para transporte do produto e mãos de trabalhadores, todas apresentaram contagens médias de E. coli menores que 1,00 $\log 10$ $\mathrm{UFC} / \mathrm{cm}^{2}$. Nenhuma amostra tinha a presença de Salmonella spp. ou E. coli O157:H7.

Muller (2014) fez um estudo com o objetivo de investigar a implementação de BPA e a contaminação microbiana na produção de alfaces orgânicas, em três propriedades do Estado do Rio Grande do Sul. Entrevistas foram realizadas com os responsáveis pelas propriedades, 
utilizando um questionário de auto-avaliação, o qual avaliou o contexto da produção, assim como as características dos sistemas de gestão da segurança de alimentos implementados ou não nas propriedades. Paralelamente a isso, em cada fazenda foram coletadas amostras ( $\mathrm{n}=$ 132) de adubo, solo, solo adubado, água de lavagem, água de irrigação, da superfície de mãos dos trabalhadores, superfícies de equipamentos, mudas de alface e alfaces prontas para serem distribuídas no mercado. Os resultados demonstraram que todas as propriedades estavam operando com um risco de moderado a alto em relação à possibilidade de contaminação microbiológica. Corroborando com esses resultados, E. coli foi isolada em números superiores a 10UFC/g nas amostras de adubo, solo adubado e alface durante o cultivo, e em quantidades superiores a 1UFC/100mL nas amostras de água de irrigação e água de lavagem. E. coli O157:H7 foi detectada em uma amostra de água de irrigação e em uma amostra de água de lavagem. Salmonella spp. foi detectada em uma amostra de adubo orgânico e em uma amostra de alface, coletada duas semanas antes de ser colhida. No entanto, nenhuma das 36 amostras de alface prontas para ir ao mercado apresentou E. coli O157:H7 ou Salmonella spp. e poucas amostras apresentaram E. coli. Também não foram detectados microrganismos patogênicos nas superfícies das mãos dos trabalhadores e dos equipamentos.

Em estudo realizado por Costa et al. (2012), avaliou-se alfaces provenientes de cultivos convencional e orgânico, e determinou a contaminação de coliformes a $45^{\circ} \mathrm{C}$ e Salmonella spp. As amostras de alface provenientes de cultivos convencionais apresentaram maior incidência de contaminação por coliformes a $45^{\circ} \mathrm{C}$ do que as provenientes de sistemas orgânicos de cultivo.

Barros et al. (2013) verificaram a qualidade microbiológica de alfaces comercializadas em supermercados da cidade de Juazeiro do Norte - Ceará. Foram realizadas análises de coliformes totais e termotolerantes e Salmonella spp. Os resultados obtidos para coliformes totais e fecais mostraram que as amostras estavam fora dos padrões estabelecidos pela legislação. Para Salmonella spp, o trabalho revelou que todas as amostras (100\%) encontravam-se de acordo com o padrão federal vigente.

Estudo realizado por Rodrigues (2013) teve como objetivo avaliar a cadeia produtiva de alfaces orgânicas no sul do Brasil, através de análises microbiológicas e dos sistemas de gestão da inocuidade, buscando identificar possíveis medidas de intervenção a partir do ponto de vista da segurança dos alimentos. Três propriedades rurais de alface orgânica foram analisadas, utilizando as ferramentas Horticultura Assessment Scheme (HAS) e Horticulture Safety Management System Diagnosis (HSMS-DI). Amostras de adubo, solo adubado, mudas de alface, alface, água de irrigação e lavagem foram coletadas ao longo da cadeia produtiva, 
seguindo a ordem de inicio do plantio, durante o crescimento e na colheita das alfaces. As análises microbiológicas foram realizadas segundo o protocolo do HAS e normas internacionais. Para avaliação dos sistemas de gestão de segurança dos alimentos a ferramenta de diagnóstico HSMS-DI, com 58 questões, foi aplicada em cada propriedade rural. As Informações obtidas no HAS e HSMS-DI foram combinadas e um diagnóstico de cada propriedade foi elaborado, assim como foram sugeridas medidas de intervenção. Os resultados do HSMS-DI indicaram que as propriedades rurais apresentavam clara organização e forte embasamento quanto à prevenção dos riscos químicos. No entanto estavam operando em um contexto de risco microbiológico moderado a elevado. Os resultados obtidos com o HAS demonstraram contaminação por microrganismos de origem fecal em diversas amostras, além disso, foi detectada a presença de E. coli O157:H7 na água de irrigação, na água de lavagem das alfaces e a presença de Salmonella em adubo.

Santos e Junqueira (2012), avaliaram a contaminação microbiológica por Salmonella sp. e coliformes a $45^{\circ} \mathrm{C}$ em todos os elos da cadeia produtiva de couve minimamente processada para identificação do ponto crítico de contaminação, além da contagem de bactérias mesofílicas nas mãos dos trabalhadores para determinar a eficiência dos métodos de higiene pessoal utilizados por eles na Agroindústria Machadinho, Brazlândia-DF. Foram coletadas amostras de couve em todas as etapas do processo produtivo, dentro da agroindústria, além de amostras coletadas em supermercados de Brasília-DF. Foi detectada contaminação por coliformes a $45^{\circ} \mathrm{C}$ apenas nas amostras adquiridas nos supermercados. Verificou-se a necessidade de uma maior integração entre Agroindústria e supermercados, bem como a necessidade de treinamento de gerentes e manipuladores e a aquisição de equipamentos, objetivando a manutenção da qualidade ao longo da cadeia produtiva, com enfoque para as condições de armazenamento nos supermercados.

Arbos et al. (2010) avaliaram a qualidade sanitária de hortaliças orgânicas no que se refere à contaminação microbiológica por coliformes totais e fecais, presença de Salmonella $s p$. e contaminação parasitológica em alface, tomate e cenoura cultivados organicamente, provenientes da Região Metropolitana de Curitiba-PR. Coliformes fecais foram detectados em $40 \%$ das amostras de alface e em $25 \%$ das amostras de cenoura. A presença de Salmonella sp. foi verificada em $25 \%$ das amostras de cenoura e em $20 \%$ das amostras de alface.

Um dos objetivos do trabalho de Abreu et al. (2010) foi avaliar a contaminação de alface por Salmonella sp. e coliformes a $45^{\circ} \mathrm{C}$, cultivada sob adubação orgânica. Os tratamentos foram: Testemunha (sem adubação); Adubação química; Esterco de galinha; Esterco bovino; Húmus de minhoca e Composto orgânico. Não foi observada contaminação do solo e adubos 
orgânicos por esses microorganismos. Porém, foi observada contaminação da água de irrigação e da alface por coliformes fecais. Os autores alegaram existir fortes indícios de que a água de irrigação tenha sido o principal veículo de contaminação.

Alves et al. (2007) avaliaram 108 amostras de alface orgânica e convencional provenientes de unidades de produção, feiras livres e supermercados para contaminação de coliformes termotolerantes. Os autores não observaram contaminação nas amostras avaliadas.

Silva (2005) avaliou a qualidade microbiológica de alface orgânica certificada e produzida no Distrito Federal e constatou que 97\% das 72 amostras retiradas junto à propriedades rurais apresentavam contaminação por coliformes fecais acima do permitido pela legislação. Não foi observada a presença de Salmonella nas amostras analisadas.

Os resultados observados na literatura evidenciam a necessidade de implementação de Boas Práticas Agrícolas, onde a compostagem adequada e qualidade microbiológica da água de irrigação e lavagem sejam priorizadas para evitar a contaminação de alfaces na produção primária. Fica também evidente que após a colheita, os vegetais folhosos frescos devem ser mantidos em cadeia refrigerada, abaixo de $10^{\circ} \mathrm{C}$, até o consumo, a fim de evitar riscos de surtos alimentares relacionados a estes produtos.

Os adubos orgânicos têm sido citados como os responsáveis pela contaminações de hortaliças no Brasil. No presente trabalho, realizado na Fazenda Água Limpa, não foi constatada contaminação da alface colhida no ano de 2015 por Coliformes termotolerantes e Salmonella spp. Infere-se, portanto, que os fertilizantes testados, sejam eles de origem mineral ou orgânica, não ofereceram riscos de contaminação microbiológica à alface e que o manejo e tratos culturais realizados durante o plantio e colheita foram adequados.

\subsection{Teor de clorofilas $a$ e $b$, clorofila total $(a+b)$ e carotenóides totais em plantas de alface}

Os valores médios de absorbância de clorofila $a$ e $b$, clorofila total $(a+b)$, carotenóides totais e valores calculados para as concentrações de clorofila $a$ e $b$, clorofila total $(a+b)$ e carotenóides totais estão apresentados na Tabela 11. Não houve diferença estatística entre os tratamentos para os teores observados nas plantas de alface.

Bizzo (2015) avaliou se a melhoria fotossintética, maior assimilação de $\mathrm{CO}_{2}$ em Eichhornia crassipes (Mart.) Solms, quando exposta a $1 \mathrm{mM} \mathrm{de} \mathrm{Cr}^{+3}$, estava relacionada à alterações ecofisiológicas (fotoquímicas e de pigmentos), anatômicas e/ou ultraestruturais. Parâmetros da fluorescência da clorofila a, conteúdo de pigmentos fotossintéticos, alterações 
anatômicas nas raízes e alterações ultraestruturais nas folhas foram avaliados. $\mathrm{O}$ autor não observou variações no conteúdo de pigmentos fotossintéticos.

Alves (2015) analisou os efeitos da deficiência hídrica sobre o potencial hídrico, as taxas de trocas gasosas, parâmetros de fluorescência da clorofila e o conteúdo de pigmentos cloroplastídicos em tomate selvagem e mutantes. As plantas foram cultivadas em casa de vegetação sob condições controladas de temperatura e umidade. As análises foram realizadas em plantas de 35 dias de idade cuja irrigação foi suspensa por 5 dias e reidratadas no sexto dia. O grupo controle permaneceu sob disponibilidade hídrica normal. O mutante hp1 apresentou maior concentração de clorofila a, clorofila b e carotenóides. Os dados permitiram concluir que os mutantes apresentam maior tolerância à deficiência hídrica em relação a cultivar selvagem. 
Tabela 11. Valores médios de absorbância e teores de clorofila $a$ e $b\left(u \mathrm{~g} \cdot \mathrm{g}^{-1}\right.$ de massa fresca), clorofila total $(a+b)$ e carotenóides totais em folhas de alface (Lactuca sativa), cv. Vanda,submetidas à fertilização orgânica e mineral no período de inverno, do ano de 2012, no Distrito Federal. UnB-FAV, 2016.

\begin{tabular}{|c|c|c|c|c|c|c|c|c|c|c|c|c|}
\hline Fertilização & $\begin{array}{l}\text { Área } \\
\left(\mathbf{c m}^{2}\right)\end{array}$ & $\begin{array}{c}\text { volume } \\
(\mathrm{mL})\end{array}$ & A663.8 & A646.8 & A480 & Chlor A* & $\begin{array}{c}\text { Chlor } \\
\text { B** }\end{array}$ & Car.*** & $\begin{array}{c}\text { Chlor A } \\
u_{\text {g.g }}{ }^{-1}\end{array}$ & $\begin{array}{c}\text { Chlor B } \\
\text { ug.g }\end{array}$ & $\begin{array}{c}\text { Car. } \\
\text { ug. } \mathrm{g}^{-1}\end{array}$ & $\begin{array}{c}\text { ChlA+B } \\
u g . g^{-1}\end{array}$ \\
\hline Composto & 0,1 & 1 & 0,338 & 0,183 & 0,302 & 3,495 & 2,157 & 1,836 & $34,952 \mathrm{a}$ & $21,577 \mathrm{a}$ & $18,365 \mathrm{a}$ & $56,529 a$ \\
\hline Químico+ovino & 0,1 & 1 & 0,498 & 0,268 & 0,454 & 5,149 & 3,151 & 2,782 & $51,496 a$ & $31,515 \mathrm{a}$ & $27,825 a$ & $83,011 \mathrm{a}$ \\
\hline Químico+aves & 0,1 & 1 & 0,460 & 0,260 & 0,411 & 4,713 & 3,157 & 2,435 & $47,138 \mathrm{a}$ & $31,570 \mathrm{a}$ & $24,355 \mathrm{a}$ & $78,708 \mathrm{a}$ \\
\hline Químico+cama de frango & 0,1 & 1 & 0,445 & 0,247 & 0,391 & 4,579 & 2,958 & 2,333 & $45,790 \mathrm{a}$ & $29,581 \mathrm{a}$ & $23,337 \mathrm{a}$ & $75,371 \mathrm{a}$ \\
\hline Químico & 0,1 & 1 & 0,524 & 0,296 & 0,453 & 5,367 & 3,593 & 2,654 & $53,674 \mathrm{a}$ & $35,937 \mathrm{a}$ & $26,542 \mathrm{a}$ & $89,612 a$ \\
\hline Bovino & 0,1 & 1 & 0,476 & 0,257 & 0,406 & 4,920 & 3,026 & 2,430 & $49,204 \mathrm{a}$ & $30,261 \mathrm{a}$ & $24,309 a$ & $79,466 \mathrm{a}$ \\
\hline Químico+bovino & 0,1 & 1 & 0,494 & 0,284 & 0,432 & 5,045 & 3,502 & 2,512 & $50,452 \mathrm{a}$ & $35,022 \mathrm{a}$ & $25,128 \mathrm{a}$ & $85,475 a$ \\
\hline Aves & 0,1 & 1 & 0,496 & 0,272 & 0,422 & 5,108 & 3,246 & 2,500 & $51,083 a$ & $32,463 a$ & $25,002 \mathrm{a}$ & $83,547 a$ \\
\hline Ovino & 0,1 & 1 & 0,580 & 0,300 & 0,500 & 6,032 & 3,413 & 3,077 & $60,323 a$ & $34,131 \mathrm{a}$ & $30,772 \mathrm{a}$ & $94,454 \mathrm{a}$ \\
\hline Cama de frango & 0,1 & 1 & 0,575 & 0,287 & 0,480 & 6,007 & 3,173 & 2,984 & $60,073 a$ & $31,735 \mathrm{a}$ & $29,840 \mathrm{a}$ & $91,808 \mathrm{a}$ \\
\hline CV\% & & & & & & & & & 24.28 & 26.03 & 22.73 & 24.57 \\
\hline
\end{tabular}

Médias seguidas pela mesma letra nas colunas, não diferem estatisticamente entre si, pelo teste de Tukey a $5 \%$ de probabilidade. Químico= plantio: 40kg.ha ${ }^{-1}$ de uréia; $35 \mathrm{~kg} . \mathrm{ha}^{-1}$ de KCL e 550kg.ha ${ }^{-1}$ de ss; cobertura: uréia - $120 \mathrm{~kg}$ ha $^{-1}$, dividida em duas aplicações; Cloreto de potássio $-70 \mathrm{~kg}$. ha ${ }^{-1}$, dividida em duas aplicações. Estercos bovino, ovino e cama de frango: plantio $=3 \mathrm{~kg} \cdot \mathrm{m}^{-2}$ cobertura $=2 \mathrm{~kg} \cdot \mathrm{m}^{-2}$. Esterco de aves: plantio $1,5 \mathrm{~kg} \cdot \mathrm{m}^{-2}$, cobertura $=; 0,5 \mathrm{~kg} \cdot \mathrm{m}^{-2}$. Composto orgânico: plantio $=0,5 \mathrm{~kg} \cdot \mathrm{m}^{-2}$, cobertura $=$ $0,5 \mathrm{~kg} \cdot \mathrm{m}^{-2} \cdot \mathrm{CV}=$ coeficiente de variação.

$*=(12$ XA663.8 - 3,11 XA646.8) X volume

$* *=(20,78$ XA646.8 - 4,88 XA663.8) X volume

$* * *==(1000 \mathrm{XA} 480-1,12 \mathrm{XChlor} \mathrm{A*}-34,07 \mathrm{XChlor} \mathrm{B**}) / 245) \mathrm{X} 2$ 
Muito embora não tenha ocorrido diferença entre os tratamentos para o teor de clorofila $a$, verificou-se que o esterco ovino e a cama de frango apresentaram resultados superiores, o que pode explicar o fato das maiores produções de matéria fresca e produtividade terem sido observadas nestes mesmos tratamentos.

Para clorofila $b$, a fertilização química se destacou enquanto o composto novamente apresentou o menor valor. O esterco ovino e a cama de frango proporcionaram plantas de alface com teores elevados de clorofila $b$ o que confirma a importância deste pigmento para aumento da taxa fotossintética e consequentemente aumento da produtividade. $\mathrm{O}$ somatório dos pigmentos de clorofila $a$ e $b$ apresentaram comportamento similar aos observado pelos pigmentos expressos de forma isolada.

Os carotenóides totais foram mais elevados nas plantas sob fertilização com esterco de ovinos e cama de frango, enquanto apresentou resultado inferior nas plantas fertilizadas com o composto orgânico.

Segundo Taiz e Zeiger (2004), o teor de clorofilas nas folhas é influenciado por diversos fatores bióticos e abióticos, estando diretamente relacionado com o potencial de atividade fotossintética das plantas. Portanto, presença maior de clorofila resulta em maior atividade fotossintética e maior produção de massa verde, fato observado nos tratamentos com esterco ovino e cama de frango no experimento do presente estudo realizado na Fazenda Água Limpa.

Considerando a composição dos fertilizantes orgânicos utilizados no experimento e apresentados na tabela 3, verificou-se que Nitrogênio e Fósforo estão em quantidades superiores nos estercos animais comparados ao teores presentes no composto orgânico. $\mathrm{O}$ teor de Nitrogênio variou de três a seis vezes a mais nos estercos animais, a exemplo do teor de presente na cama de frango, que foi seis vezes superior ao observado no composto orgânico. Com o Fósforo também se observa comportamento similar, com variação de quatro vezes a mais nos estercos animais comparado ao composto orgânico.

Tanto Nitrogênio quanto Fósforo fazem parte do processo de fotossíntese e produção de assimilados pelas plantas. Baixos teores de Nitrogênio reduzem a síntese de pigmentos fotossintéticos. Cerca de $90 \%$ da produção de matéria seca da planta de alface resultam do processo de fotossíntese, segundo Pereira e Machado (1987). Presença mais acentuada destes elementos contribuiu para o incremento da produção de massa fresca nas parcelas que receberam fertilização orgânica à base de esterco. É possível observar também que com exceção de Potássio, todos os demais elementos da composição destes insumos estão 
em valores superiores nos estercos quando são comparados ao observado no composto orgânico. Segundo Lawlos e Cornic (2002) e Silva et . al. (2010), o Fósforo é responsável por fornecer energia à planta na forma de ATP e NADPH. Fornecimento de Fósforo via solo aumenta a concentração nas folhas e a assimilação de $\mathrm{CO}_{2}$ resultando em incremento da atividade fotossintética, aumento do teor de carboidrato foliar e do teor de clorofila, proporcionando incremento na matéria seca. Ausência de Fósforo ou fornecimento deficitário provoca distúrbios metabólicos na planta com consequente redução do crescimento. Nos experimentos atuais, realizados na fazenda Água Limpa, possivelmente devido ao reduzido teor de Fósforo observado no composto orgânico (Tabela 3), houve redução na produção de massa fresca (Tabelas 7 e 8).

Baixas concentrações de $\mathrm{Mg}$ nos fertilizantes implicam em baixa assimilação do elemento pelas plantas culminando na redução da síntese de clorofila e da taxa fotossintética (DING et. al, 2006). Na tabela 2, verifica-se que além dos teores reduzidos de Nitrogênio e Fósforo, o composto orgânico apresenta Magnésio em quantidades inferiores à dos estercos animais, o que também contribuiu para o baixo rendimento da alface produzida com composto.

Amaro (2014) avaliou o efeito da aplicação foliar da mistura de auxina (Ax), citocinina (CK) e giberelina (GA), isolada ou combinada com a mistura de nutrientes, cobalto (Co) e molibdênio (Mo), em videira 'Crimson Seedless'. O autor buscou analisar os efeitos na duração da atividade fotossintética das folhas e no metabolismo e desenvolvimento da planta, bem como no aumento da produção e qualidade de frutos. Os tratamentos foram: Testemunha; $\mathrm{CK}+\mathrm{Ax}+\mathrm{GA}$ 1,8L ha-1; $\mathrm{CK}+\mathrm{Ax}+\mathrm{GA}$ 1,8L ha-1 + Co+Mo 1,0L ha-1 e CK+Ax+GA 1,8L ha-1 + Co+Mo 1,5L ha-1. As aplicações foram realizadas em três fases: primórdio de inflorescência, bagas chumbinho e alongamento de bagas. Avaliou-se a duração da atividade fotossintética das folhas, através de avaliações nas trocas gasosas em folhas marcadas logo após a brotação, até o final do ciclo. O autor concluiu que a mistura dos reguladores vegetais, isolada ou combinada com nutrientes, favoreceu a atividade fotossintética, translocação e acúmulo de reservas, concentração de pigmentos e atividade das enzimas antioxidantes.

Santos et al. (2013) avaliaram os teores de clorofilas $a, b$ e total em alface crespa com aplicação de fertilizantes orgânicos e organominerais oriundos de um processo natural de fermentação enzimática de pescados marinhos. Os tratamentos empregados foram aplicação de fertilizante orgânico no tratamento de sementes, no tratamento de solo, três 
tratamentos foliares (um enriquecido com quitosana proveniente das carapaças de crustáceos, um enriquecido com potássio e outro sem enriquecimento - somente à base de aminoácidos) e uma testemunha (sem adição de fertilizante orgânico). Os resultados não diferiram em nenhum dos tratamentos, com exceção da variável clorofila $b$ que apresentou maiores valores no tratamento foliar enriquecido com potássio.

No atual experimento, realizado na Fazenda Água Limpa, foi observado maior teor de clorofila $b$ nas alfaces que receberam fertilização química, possivelmente devido à pronta disponibilização do nutriente potássio para a planta pelo adubo químico empregado comparada à liberação mais lenta do elemento pelos estercos (Tabela 3).

Da Silva (2013) avaliou os teores de fenóis totais, flavonóides totais, ácido ascórbico, clorofila total, nitrato, poliaminas e atividade antioxidante, presença de pesticida e microorganismos em repolho orgânico e convencional. As análises foram realizadas nos períodos de 0,12 e 20 dias de armazenamento em câmara fria e aos 12 dias em câmara fria + 4 dias de ambiente e 20 dias em câmara fria + 4 dias de ambiente (simulação de comercialização). Após a classificação os repolhos foram selecionados, higienizados e submetidos às análises nutricionais de carboidratos, proteínas, carotenóides, fibras e lipídios. Os repolhos cultivados de modo convencional apresentaram maiores teores de carboidrato e proteína. Os teores de carotenóides e lipídeos foram mais elevados logo após a sanitização e os teores de fibra foram mais elevados após 20 dias de armazenamento, ambos quando as plantas foram cultivadas em sistema orgânico.

Cassetari (2012) encontrou variabilidade genética para as características de cor das folhas e teores de clorofila e betacaroteno em cultivares de alface. $\mathrm{O}$ estudo indicou que a cultivar de alface americana é um repositório genético e apresenta potencial para auxiliar na obtenção de novas cultivares de alface com teores mais elevados de clorofila e betacaroteno.

Guassi (2012), com a finalidade de avaliar os parâmetros pós-colheita e a viabilidade do uso das cultivares de alface Piraroxa e Vanda como fontes de antioxidantes, realizou um estudo que teve como objetivo investigar suas respostas fisiológicas e bioquímicas, comparando-as entre si em diferentes temperaturas de armazenamento e em épocas de colheita distintas. As hortaliças foram armazenadas por 28 dias à $0^{\circ} \mathrm{C}$ e $95-97 \%$ UR e por quatro dias em condição ambiente monitorada. As cultivares apresentaram respostas similares, tanto para a perda de massa fresca quanto para o conteúdo de clorofila e 
carotenóides. O armazenamento refrigerado e as altas umidades relativas mostraram-se eficazes para o controle da perda de massa fresca.

Cavalcante et al. (2011) avaliaram os efeitos de diferentes condutividades elétricas da água de irrigação (CEai), associadas às épocas de aplicação de biofertilizante, sobre os teores de pigmentos fotossintéticos para a determinação dos pigmentos cloroplastídicos (clorofila $a, b$, total e carotenóides) do maracujazeiro-amarelo. Os autores verificaram que o aumento da concentração salina da água de irrigação reduziu a eficiência fotossintética nas folhas do maracujazeiro-amarelo, sendo mais drástico na condutividade superior a 2,5 $\mathrm{dS} . \mathrm{m}^{-1}$. A frequência de aplicação do biofertilizante não influenciou nas concentrações dos pigmentos fotossintéticos.

Costa (2009) avaliou os teores de clorofila nas folhas, o desempenho produtivo e a qualidade dos frutos de duas cultivares de morangueiro, Camarosa e Oso grande, conduzidas sob diferentes telas de sombreamento, em ambiente protegido. As telas de sombreamento foram colocadas sobre as plantas em forma de túnel baixo no interior do ambiente protegido. Camarosa apresentou maiores concentrações de clorofila $a ; b$ e total, independente da cor da tela de sombreamento. Houve maior produção de clorofila $b$ do que $a$, em ambas as cultivares seja na presença ou ausência de telas. Ambas as cultivares apresentaram incremento na produção de clorofila a partir de outubro, sendo crescente até o final de dezembro. No presente trabalho, realizado na Fazenda Água Limpa, verificou-se aumento da precipitação, radiação solar e temperatura ao longo dos meses de cultivo, agosto a outubro. Como os tratamentos estavam sob a mesma condição de clima, a composição dos fertilizantes utilizados possivelmente tiveram efeito direto sobre os teores de clorofila e carotenóides observados. Os estercos proporcionaram as condições mais adequadas para maior acúmulo dos pigmentos clorofila $a$, clorofila total e carotenóides e maior produção de massa fresca.

No trabalho realizado por Carvalho et al. (2007) foram medidas as concentrações de pigmentos (clorofilas $a, b$, carotenóides e antocianinas), em folhas de seis espécies de cerrado (sendo três decíduas e três sempre-verdes) em dois sítios de cerrado stricto sensu com diferenças de cobertura arbustiva-arbórea e em diferentes períodos: início do período seco (junho), fim da seca (setembro) e início das chuvas (novembro). Os maiores valores de concentração de clorofilas $a$ e $b$ foram encontrados no início (junho) em relação ao final da seca (setembro) nas duas áreas. Em junho, as concentrações de clorofilas $a$ e $b$ foram maiores na área mais densa enquanto a razão clorofila $a / b$ foi menor. 
A razão clorofila total/carotenóides também foi significativamente maior no cerrado fechado em relação ao aberto nesse período devido às maiores concentrações de clorofilas no primeiro sítio.

No presente trabalho, verificou-se que independente das condições climáticas observadas (Tabela 4), os estercos proporcionaram maior acúmulo de pigmentos fotossintéticos que refletiram na maior produção de massa fresca e seca em plantas de alface.

\subsection{Descrição do perfil metabólico e substâncias identificadas em folhas de alface}

A identificação dos constituintes da amostra por meio da comparação de índices de espectros de massas (GC-MS) culminou na identificação de 23 substâncias em cada amostra de alface referente aos tratamentos individualizados em 2012 e 2013 . Foi realizado Teste $\mathrm{F}$ entre as duas épocas de plantio para verificar a ocorrência de diferenças na concentração das substâncias em plantas de alface (Tabela 13). Das 23 substâncias, dezessete apresentaram variação de concentração entre as épocas seca (2012) e chuvosa (2013) (Anexos 3 e 4). Dessa forma, procedeu-se a análise em cada época (Tabela 12).

As concentrações das 23 substâncias foram analisadas pelo teste de Tukey em cada uma das épocas e aquelas que não apresentaram diferença estatística estão apresentadas nos anexos 3 e 4 .

O período de agosto a outubro de 2012 foi caracterizado como época de seca na região (Tabela 14). A presença de piroglutamato foi maior em plantas com a mistura de fertilização mineral e cama de frango do que em plantas adubadas apenas com o adubo mineral, com concentrações médias apresentando diferenças estatísticas entre si. Porém, não apresentaram diferenças estatísticas das médias dos demais tratamentos. O incremento de piroglutamato no tratamento com cama de frango e fertilizante mineral foi cinco vezes superior ao observado nas plantas com fertilizante mineral apenas. Em 2013, as plantas foram cultivadas em um período de maior precipitação pluviométrica comparado ao experimento conduzido no ano anterior. A concentração de piroglutamato em alface teve crescimento significativo comparado ao ano de 2012, apresentando no tratamento com fertilização mineral e esterco de aves concentração nove vezes acima da observada nas plantas com fertilização mineral apenas, com diferença estatística entre essas concentrações. Também não foi observada diferença entre essas médias e as médias apresentadas pelos demais tratamentos. 
Foi observado que a fertilização orgânica e a mineral em mistura resultou em uma relação sinergística entre os fertilizantes em todos os tratamentos e época, com exceção da mistura com esterco ovino no período da seca.

O piroglutamato, conforme Carvalho e Machini (2013), possui ação antimicrobiana e anticancerígena, além de ser um estimulante da tireóide. Foi observado que os estercos animais proporcionaram acúmulo significativo de piroglutamato em plantas de alface, devendo esses estudos serem aprofundados para avaliar a relevância científica desta informação considerando a saúde humana.

Para o aminoácido GABA e o carboidrato Eritronato, em 2012, no estudo realizado, foi observada maior concentração nos estercos ovino e bovino, respectivamente. No entanto, considerando a normalização para o fertilizante químico, não foi observada grandes variações nas concentrações destas substâncias.

A acumulação de uma série de metabolitos solúveis é criticamente importante para o sabor e nutrição. O sabor da alface é influenciado pela quantidade de carboidratos, ácidos orgânicos, aminoácidos, lipídeos e fenóis. Os sabores e odores desagradáveis são iniciados com a respiração anaeróbia (GIMENO et al., 1995). Os ácidos orgânicos são encontrados em todas as plantas, em mínimas quantidades ou acumulando-se em determinadas espécies (RANSON, 1965). Além das diferenças entre espécies, outros fatores contribuem para alterações no conteúdo de ácidos orgânicos nas folhas das plantas (LIBERTI e FRANCESCHI, 1987).

Clark (1968) verificou que o total de ácidos orgânicos de folhas de milho deficientes em minerais foi maior do que em plantas normais e que o teor de ácido trans-aconítico decresceu em plantas deficientes em potássio. Burns et al. (1968), trabalhando com alfafa, verificou que a adubação e a maturidade das plantas provocaram alterações nos teores de ácidos orgânicos. 
Tabela 12. Compostos metabólicos encontrados em folhas de alface Lactuca sativa, cv. Vanda submetidas à fertilização orgânica e mineral no período de inverno do ano de 2012 e verão do ano de 2013 no Distrito Federal. UnB-FAV, 2016.

\begin{tabular}{|c|c|c|c|c|}
\hline Composto & Grupo & Função na planta & Função em humanos & Referência \\
\hline Alanina & Aminoácido & Processos fisiológicos em geral. & $\begin{array}{l}\text { Componente das proteínas. Suplemento nutricional } \\
\text { para atletas - força muscular e resistência. }\end{array}$ & $\begin{array}{l}\text { VOLLHARDT, } 1994 \\
\text { SOUSA e SODEK } 2002 \\
\text { CAÇO, } 2016 \\
\end{array}$ \\
\hline Homoserina & Aminoácido & $\begin{array}{l}\text { Bactérias Gram negativas usam como autoindutores do } \\
\text { Quorum sensing, (sistema de comunicação intra e } \\
\text { interespécies de microrganismos). }\end{array}$ & $\begin{array}{l}\text { Biossíntese de três aminoácidos essenciais: } \\
\text { metionina, treonina e isoleucina. }\end{array}$ & $\begin{array}{l}\text { SOLA et al., } 2012 \\
\text { BERG et al,. } 2002\end{array}$ \\
\hline GABA & Aminoácido & $\begin{array}{l}\text { Desenvolvimento vegetal, como sinalizador de processos } \\
\text { fisiológicos, quanto na defesa e em outras respostas ao } \\
\text { estresse. }\end{array}$ & $\begin{array}{l}\text { Neurotransmissor inibidor em todo o sistema } \\
\text { nervoso central. }\end{array}$ & $\begin{array}{l}\text { BOWN e SHELP } 1997 \\
\text { SNEDDEN e FROMM, } 1998\end{array}$ \\
\hline Piroglutamato & Aminoácido & $\begin{array}{l}\text { Influencia a motilidade flagelar de Pseudomonas } \\
\text { fluorescens. Bactéria promotora do crescimento vegetal. }\end{array}$ & $\begin{array}{l}\text { Ação anticancerígena e reativador da memória. } \\
\text { Neurotransmissor. Peptídeo antimicrobiano } \\
\text { mobilizado para neutralizar um amplo espectro de } \\
\text { micróbios. Estimulante da tireóide e atividade } \\
\text { hipertensiva. }\end{array}$ & $\begin{array}{l}\text { STEENHOUDT } \\
\text { VANDERLEYDEN, } 2000 \\
\text { PEDERZOLLI, 2008 } \\
\text { BORÓ et. al. (2001) } \\
\text { CARVALHO e MACHINI (2013) }\end{array}$ \\
\hline Glutamato & Aminoácido & $\begin{array}{l}\text { Atua na eficiência do metabolismo do nitrogênio e síntese } \\
\text { de clorofila e outros aminoácidos. É componente chave no } \\
\text { crescimento e funcionamento dos meristemas. }\end{array}$ & $\begin{array}{l}\text { Neurotransmissor que desempenha um papel } \\
\text { chave na potenciação de longa duração e é } \\
\text { importante para o aprendizado e a memória. }\end{array}$ & $\begin{array}{l}\text { TAIZ e ZEIGER, } 2004 \\
\text { CAÇO, } 2016 \\
\text { SAPOLSKY, } 2005 \\
\end{array}$ \\
\hline Sacarose & Carboidrato & $\begin{array}{l}\text { Os produtos oriundos da fotossíntese são translocados na } \\
\text { forma de sacarose para os órgãos de reserva. }\end{array}$ & $\begin{array}{l}\text { Fonte de energia. Regula o metabolismo protéico e } \\
\text { funcionamento normal do sistema nervoso central. }\end{array}$ & AKASAWA e OKAMOTO, 1980 \\
\hline Frutose & Carboidrato & $\begin{array}{l}\text { Produtora de energia para a maioria das células não } \\
\text { fotossintéticas }\end{array}$ & $\begin{array}{l}\text { Fonte de energia Regula o metabolismo protéico e } \\
\text { funcionamento normal do sistema nervoso central }\end{array}$ & $\begin{array}{l}\text { NELSON et al., } 2000 \\
\text { WANG e VAN EYS, } 1981 \\
\text { MALTA e GUIMARÃES, } 1976\end{array}$ \\
\hline Inositol & Carboidrato & $\begin{array}{l}\text { Via de sinalização, armazenamento e transporte de auxina. } \\
\text { Biossíntese do ácido fítico (forma utilizada pelas plantas } \\
\text { para armazenamento de fósforo, no entanto, não é uma } \\
\text { fonte de fósforo nem nos humanos nem nos animais não } \\
\text { ruminantes), síntese da parede celular e produção de } \\
\text { moléculas relacionadas com o estresse. }\end{array}$ & $\begin{array}{l}\text { Atua como fator de crescimento nutrição das } \\
\text { células cerebrais transmissão de mensagens entre } \\
\text { células neurais e o transporte de gorduras dentro } \\
\text { das células. }\end{array}$ & $\begin{array}{l}\text { MERCK INDEX, 2016; } \\
\text { CLEMENTS e DARNELL, } 1980 \\
\text { HOLUB, } 1982 \\
\text { PARTHASARATHY e EISENBERG, } \\
1986\end{array}$ \\
\hline Galactose & Carboidrato & $\begin{array}{lccc}\text { Constituinte importante dos } & \text { glicolipídos, } & \text { dos } \\
\text { proteoglicanos e das glicoproteínas. } & & \\
\end{array}$ & Fonte de energia. & $\begin{array}{l}\text { BOBBIO e BOBBIO, } 2005 \\
\text { MARQUES, } 2015 \\
\text { RAVEN e JOHNSON } 1995\end{array}$ \\
\hline Glicerato & Carboidrato & Atua no sistema fotorrespiratório. & - & VIEIRA et al., 2010 \\
\hline Treonato & Carboidrato & - & Metabólito do ácido ascórbico & ENGLARD e SEIFTER, 1986 \\
\hline
\end{tabular}




\begin{tabular}{|c|c|c|c|c|}
\hline Eritronato & Carboidrato & - & Derivada da degradação do ácido ascórbico & JAHN et al., 1999 \\
\hline Glucopiranose & Carboidrato & $\begin{array}{l}\text { Um dos principais produtos da fotossíntese e inicia a } \\
\text { respiração. }\end{array}$ & - & CRC, 2009 \\
\hline Citrato & Ácido orgânico & Intermediário do ciclo do ácido cítrico. Respiração celular & - & NELSON e COX, 2002 \\
\hline Malato & Ácido orgânico & $\begin{array}{l}\text { Processo de fixação do carbono pela via } \mathrm{C} 4 \text {. Fonte de } \\
\mathrm{CO}_{2} \text { no ciclo de Calvin }\end{array}$ & $\begin{array}{l}\text { Higienização e regeneração de ferimentos } \mathrm{e} \\
\text { queimaduras }\end{array}$ & JENSEN, 2007 \\
\hline Fumarato & Ácido orgânico & Respiração de tecidos. & $\begin{array}{l}\text { Agente flavorizante para dar sabor a sobremesas e } \\
\text { proporcionar ação antioxidante. }\end{array}$ & DE SOUZA, 2016 \\
\hline Succinato & Ácido orgânico & $\begin{array}{l}\text { Produto do ciclo de Krebs (isocitrato é convertido em } \\
\text { succinato). Produto do ciclo do glioxilato (isocitrato } \\
\text { origina o succinato e o glioxilato). }\end{array}$ & $\begin{array}{l}\text { Matéria-prima para fabricação de antibióticos e } \\
\text { vitaminas }\end{array}$ & $\begin{array}{l}\text { BELTRÃO e OLIVEIRA, } 2007 \\
\text { ZEIKUS e JAIN, } 1999 \\
\text { BORGES, } 2011 \\
\text { SONG e LEE, } 2006\end{array}$ \\
\hline $\begin{array}{l}\text { Ácido } \\
\text { glicólico }\end{array}$ & Ácido orgânico & Atua no processo fotorrespiratório & Utilizado em produtos para a pele & $\begin{array}{l}\text { VIEIRA et al, } 2010 \\
\text { ALMEIDA, } 2008\end{array}$ \\
\hline Malonato & Ácido orgânico & $\begin{array}{l}\text { Rota do ácido malônico - menos significativa nas plantas } \\
\text { superiores }\end{array}$ & - & YAMADA, 2004 \\
\hline Gulonato & Ácido orgânico & - & $\begin{array}{l}\text { Fabricação do ácido ascórbico no fígado a partir da } \\
\text { simples glicose }\end{array}$ & LE COUTEUR, 2006 \\
\hline Ácido quínico & Ácido orgânico & Percepção de acidez do café & - & SANTOS et al., 2011 \\
\hline Glicerol & Álcool & $\begin{array}{l}\text { Precursor de numerosos compostos e como regulador de } \\
\text { vários mecanismos bioquímicos intracelulares }\end{array}$ & $\begin{array}{l}\text { Termo-regulação do corpo, resistência a altas } \\
\text { temperaturas, na resistência dos músculos em } \\
\text { atividades físicas e na resposta neural da variação } \\
\text { da glicemia. }\end{array}$ & $\begin{array}{l}\text { LAGES et al., } 1997 \\
\text { RIVALDI et al. } 2008 \\
\text { WANG et al., } 2001 \\
\text { YANG et al., } 1999\end{array}$ \\
\hline Ácido caféico & Ácido fenólico & Intermediário fundamental na biossíntese da lenhina & $\begin{array}{l}\text { Propriedades antioxidantes (quer in vitro, como in } \\
\text { vivo), bem como propriedades imunomoduladoras } \\
\text { e anti-inflamatórias }\end{array}$ & $\begin{array}{l}\text { GULÇIN, } 2006 \\
\text { SOARES, } 2002\end{array}$ \\
\hline
\end{tabular}


Tabela 13. Teste F para os metabólitos encontrados por comparação de índices de espectros de massas (GC-MS) em folhas de alface Lactuca sativa, cv. Vanda, sob fertilização orgânica e mineral no período de inverno do ano de 2012 e verão do ano de 2013 no Distrito Federal. UnB-FAV, 2016.

\begin{tabular}{|c|c|c|c|c|c|}
\hline Metabólito & $\begin{array}{c}2012 \\
\text { Inverno }\end{array}$ & $\begin{array}{c}2013 \\
\text { Verão }\end{array}$ & $\mathbf{F}$ & Sig. & Alteração\% \\
\hline Ácido Glicólico & 1,1747 & 2,0474 & 09,349 & $0,007 *$ & 174,29 \\
\hline Alanina & 1,0929 & 1,8340 & 10,780 & $0,004 *$ & 167,81 \\
\hline Malonato & 1,1282 & 1,2810 & 0,432 & 0,520 & 113,54 \\
\hline Glicerol & 0,9194 & 1,3709 & 36,569 & $0,000 *$ & 149,10 \\
\hline Succinato & 0,9803 & 1,7932 & 24,616 & $0,000 *$ & 182,92 \\
\hline Glicerato & 0,6913 & 1,1240 & 31,265 & $0,000^{*}$ & 162,59 \\
\hline Fumarato & 0,6714 & 1,0383 & 6,731 & $0,018^{*}$ & 154,64 \\
\hline Malato & 0,8629 & 1,5799 & 17,806 & $0,001 *$ & 183,09 \\
\hline Piroglutamato & 2,8542 & 4,7650 & 5,940 & $0,025^{*}$ & 166,94 \\
\hline P-Homoserina & 0,9628 & 1,0702 & 1,481 & 0,239 & 111,15 \\
\hline Gaba & 0,9925 & 1,0092 & 1,200 & 0,288 & 101,68 \\
\hline Eritronato & 0,9832 & 1,6024 & 23,481 & $0,000 *$ & 162,97 \\
\hline Treonato & 1,1027 & 1,7404 & 14,610 & $0,001 *$ & 157,83 \\
\hline Glutamato & 1,0235 & 2,1859 & 20,557 & $0,000 *$ & 213,57 \\
\hline Citrato & 1,0940 & 1,4374 & 10,288 & $0,005^{*}$ & 131,38 \\
\hline Frutose & 0,8455 & 1,0241 & 28,534 & $0,000 *$ & 121,12 \\
\hline Ác. Quinico & 0,8809 & 1,2398 & 16,812 & $0,001 *$ & 140,74 \\
\hline Galactose & 0,9260 & 0,9817 & 0,541 & 0,471 & 106,01 \\
\hline myo-Inositol & 0,9232 & 0,9889 & 0,572 & 0,459 & 107,11 \\
\hline Glucopiranose & 0,2716 & 4,1400 & 33,567 & $0,000 *$ & 152,43 \\
\hline Gulonato & 0,9866 & 1,5526 & 11,419 & $0,003^{*}$ & 157,36 \\
\hline Ácido Caféico & 0,8633 & 1,4776 & 8,456 & $0,009 *$ & 171,15 \\
\hline Sacarose & 1,1996 & 5,8353 & 2,460 & 0,134 & 486,43 \\
\hline
\end{tabular}

*Amostras significativas a 5\% pelo Teste $\mathrm{F}$. 
Tabela 14. Metabólitos em folhas de alface, Lactuca sativa, cv. Vanda, sob fertilização orgânica e mineral no período de inverno do ano de 2012 no Distrito Federal. UnB-FAV, 2016.

\begin{tabular}{ccccccccccc}
\hline $\begin{array}{c}\text { Metabólito/ } \\
\text { Fertilização }\end{array}$ & Químico* & Bovino & Ovino & Aves & $\begin{array}{c}\text { Composto } \\
\text { Orgânico }\end{array}$ & $\begin{array}{c}\text { Químico+ } \\
\text { Bovino }\end{array}$ & $\begin{array}{c}\text { Químico+ } \\
\text { Ovino }\end{array}$ & $\begin{array}{c}\text { Químico+ } \\
\text { Aves }\end{array}$ & $\begin{array}{c}\text { Químico+ } \\
\text { Cama de } \\
\text { Frango }\end{array}$ & $\begin{array}{c}\text { Cama } \\
\text { Frango } \\
\text { de }\end{array}$ \\
\hline Piroglutamato & $1,000 \mathrm{a}$ & $2,158 \mathrm{ab}$ & $2,303 \mathrm{ab}$ & $3,170 \mathrm{ab}$ & $3,015 \mathrm{ab}$ & $4,020 \mathrm{ab}$ & $1,694 \mathrm{ab}$ & $3,896 \mathrm{ab}$ & $4,949 \mathrm{~b}$ & $2,356 \mathrm{ab}$ \\
GABA & $1,000 \mathrm{ab}$ & $0,930 \mathrm{ab}$ & $0,921 \mathrm{a}$ & $0,993 \mathrm{ab}$ & $1,017 \mathrm{ab}$ & $0,971 \mathrm{ab}$ & $1,068 \mathrm{~b}$ & $1,002 \mathrm{ab}$ & $1,008 \mathrm{ab}$ & $1,002 \mathrm{ab}$ \\
Eritronato & $1,000 \mathrm{ab}$ & $0,624 \mathrm{a}$ & $0,937 \mathrm{ab}$ & $1,032 \mathrm{ab}$ & $1,257 \mathrm{~b}$ & $0,890 \mathrm{ab}$ & $1,074 \mathrm{ab}$ & $0,834 \mathrm{ab}$ & $1,182 \mathrm{ab}$ & $1,046 \mathrm{ab}$ \\
\hline
\end{tabular}

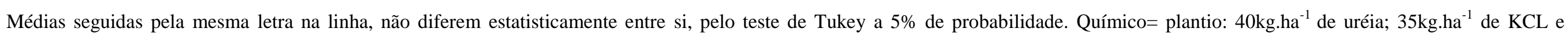

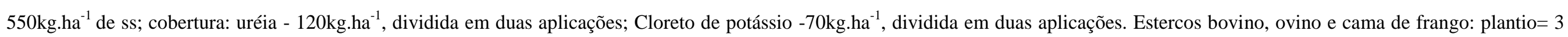
$\mathrm{kg} \cdot \mathrm{m}^{-2}$ cobertura $=2 \mathrm{~kg} \cdot \mathrm{m}^{-2}$. Esterco de aves: plantio $1,5 \mathrm{~kg} \cdot \mathrm{m}^{-2}$, cobertura $=; 0,5 \mathrm{~kg} \cdot \mathrm{m}^{-2}$. Composto orgânico: $\mathrm{plantio}=0,5 \mathrm{~kg} \cdot \mathrm{m}^{-2}$, cobertura $=0,5 \mathrm{~kg} \cdot \mathrm{m}^{-2}$.

* Concentrações normalizadas pelo tratamento com fertilização química. 
O período de fevereiro a abril de 2013 foi caracterizado como período de chuvas na região do experimento (Tabela 15). Houve diferença estatística entre os tratamentos para a concentração de algumas substâncias presentes em plantas de alface. A presença de ácido glicólico foi superior em plantas adubadas com cama de frango e inferior em plantas adubadas com o fertilizante mineral, com diferença estatística entre as concentrações. Não houve diferença estatística entre a concentração observada com fertilização mineral e os demais estercos animais e o composto. A substância sofreu incremento com as misturas de fertilizantes utilizadas em 2013. Porém, a variação de concentração foi tímida considerando o ocorrido com piroglutamato.

A concentração de malonato foi significativamente superior em plantas adubadas com fertilizante mineral e cama de frango e significativamente inferior em plantas adubadas com esterco ovino. O succinato, esteve mais presente em folhas com fertilizante mineral e esterco de aves e em menor concentração em amostras com fertilização mineral. Houve diferença estatística entre esses dois tratamentos. No entanto, não foi observada diferença estatística entre os demais tratamentos para a concentração de succinato. $\mathrm{O}$ malato foi significativamente superior em amostras adubadas com fertilização mineral e esterco de aves e inferior em amostras adubadas com fertilização mineral apenas. A quantidade de gulonato foi superior em plantas adubadas com fertilização mineral e esterco de aves do que em plantas adubadas com cama de frango. O ácido caféico foi encontrado em quantidades significativamente maiores em plantas adubadas com esterco bovino e menor em plantas adubadas com cama de frango.

A presença destes compostos confere características desejáveis para as plantas de alface submetidas aos diferentes tratamentos de fertilização. Com raras exceções a fertilização orgânica proporcionou incremento na concentração de aminoácidos, ácidos orgânicos e carboidratos. Embora, os resultados sejam animadores, são necessários estudos mais aprofundados para confirmar o incremento destas substâncias em vegetais que se desenvolvem sob fertilização orgânica e a vinculação deste incremento com efeitos positivos na saúde humana.

Wang et al. (2015) analisaram o perfil metabólico de rabanetes expostos ao chumbo $(\mathrm{Pb})$ e cádmio $(\mathrm{Cd})$ utilizando a técnica GC-MS para avaliar as alterações sofridas pelos metabólitos, principalmente açúcares, aminoácidos e ácidos orgânicos sob estresse. A análise dos dados demonstrou que a exposição de rabanete ao $\mathrm{Pb}$ resultou em profundas alterações bioquímicas incluindo o metabolismo de carboidratos, e metabolismo da 
glutationa, enquanto o tratamento com $\mathrm{Cd}$ causou variações significativas na produção de energia, no metabolismo de aminoácidos e vias oxidativas relacionadas com a fosforilação. Os autores identificaram 34 metabólitos, entre eles, três compostos eram desconhecidos, e um composto era de um tipo de esteróides que não pode ser identificado com precisão. Os metabólitos alterados foram principalmente aqueles envolvidos no metabolismo primário da glicólise e o ciclo de ácido cítrico e os metabólitos de ligação à síntese de aminoácidos. A acumulação de gluconato foi potencializada nos dois tratamentos, enquanto diminuições no conteúdo de cinco açúcares (maltose, inositol, turanose, $\alpha$-D-glucopiranósido e $\beta$-Dglucopiranose), dois aminoácidos (alanina e glicina), três ácidos orgânicos (ácido acetimídico, ácido decanóico e ácido oxálico), glicerol, hidroxilamina, ácido fosfórico e do sitosterol foram identificadas. No entanto, o conteúdo de três açúcares (frutose, galactose e glucose), três ácidos orgânicos (citrato, ácido hexadecanóico e ácido octadecanóico), e um tipo de esteróide aumentaram em resposta no tratamento com $\mathrm{Pb}$, mas diminuiu no tratamento com Cd. Uma diminuição do conteúdo de malato, serina e isoleucina foram identificadas no tratamento com $\mathrm{Pb}$, enquanto que não foi detectada nenhuma diferença significativa no conteúdo destes metabólitos após a exposição ao Cd. Em contraste,os níveis de $\alpha$-D-glucopiranósido, prolina, treonina, piroglutamato, 4-aminobutirato, pirofosfato, ácido nicotínico, colesterol, monoestearina e dois compostos desconhecidos foram reduzidos no tratamento com $\mathrm{Cd}$, em vez de exposição ao $\mathrm{Pb}$.

No trabalho realizado por $\mathrm{Xu}$ et al., (2016), duas cultivares de Camellia sinensis (L.), popularmente conhecida como chá da índia, planta hiperacumuladora de alumínio, foram tratadas com diferentes concentrações de $\mathrm{Al}{ }^{3+}$. Foram detectadas alterações metabólicas nas duas variedades usando o GC-MS. A comparação entre as duas cultivares indicou que a via chiquímico foi melhorada em mais raízes da cultivar $\mathrm{YS}_{\text {por }} \mathrm{Al}^{3+}$ com níveis mais elevados de catequina, ácido quínico e ácido chiquímico. A cultivar JHC manteve o conteúdo mais elevado de metabólitos relacionados com a síntese de cisteína. A comparação também mostrou que uma grande quantidade de álcoois de açúcar eram acumulados nas raízes das duas variedades, ao passo que a maioria deles foi reduzida em folhas da cultivar YS. O ácido fosfórico e o malato foram observados nas duas cultivares que mostraram aumento significativo nos tratamentos com $\mathrm{Al}^{3+}$. Os resultados indicaram que a adaptação das duas cultivares ao $\mathrm{Al}^{3+}$ podem estar correlacionadas com o seu metabolismo diferencial de aminoácidos, açúcares e ácido chiquímico. 
De acordo com Van Hees et al. (2000), no solo são encontrados os ácidos oxálico, cítrico, fórmico, acético, málico, succínico, maleico, acotínico, fumárico, gálico, vanílico, benzóico, fumárico e chiquímico, em concentrações variáveis. Em resíduos vegetais a presença dos ácidos oxálico, tartárico, acotínico, málico, cítrico, acético, lático, ascórbico e fórmico são comuns, havendo predominância, de acordo com o resíduo analisado, dos ácidos acotínico, cítrico e málico (SINGH e AMBERGER, 1998; XU et al., 2006). Guppy et al. (2005) afirma que os compostos orgânicos do solo são formados por ácidos húmicos e fúlvicos, ácidos orgânicos de baixa massa molecular (AO), ácido tânico, aminas, compostos aromáticos, dentre outros, e que podem fazer parte do $\mathrm{C}$ orgânico solúvel do solo. Na solução do solo, a concentração normal de C orgânico solúvel varia de 0,2 a 2,5 mmol L-1. A concentração de AO no tecido das plantas é de 10 a 100 vezes maior que a encontrada no solo, em virtude da sua ação nos processos metabólicos celulares. 
Tabela 15. Metabólitos em folhas de alface, Lactuca sativa, cv. Vanda, sob fertilização orgânica e mineral no período de verão do ano de 2013 no Distrito Federal. UnB-FAV, 2016.

\begin{tabular}{|c|c|c|c|c|c|c|c|c|c|c|}
\hline & Químico & Bovino & Ovino & Aves & Composto & $\begin{array}{c}\text { Químico+ } \\
\text { Bovino }\end{array}$ & $\begin{array}{l}\text { Químico+ } \\
\text { Ovino }\end{array}$ & $\begin{array}{c}\text { Químico+ } \\
\text { Aves }\end{array}$ & $\begin{array}{l}\text { Químico+ } \\
\text { Cama }\end{array}$ & $\begin{array}{c}\text { Cama de } \\
\text { Frango }\end{array}$ \\
\hline Ác. Glicólico & $1,000 \mathrm{a}$ & $1,826 \mathrm{a}$ & $1,704 \mathrm{a}$ & $1,381 \mathrm{a}$ & $1,461 \mathrm{a}$ & $2,347 \mathrm{ab}$ & $1,978 \mathrm{ab}$ & $2,744 \mathrm{ab}$ & $1,904 a$ & $4,125 b$ \\
\hline Malonato & $1,000 \mathrm{ab}$ & $2,105 b c$ & $0,894 \mathrm{ab}$ & $0,945 \mathrm{ab}$ & 0,899ab & $0,718 \mathrm{a}$ & $0,760 \mathrm{ab}$ & $1,355 \mathrm{ab}$ & $2,821 \mathrm{c}$ & $1,308 \mathrm{ab}$ \\
\hline Succinato & $1,000 \mathrm{a}$ & $2,351 \mathrm{ab}$ & $1,937 \mathrm{ab}$ & 1,859ab & $2,382 \mathrm{ab}$ & $1,344 \mathrm{ab}$ & $1,344 \mathrm{ab}$ & $2,484 b$ & $1,773 \mathrm{ab}$ & $1,320 \mathrm{ab}$ \\
\hline Malato & $1,000 \mathrm{a}$ & 1,599ab & $1,735 \mathrm{ab}$ & $1,597 \mathrm{ab}$ & 1,299ab & $1,297 \mathrm{ab}$ & $1,372 \mathrm{ab}$ & $2,928 b$ & $1,493 \mathrm{ab}$ & $1,476 \mathrm{ab}$ \\
\hline Piroglutamato & $1,000 \mathrm{a}$ & $5,527 \mathrm{ab}$ & $3,108 \mathrm{ab}$ & $3,976 \mathrm{ab}$ & $3,515 \mathrm{ab}$ & $5,142 \mathrm{ab}$ & $6,364 \mathrm{ab}$ & $9,234 b$ & $5,079 \mathrm{ab}$ & $3,976 \mathrm{ab}$ \\
\hline Gulonato & $1,000 \mathrm{a}$ & 1,973ab & $1,451 \mathrm{ab}$ & $2,013 \mathrm{ab}$ & $1,281 \mathrm{ab}$ & $1,391 \mathrm{ab}$ & 1,296ab & $2,563 b$ & $1,578 \mathrm{ab}$ & $0,976 \mathrm{a}$ \\
\hline Ác. Caféico & $1,000 \mathrm{ab}$ & $2,361 b$ & $1,398 \mathrm{ab}$ & $1,511 \mathrm{ab}$ & $1,759 \mathrm{ab}$ & $1,297 \mathrm{ab}$ & $1,334 \mathrm{ab}$ & $2,130 \mathrm{ab}$ & $1,565 \mathrm{ab}$ & $0,417 \mathrm{a}$ \\
\hline
\end{tabular}

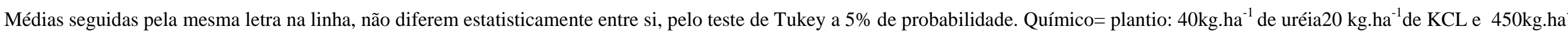

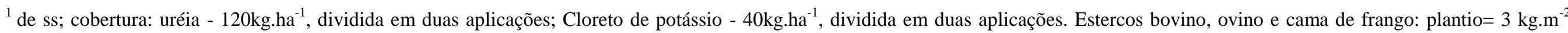
cobertura $=2 \mathrm{~kg} \cdot \mathrm{m}^{-2}$. Esterco de aves: plantio $1,5 \mathrm{~kg} \cdot \mathrm{m}^{-2}$, cobertura $=; 0,5 \mathrm{~kg} \cdot \mathrm{m}^{-2}$. Composto orgânico: plantio= $0,5 \mathrm{~kg} \cdot \mathrm{m}^{-2}$, cobertura $=0,5 \mathrm{~kg} \cdot \mathrm{m}^{-2}$.

* Concentrações normalizadas pelo tratamento com fertilização química. 
No tomate, o sabor da fruta é influenciado tanto pelos metabólitos voláteis como pelos não-voláteis (BUTTERY et al, 1987; GOFF e KLEE, 2006; CARLI et al., 2009). Dos metabolitos não voláteis, o equilíbrio entre açúcares e compostos ácidos é de grande importância para o sabor (TIEMAN et al., 2012). Uma análise de vários genótipos demonstrou uma forte correlação entre o sabor do fruto de tomate e os principais metabolitos ácidos como os ácidos carboxílicos, Glu e Asp (CARLI et al., 2009). Os ácidos carboxílicos são um dos principais componentes do potencial osmótico que dirige a expansão das células através da absorção de água na fase de expansão de crescimento do fruto (LIU et al., 2003). As concentrações de citrato e outros ácidos carboxílicos são reduzidas durante esta fase de expansão à medida que o conteúdo da célula é diluído (BAXTER et al., 2005; CARRARI et al., 2006). Durante as fases finais de maturação, o nível de citrato e, em menor medida, de outros ácidos carboxílicos, aumenta novamente de tal forma que este se encontra em grande abundância no fruto maduro. As atividades catalíticas máximas de enzimas do ácido tricarboxílico geralmente diminui durante o desenvolvimento dos frutos, e não há alterações acentuadas nas atividades durante os últimos estágios de maturação que se correlacionam com o aumento dos níveis de ácidos orgânicos (STEINHAUSER et al., 2010).

Silva et al. (2011) avaliou a qualidade da alface do grupo crespa, cv. Vera, em sistemas de cultivo orgânico, convencional e hidropônico em Rio Branco-AC. As amostras dos sistemas, convencional e hidropônico de três marcas comerciais, foram escolhidas aleatoriamente nos supermercados no mesmo dia de coleta da alface produzida em sistema orgânico cultivada em estufa, sob plantio direto, utilizando folhas de bambu como cobertura do solo, e adubada com composto orgânico (17 $\mathrm{t} \mathrm{ha}^{-1} \mathrm{em}$ base seca). As três marcas de alface hidropônica apresentaram maior teor de nitrato e menor concentração de sólidos solúveis e ácido ascórbico, enquanto a alface orgânica apresentou qualidade superior, com baixa concentração de nitrato e maior teor de ácido ascórbico.

$\mathrm{Na}$ literatura não foram encontrados relatos de caracterização de metabólitos em plantas de alface relacionados à diferentes fontes de fertilização. Os experimentos conduzidos na Fazenda Água Limpa nos anos de 2012 e 2013 auxiliam na compreensão de como a fertilização pode influenciar o acúmulo de substâncias em folhas de alface. Os metabólitos identificados estão em sua grande maioria no grupo dos aminoácidos, carboidratos e ácidos orgânicos e sua concentração na planta de alface sofreu influência da origem do fertilizante utilizado, mineral, compostado ou estercos animais, bem como sofreu influência das condições climáticas, evidenciando incremento no período de verão. 


\section{CONCLUSÕES}

Considerando as condições em que os experimentos foram realizados, as hipóteses e objetivos inicialmente propostos, verificou-se que:

- Plantas de alface cv. Vanda fertilizadas com estercos animais apresentaram desempenho agronômico igual ou superior àquelas fertilizadas com fertilizantes minerais.

- Não houve contaminação da alface cv. Vanda pelos metais pesados, cádmio e chumbo, e nem pelos microrganismos patogênicos, Salmonella spp e coliformes termotolerantes, quando da utilização de estercos animais e composto orgânico.

- A concentração dos pigmentos fotossintéticos (clorofila $a$, clorofila $b$, clorofila total e carotenóides) apresentou comportamento similar sob fertilização orgânica e mineral.

- Os estercos, notadamente o esterco de aves, ovinos e a cama de frango, proporcionaram os maiores acúmulos de aminoácidos, carboidratos e ácidos orgânicos em plantas de alface cv. Vanda.

- O aminoácido piroglutamato, relatado como anticancerígeno e antimicrobiano, teve sua concentração em alface cv. Vanda incrementada com a utilização de fertilizantes orgânicos.

Portanto, a fertilização orgânica vem se confirmar como uma importante ferramenta de suporte à produção de folhosas, contribuindo para o incremento da produção e da qualidade do produto agrícola. 


\section{CONSIDERAÇÕES FINAIS}

A produção e o consumo de alimentos constituem em preocupação cada dia mais evidente na sociedade. A preservação do meio ambiente e a melhoria da qualidade de vida influenciam as percepções e decisões da vida cotidiana. A aquisição de alimentos, antes realizada de forma inconsciente, tornou-se alvo de maior atenção, principalmente, considerando a escolha do alimento e a relação com a saúde.

A qualidade de um alimento precisa ser analisada sob diferentes dimensões para que possa dar indicativos da melhor opção de escolha para os produtores, auxiliando na decisão do que plantar, como plantar e para quem plantar e, também, para os consumidores, auxiliando-o na escolha do melhor produto a ser adquirido e consumido.

No presente trabalho várias características quantitativas e qualitativas da alface foram avaliadas buscando auxiliar no processo decisório dos atores da cadeia de produção de alface e outras folhosas.

Os resultados observados quanto aos pigmentos fotossintéticos e perfil metabólico colocam em evidência o efeito da adubação orgânica sobre aspectos de qualidade da cultura da alface cv. Vanda. Novos estudos nesta mesma linha poderão contribuir para elucidação de como os estercos animais e compostos orgânicos interferem na fisiologia e metabolismo da alface e outras folhosas. 


\section{REFERÊNCIA}

ABREU, I. M. de O.; JUNQUEIRA, A. M. R.; PEIXOTO, J. R.; OLIVEIRA, S. A. de. Qualidade microbiológica e produtividade de alface sob adubação química e orgânica. Ciênc. Tecnol. Aliment. [online]., vol.30, suppl.1, p.108-118, 2010.

AKASAWA, T.; K. OKAMOTO. Biosynthesis and metabolism of sucrose. In: PREISS, J. (ed.), The Biochemistry of Plants. Vol. 3. Acad. Press, New York, 1980. 644 p.

ALMEIDA, E.F. Utilização do acido glicólico nas alterações estéticas. Revista Personalité. São Paulo, v.11. n.56, p.124-135p, mar/abr, 2008.

ALTIERI, M.A., NICHOLLS, C.I. Agroecology and the Search for a Truly Sustainable Agriculture. 1st edition. University of California, Berkeley. First edition: 2005. 291p.

ALVARENGA, A.A. de. Respiração - Apostila. Universidade Federal de Lavras. Departamento de Biologia. Setor de Fisiologia Vegetal. Lavras - MG. 2004. Disponível em: www.dbi.ufla.br/amauri/Respiracao/RESPIRAÇÃO_Amauri.doc. Acesso em: 12 de março de 2016.

ALVES, F. R. R. Respostas bioquímicas e fisiológicas de mutantes fotomorfogenéticos de tomateiro (Solanum lycopersicum L. cv. Micro-Tom) sob deficiência hídrica. 2015. $73 \mathrm{f}$. Dissertação (Mestrado em Biodiversidade Vegetal) - Universidade Federal de Goiás, Goiânia, 2015.

ALVES, S.L. da C., NEVES, M.C.P., COSTA, J.R. Avaliação da contaminação microbiológica de alface orgânica e convencional em diferentes pontos de comercialização. Embrapa Agrobiologia. Comunicado Técnico 105. 4p. 2007.

AMARO, A.C.E. Respostas fisiológicas à aplicação de reguladores vegetais e nutrientes em videira 'CRIMSON SEEDLESS'. Abril de 2014. 129p. Tese de Doutorado. Faculdade de Ciências Agronômicas da UNESP - Campus de Botucatu. Botucatu, 2014.

AMMOR, M. S.; MICHAELIDIS, C.; NYCHAS, G. J. Insights into the role of quorum sensing in food spoilage. Journal of Food Protection, Des Moines, v. 71, n. 7, p. 1510-1525, jul./2008.

ANDRADE, M. F. DE.; MORAES, L. R. S. Contaminação por chumbo em Santo Amaro desafia décadas de pesquisas e a morosidade do poder público. Ambient. soc. vol.16 no.2 São Paulo Apr./June, 2013.

ARBOS, K. A. ; FREITAS, R. J. S. de; STERTZ, S. C. ; CARVALHO, L. A. Segurança alimentar de hortaliças orgânicas: aspectos sanitários e nutricionais. Ciênc. Tecnol. Aliment., Campinas, 30(Supl.1): p.215-220, maio de 2010.

ASSOCIATION OF OFFICIAL ANALYTICAL CHEMISTS. Bacteriological Analytical Manual, 6.ed. Estados Unidos: Food and Drug Administration, 1984. 946p. 
AZEVEDO, E. Alimentos Orgânicos: ampliando conceitos de saúde humana, ambiental e social. Tubarão: Editora Unisul, 2005. 268p.

AZIZ, N.H., FARAG, S.E., MOUSA, L.A., ABO-ZAID, M.A. Comparative antibacterial and antifungal effects of some phenolic compounds. Microbios, Cambridge, v.93, n.374, p.43-54, 1998.

BADUE, A.F.B. Inserção de hortaliças e frutas orgânicas na merenda escolar: as potencialidades da participação e as representações sociais de agricultores de Parelheiros, São Paulo. Universidade de São Paulo, Faculdade de Saúde Pública. São Paulo, 2007. 265p. Dissertação (Mestrado em Saúde Pública) - Faculdade de Saúde Pública, Universidade de São Paulo, São Paulo.

BAILEY, J.S., COX, N.A., BLANKENSHIP, L.C. A comparison of an enzyme immunoassay, DNA hybridization, antibody immobilization, and conventional methodos for recovery of naturally occurring salmonellae from processed broiler carcasses. Journal of Food Protection, v. 54, p. 354, 1991.

BARBIERI, E. Pesticidas: um problema grave de saúde pública e ambiental. Disponível em: http://www.abdl.org.br/article/view/2683/1/152. Acesso em: 04 de novembro de 2006.

BARREIROS, R.C.; BOSSOLAN, G.; TRINDADE, C.E.P. Frutose em humanos: efeitos metabólicos, utilização clínica e erros inatos associados. Rev. Nutr., Campinas, 18(3), p.377389, maio/jun., 2005.

BARROS, L. E; FERREIRA DOS SANTOS, J.E.; DOS SANTOS MOREIRA, I., CORDEIRO DE SOUSA, F., SOUSA NUNES, J. Qualidade microbiológica de frutas e hortaliças comercializadas na cidade de Juazeiro do Norte-CE. Revista Verde de Agroecologia e Desenvolvimento Sustentável, v. 8, n.3, p.23-26, 2013.

BARTZ, S. Contaminação microbiológica e avaliação da segurança de alface na produção primária e varejo. 2015. 104p. Tese de Doutorado. Universidade Federal do Rio Grande do Sul. Instituto de Ciências e Tecnologia de Alimentos. Programa de Pós-Graduação em Ciência e Tecnologia de Alimentos. Porto Alegre, RS. 2015.

BATISTA., M. A. V.; VIEIRA, L. A.; SOUZA, J. P. DE; FREITAS, J. D. B.; NETO, F. B. Efeito de diferentes fontes de adubação sobre a produção de Alface no município de Iguatuce. Revista Caatinga, Mossoró, v. 25, n. 3, p. 8-11, jul-set, 2012.

BAXTER, C.J.; CARRARI, F.; BAUKE, A.; OVERY,S.; HILL, S.A.; QUICK, P.W.; FERNIE, A.R.; SWEETLOVE, L.J. Fruit carbohydrate metabolism in an introgression line of tomato with increased fruit soluble solids. Plant Cell Physiol 46, p.425-437. 2005.

BEATRIZ, A.; J. K. ARAÚJO, Y.J.K.; DE LIMA, D.P. Glicerol: um breve histórico e aplicação em sínteses estereosseletivas. Quim. Nova, v. 34, n. 2, p.306-319, 2011.

BECK, E.; H. HOPF. Carbohydrate Metabolism. Progress In Botany v.44, p.132-153. 1982. 
BELTRÃO, N.E.de M.; OLIVEIRA, M.I.P. de. Biossíntese e Degradação de Lipídios, Carboidratos e Proteínas em Oleaginosas. Embrapa Algodão. Documentos, 178. Campina Grande- PB. 2007. 61p.

BENEVIDES, S. D., RAMOS, A. M., PEREZ, R. Necessidade da implementação da rastreabilidade como ferramenta de qualidade para a industrialização da manga na zona da mata mineira. R. Bras. Agrociência, Pelotas, v.13, n.1, p.19-24, jan-mar, 2007.

BERG, J.M.; STRYER, L.; TYMOCZKO, L.S. Biochemistry. New York: WH Freeman. 2002. 1044p.

BIZZO, A.L.T. Avaliações ecofisiológicas e estruturais em Eichhornia crassipes (Mart.) Solms submetida a Cr+3 .2015. 54p. Dissertação de mestrado em Ecologia e Recursos Naturais. Centro de Biociências e Biotecnologia da Universidade Estadual do Norte Fluminense "Darcy Ribeiro". 2015.

BOBBIO, F. O.; BOBBIO, P. A. Química de Alimentos. São Paulo: Varela, 2005. 238p.

BONILLA, J.A. A gestão da qualidade total na agropecuária: aspectos introdutórios. Revista Eletrônica de Ciência Administrativa, v.2, n.2,p. 1-17, nov, 2003.

BORGES, E. R. Desenvolvimento e um Processo Biotecnológico para Produção de Ácido Succínico por Actinobacillus succinogenes. 2011. 226p. Tese (Doutorado em Ciências) Universidade Federal do Rio de Janeiro - UFRJ, Escola de Química, Programa de PósGraduação em Tecnologia de Processos Químicos e Bioquímicos. - Rio de Janeiro, 2011.

BORÓ, L.; JIMÉNEZ, J.; MARTINEZ-FÉREZ, A.; BOZA, J.J. Peptidos y proteínas de la leche com propiedades funcionales. Ars. Pharmaceutica, v.42, n. 3-4, p.135-145, 2001.

BOURN, D.; PRESCOTT, J. A Comparison of the nutritional value, sensory qualities and food safety of organically and conventionally produced foods. Crit Rev Food Sci Nutr. v.42, n.1, p. 1-34, 2002.

BOWN, A.W. \& SHELP, B.J. The metabolism and functions of g-aminobutyric acid. Plant Physiol., v.115, p. 1-5. 1997.

BRASIL. Ministério da Agricultura, Pecuária e Abastecimento. Produtos orgânicos : o olho do consumidor / Ministério da Agricultura, Pecuária e Abastecimento. Secretaria de Desenvolvimento Agropecuário e Cooperativismo. - Brasília : MAPA/ACS, 2009.

BRASIL.- Ministério da Agricultura, Pecuária e Abastecimento. Regulamento Técnico para os Sistemas Orgânicos de Produção, bem como as listas de substâncias e práticas permitidas para uso nos Sistemas Orgânicos de Produção. Instrução Normativa $N^{\circ} 46$, de 6 de Outubro de 2011.

BRASIL. Ministério da Saúde. Secretaria de Vigilância Sanitária- SVS/MS. Regulamento Técnico: Princípios Gerais para o Estabelecimento de Níveis Máximos de Contaminantes Químicos em Alimentos e seu Anexo: "Limites máximos de tolerância para contaminantes 
inorgânicos complementa e faz algumas modificações no Decreto Lei $\mathrm{n}^{\circ} 55.871$, de 26 de março de 1965. Portaria nº. 685, de 27 de Agosto de 1998.

BRASIL. Ministério da Saúde. Agência Nacional de Vigilância sanitária. Regulamento técnico sobre padrões microbiológicos para alimentos. Resolução RDC $\mathrm{n}^{\circ} 12$, de 02 de janeiro de 2001.

BRASIL. Ministério da Agricultura, Pecuária e Abastecimento. Secretaria de Defesa Agropecuária. Oficializar os Métodos Analíticos Oficiais para Análises Microbiológicas para Controle de Produtos de Origem Animal e Água. Instrução Normativa N ${ }^{\circ}$ 62, De 26 De Agosto De 2003.

BRAVO, L. Polyphenols: chemistry, dietary sources, metabolism and nutrition significance. Nutrition Reviews, New York, v.56, n.11, p.317-333, 1998.

BRITO, P.R.B.de.; CARVALHO, Y.M.C.de. Regulamentação do setor de certificação de produtos de qualidade orgânica. In: II Encontro da Associação nacional de Pós Graduação e Pesquisa em Ambiente e Sociedade. Indaiatuba, SP: 2004. 20p.

BURNS, J.C.; NOLLER, C.H.; RHYKERD, C.L.; RUMSEY, T.S . Influence of the fertilization on some organic acids in alfafa, Mediaago sativa L. Crop Science , Madison, v.8, p.1-2, 1968 .

BUTTERY R. G., TERANISHI R., LING L. C. Fresh tomato aroma volatiles: a quantitative study. J. Agric. Food Chem. v.35, p.541-544, 1987.

CAÇO, J. Aminoácidos - nutrientes orgânicos. Hubel Verde - Grupo Hubel. Disponível em:http://www.hubel.pt/fotos/artec/hv_aminoacidos_1288022939.pdf . Acesso em: 10 de março de 2016.

CAMPANHOLA C; VALARINI PJ. A agricultura orgânica e seu potencial para o pequeno agricultor. Cadernos de Ciência \& Tecnologia v.18, p. 69-101, 2001.

CARDOSO, A.L.S.P., TESSARI, E.N.C., CASTRO, A.G.M., KANASHIRO, A.M.L. Pesquisa de Salmonella spp., Coliformes Totais, Coliformes Fecais e Mesófilos em carcaças e produtos derivados de frango. 11 ${ }^{\text {a }}$ Reunião Anual do Instituto Biológico. São Paulo. Nov/2008.

CARLI ,P.; ARIMA, S.; FOGLIANO, V.; TARDELlA, L.; FRUSCIANTE, L.; ERCOLANO, M. R. Use of network analysis to capture key traits affecting tomato organoleptic quality. J. Exp. Bot. v.60, p.3379-3386, 2009.

CARRARI ,F.; FERNIE, A.R. Metabolic regulation underlying tomato fruit development. J Exp Bot. v.57, p.1883-1897, 2006.

CARVALHO, A. P. F.; BUSTAMANTE, M. M.C.; KOZOVITS, A. R.; ASNER, G. P.Variações sazonais nas concentrações de pigmentos e nutrientes em folhas de espécies de cerrado com diferentes estratégias fenológicas. Rev. bras. Bot. [online]., v.30, n.1, p. 19-27. 2007. 
CARVALHO, L.A.C.; MACHINI, M.T. Hemocidinas derivadas da hemoglobina: estruturas, propriedades e perspectivas. Química Nova, v. 36, n.7, p. 1021-1029, 2013.

CASSETARI, L. de S. Controle genético dos teores de clorofila e carotenóides em folhas de alface. 2012. 67p. Dissertação de Mestrado -Universidade Federal de Lavras: UFLA, 2012.

CASTELlANE, P.D. Nutrição Mineral e Qualidade de Olerícolas Folhosas. IN: DE SÁ, M.E.; BUZZETI, S. Importância da Adubação na Qualidade dos Produtos Agrícolas. São Paulo: Ícone, 1994. p. 345-357.

CAVALCANTE, L.F.; DIAS, T.J.; NASCIMENTO, R.; FREIRE, J.L. de O. Clorofila e carotenóides em maracujazeiro- -amarelo irrigado com águas salinas no solo com biofertilizante bovino. Rev. Bras. Frutic., Jaboticabal - SP, Volume Especial, E. p. 699-705, out, 2011.

CEASA-DF. Mercado: boletim mensal Disponível em: http://www.ceasa.gov.br/dados/conjuntura/DF/abr2007.pdf. Acesso em: 02 de agosto de 2007.

CEPEA. Centro de Estudos Avançados em Economia Aplicada - ESALQ/USPHORTIFRUTI BRASIL - Dezembro de 2014/Janeiro de 2015. Disponível em: http://cepea.esalq.usp.br/hfbrasil/edicoes/141/full.pdf. Acesso em: 13 de outubro de 2015.

CHIARADIA, M.C.; COLLINS, C. H., JARDIM, I.C.S.F.O estado da arte da cromatografia associada à espectrometria de massas acoplada à espectrometria de massas na análise de compostos tóxicos em alimentos. Quím. Nova [online]. v.31, n.3, p. 623-636, 2008.

CLARK, R.B. Organic acids and mineral cations of corn plant parts with age. Communications in Soil Science and Plant Analysis, New York, v.7, n.6, p. 585-600, 1976.

CLARK, R.B. Organic acids of Maize (Zea mays L.) as influenced by mineral deficiencies. CropScience, Madison, v.8, p.165-167, 1968.

CLEMENTS, R.S. JR.; DARNELL, B. Myo-inositol content of common foods: development of a high-myo-inositol diet. Am J Clin Nutr. v.33, n.9, p. 1954-1967, 1980.

COMETTI, N. N.; Composto nitrogenado e açucares solúveis em tecidos de alface orgânica, hidropônica e convencional. Horticultura Brasileira, v. 22, n. 4, p. 748-753, 2004.

CÔNSOLO, F. Z. Avaliação das concentrações de magnésio, zinco, cobre, ferro, alumínio, cromo, níquel, cobalto e molibdênio nas hortaliças tuberosas comercializadas e consumidas em Mato Grosso do Sul. 2015. 126p. Tese de Doutorado em Saúde e Desenvolvimento na Região Centro-Oeste. Universidade Federal do Mato Grosso do Sul. 2015.

COSTA, C.A. CASALI, V.W.D. RUIZ, H.A. JORDÃO, C.P. CECON, P.R. Teor de metais pesados e produção de alface adubada com composto de lixo urbano. Horticultura Brasileira, Brasília, v. 19 n. 01, p. 10-16, março, 2001. 
COSTA, E.A., et al. Avaliação microbiológica de alfaces (Lacuta sativa L.) convencionais e orgânicas e a eficiência de dois processos de higienização. Alimentos e Nutrição Araraquara v.23, n.3 387-392, jul./set. 2012

COSTA, R. C. da. Teores de clorofila, produção e qualidade de frutos de morangueiro sob telas de sombreamento em ambiente protegido. 2009. 126p. Dissertação de Mestrado em Agronomia - Universidade de Passo Fundo, 2009.

CRC. Handbook of Chemistry and Physics, 90. Auflage, CRC Press, Boca Raton, Florida. Section 3, Physical Constants of Organic Compounds, p. 3-268. 2009.

CROFT, K.D. The chemistry and biological effects of flavonoids and phenolic acids. Annals of the New York Academy of Science, New York, v.854, p.435-442, 1998.

CULTIVAR. Alface é a folhosa mais consumida no Brasil. Disponível em: http://www.grupocultivar.com.br/noticias/alface-e-a-folhosa-mais-consumida-no-brasil.

acesso em: 12 de março de 2015.

DA SILVA, J.P. Modo de cultivo e sanitização na pós-colheita de repolho híbrido 'Fuyutoyo'. 2013. 85p. Dissertação de Mestrado em Agronomia. Faculdade de Ciências Agronômicas, Universidade Estadual Paulista. 2013.

DAROLT, M. R., STRIGHETA, P., MUNIZ, J. Comparação da qualidade do alimento orgânico com o convencional. Alimentos orgânicos: produção, tecnologia e certificação. Viçosa: UFV, 2003. p. 289-312.

DAROLT, M.R. A sustentabilidade do sistema de agricultura orgânica: um estudo da região metropolitana de Curitiba. 2000.310p. Tese de Doutorado. Universidade Federal do Paraná/Paris VII. 2000. [S.1.], 2001.

DAROLT, M.R. Alimento orgânico ou convencional? Os diferentes aspectos da qualidade nutricional dos alimentos que você consome. Revista Nutrição \& Notícias. v. I, n. 2. p. 2629. 2005.

DE FREITAS, D. A. F., SILVA, M. L. N., AVANZI, J. C. Qualidade do Solo em Áreas de Plantio Convencional Sob Latossolos do Cerrado. XXXIII Congresso Brasileiro de Ciência do Solo. Uberlândia-MG. 2010.

DE SOUZA, L.A. Química presente em alimentos. Disponível em: http://mundoeducacao.bol.uol.com.br/quimica/acido-malico-acido-tartarico-acidofumarico.htm. Acessoem: 04 de janeiro de 2016.

DERVARTANIAN, D.V.; VEEGER, C. Studies on succinate dehydrogenase. I. Spectral properties of the purified enzyme and formation of enzyme-competitive inhibitor complexes. Biochim. Biophys. Acta [S.1.: s.n.] 92: p.233-247. 1964.

DIAS, N.M.P.; ALLEONI, L.R.F.; CASAGRANDE, J.C. ; CAMARGO, O. A. Isotermas de adsorção Isotermas de adsorção de cádmio em solos ácricos de cádmio em solos ácricos. Revista Brasileira de Engenharia Agrícola e Ambiental, v.5, n.2, p.229-234, 2001. 
DIBNER, J.J., BUTTIN, P. Use of organic acid as a model to study the impact of gut microflora on nutrition and metabolism. Journal of Applied Poultry Research v.11, p.453463, 2002.

DIETRICHL, S.M.C; RIBEIRO,R.C.L.F. Carboidratos de reserva em plantas superiores e sua importância para o homem.Revista de la Academia Colombiana de Ciencias exactas, Físicas y Naturales. v. 16, n.61. p. 65-71, nov, 1986.

DING, Y.; LUO, W; XU, G. Caractherization of magnesium nutrient and interaction of magnesium and potassium in rice. Annals of Applied Biology, Warwick, v. 145, p.111-123, 2006.

DÔRES, R.G.R.das; CASALI, V.W.D; Plantas medicinais e aromáticas: controle de qualidade. Minas Gerais: UFV/DFT, 2007. p 29-43.

DUTRA DE OLIVEIRA, J. E.; MARCHINI, J. S. Ciências nutricionais. São Paulo: Sarvier, 1998. $403 \mathrm{p}$.

DWORSKY, P.; HOFFMANN-OSTENHOF, O. L-3-Aldonic acid dehydrogenase from Schwanniomyces occidentalis. Acta Biochim. Pol., v. 11, p. 269-277, 1964.

ELBE, J. H. von. Colorantes. In: FENNEMA, O. W. (Ed.). Quimica de los alimentos. 2. ed. Zaragoza: Wisconsin, 2000. p. 782-799.

EMATER-DF. Informações Agropecuárias do Distrito Federal - 2013. Diponível em: http://www.emater.df.gov.br/index.php?option=com_phocadownload\&view=category\&id=72 \&Itemid=55. Acesso em 16 de março de 2016.

EMBRAPA. Centro Nacional de Pesquisa de Solos. Manual de métodos de análise de solo / Centro Nacional de Pesquisa de Solos. - 2. ed. rev. atual. - Rio de Janeiro, 1997. 212p.

ENGEL, J.B.; TONDO, E.C. TONDO. Avaliação da contaminação microbiológica em diferentes fases do cultivo de alface convencional no Estado do Rio Grande do Sul. XXVI SALÃO DE INICIAÇÃO CIENTÍFICA DA UFRGS. Porto Alegre. 2014.

ENGLARD, S. ; SEIFTER, S. The Biochemical Functions of Ascorbic Acid. Annual Review of Nutrition. n.6, p.365-406, 1986.

ESKIN, M.; SHAHIDI, F. Bioquímica de Alimentos: Tradução da $3^{\mathbf{a}}$ Edição. Rio de Janeiro: Elsevier, 2015. 536p.

FAYAD-ANDRÉ, M. S. Diagnose, disseminação e efeitos fisiológicos do complexo viral do alho em regiões produtoras do Brasil. 2010. 173p. Tese de Doutorado. Brasília: Instituto de Biologia, Universidade de Brasília, 2010.

FERGUSON, L.R., HARRIS, P.J. Protection against cancer by wheat bran: role of dietary fibre and phytochemicals. European Journal of Cancer Prevention, Oxford, v.8, n.1, p.1725, 1999. 
FERNANDES, A.A.; MARTINEZ, H.E.P.; PEREIRA, P.R.G.; FONSECA, M.C.M. Produtividade, acúmulo de nitrato e estado nutricional de cultivares de alface, em hidroponia, em função de fontes de nutrientes. Horticultura Brasileira, Brasília, v. 20, n. 2, p. 195-200, junho, 2002.

FERNANDES, I. T.; GALLO, P. R. ADVÍNCULA, A. O. Avaliação antropométrica de préescolares do município de Mogi-Guaçú, São Paulo: subsídio para políticas públicas de saúde. Rev. Bras. Saúde Matern. Infant., v. 6, n. 2, p. 217-222, 2006.

FERNANDEZ, M.A., SAENZ, M.T., GARCIA, M.D. Antiinflamatory activity in rats and mice of phenolic acids isolated from Scrophularia frutescens. Journal of Pharmacy and Pharmacology, London, v.50, n.10, p.1183-1186, 1998.

FIB. Aminoácidos. Food Ingredients Brasil. Vol. XVI. Ed. 31.p. 72-76. 2014. Disponível em: http://revista-fi.com/edicoes/65/index.html\#p=1. Acesso em 11 de março de 2016.

FIGUEIREDO, P.G.; TAMANATI, F.Y. Adubação orgânica e contaminação ambiental. Revista Verde v. 3, n.3, p. 1-4, 2010.

FILGUEIRA, F. A. R. Novo manual de olericultura: agrotecnologia moderna na produção e comercialização de hortaliças. $2^{a}$ ed., UFV, 2003. 421p.

FONTANÉTTI, A. et al. Adubação verde na produção orgânica de alface americana e repolho. HorticulturaBrasileira, v.24, n.2, p.146-150, 2006.

FOOD AND AGRICULTURE ORGANIZATION OF THE UNITED NATIONS. The Special Programme for Food Security. 2013. Disponível em: <http//www.fao.org/spfs.>. Acesso em 13 de janeiro de 2013.

FOOD INGREDIENTS BRASIL Aplicações do ácido cítrico na indústria de alimentos. FIB no 30 - p. 96-103. 2014. Diponível em: http://www.revista-fi.com/materias/402.pdf. Acesso em: 04 de janeiro de 2016.

FORNASIERI FILHO, D. A cultura do milho. 1 ed. Jaboticabal: Funep, 1992. 273p.

FRANCO, B.D.G.M.; LANDGRAF, M. Microbiologia de alimentos. São Paulo: Editora Atheneu, 2002. 182p.

FU, W.; LI, P.; WU, Y. Effects of different light intensities on chlorophyll fluorescence characteristics and yield in lettuce. Scientia Horticulturae, v.135, p.45-51, 2012.

GAMACHE, P., RYAN, E., ACWORTH, I.N. Analysis of phenolic and flavonoid compounds in juice beverages using high-performance liquid chromatography with coulometric array detection. Journal of Chromatography, Amsterdam, v.635, n.1, p.143$150,1993$.

GIANDON, P. et al. Quality asurance of agricultural products and human health: pesticides residues in grapes, wines and vegetables. In: Fourth Minessota/Padova Conference on Food, Agriculture and the Enviroment, Minessota, Proceedings, 1994. 8p. 
GIMENO, R. M. G.; COSANO, G. Z.; LÓPEZ, M. A. Conservación de los alimentos mediante atmósfera modificada. Vegetales de IV gama. Alimentaría, v. 267, p. 89 -104, 1995.

GOFF,S. A., KLEE. H. J. Plant volatile compounds: sensory cues for health and nutritional value? Science v.311, p. 815-819, fev, 2006.

GOMES, T.M.; BOTREL, T.A.; MODOLO,V.A.; OLIVEIRA,R.F. Aplicação de CO2 via água de irrigação na cultura da alface. Horticultura Brasileira, Brasília, v.23, n.2, p.316-319, abr-jun, 2005.

GONÇALVES JUNIOR, A.C.; LUCHESE, E.B.; LENZI, E. Avaliação da fitodisponibilidade de cádmio, chumbo e crômio, em soja cultivada em latossolo vermelho escuro tratado com fertilizantes comerciais. QUÍMICA NOVA, v. 23, n.2, p. 173-177, 2000.

GONÇALVES, B.R.L.; PEREZ,L.; ÂNGELO, A. C. D. Glicerol: Uma Inovadora Fonte de Energia Proveniente da Produção de Biodiesel. 2nd International Workshop | Advances in Cleaner Production. Key elements for a sustainable world: energy, water and climate change. São Paulo - Brazil - mai, 2009.

GROSS, J. Pigments in vegetables: chlorophylls and carotenoids. Van Nostrand Reinhold, New York. 1991. 351p.

GUASSI, S. A. D. Pós-colheita e potencial antioxidante de alfaces 'Piraroxa'e 'Vanda'. 2012. 82p. Dissertação de Mestrado - Ciência e Tecnologia de Alimentos- Escola Superior de Agricultura Luiz de Queiroz, Universidade de São Paulo, Piracicaba, 2012.

GÜLÇIN, I. Antioxidant activity of caffeic acid (3,4-dihydroxycinnamic acid).Toxicology. v. 217, n.2-3, p. 213-220, jan, 2006.

GUPPY, C.N.; MENZIES, N.W.; MOODY, P.W.; BLAMEY, F.P.C. Competitive sorption reactions between phosphorus and organic matter in soil: A review. Austr. J. Soil Res., v.43, p. 189-202, 2005.

HACQUARD, G. Dicionário de Mitologia Grega e Romana. $1^{\text {a }}$ ediçao. Lisboa: Edições Asa, 1996. 160p.

HALL, D.O.; RAO, K.K. Fotossíntese. São Paulo: EPU/EDUSP, 1980. 89p..

HENRIQUE, B. G; SOUSA,V.P.de; VOLPATO,N.M.; GARCIA,S. Desenvolvimeto e validação de metodologia analítica para a determinação do teor de ácido glicólico na matéria - prima e em formulações dermocosméticas. Brazilian Journal of Phamaceutical Sciences, v. 43, n. 1, p.39-45, jan/ mar. 2007.

HENZ, G. P.; SUINAGA, F.A. Tipos de alface cultivados no Brasil. Brasília, DF: Embrapa Hortaliças. Comunicado Técnico, 75. 2009. 7 p.

HIRAKURI, M. H.; DEBIASI, H.; PROCÓPIO, S. DE O.; FRANCHINI, J.C.; DE CASTRO, C..Sistemas de produção: conceitos e definições no contextoagrícola.-Londrina: Embrapa Soja, 2012. 24 p. 
HOLLMAN, P.C., KATAN, M.B. Bioavailability and health effects of dietary flavonoids in man. Archives of Toxicology Supplement, Berlin, v.20, p.237-248, 1998.

HOLUB, B.J. The nutritional significance, metabolism, and function of myo-inositol and phosphatidylinositol in health and disease. Adv Nutr Res. v.4, p.107-141, 1982.

IBGE - Instituto Brasileiro de Geografia e Estatística - Censo Agropecuário de 2006. Disponível em: www.ibge.gov.br . Acesso em 09 de out 2015.

IEA - Instituto de Economia Aplicada. Banco de dados: área e produção dos principais produtos da agropecuária. Disponível em: http://www.iea.sp.gov.br/out/banco/menu.php. Acesso em : 19 de janeiro de 2014.

INTERNATIONAL FEDERATION OF ORGANIC AGRICULTURAL MOVEMENTS. Basic standards for organic production and processing. In: IFOAM General Assembly. Argentina, 1998.

IVANOVA, A., MILKOVA, T., GALABOV, A.S., NIKOLAEVA, L., VOYNOVA, E. Transformation of cholanic acid derivatives into pharmacologically active esters of phenolic acids by heterogeneous Wittig reaction. Zeitschrift fuer Naturforschung, Tuebingen, v.52, n.7-8, p.516-521, 1997.

JAHN, M.; BAYNES, J.W.; SPITELLER, G. The reaction of hyaluronic acid and its monomers, glucuronic acid and $\mathrm{N}$-acetylglucosamine, with reactive oxygen species. Carbohydr Res. v.321, n.3-4, p.228-234, out,1999.

JENSEN, W. B. J. The Origin of the Names Malic, Maleic, and Malonic Acid. J. Chem. Educ., v. 84, n. 6, p.924, 2007.

KABATA-PENDIAS, A.; MUKHERJEE, A. B. Trace elements from soil to human, 1. ed. Springer, New York. 2007. 576p.

KATAYAMA, M. Nutrição e adubação de alface, chicória e almeirão. In: FERREIRA, M.E.; CASTELlANE, P.D.; CRUZ, M.C.P. Nutrição e adubação de hortaliças. Piracicaba: Potafos, 1993. p. 141-148.

KELLER, F.; MATILE, P.H. The role of vacuole in storage and mobilization of stachyose in tubers of Stachyssieboldíi. J. Plant Physiol. v.119, p.369-380, 1985.

KELLY, S.D.; BATEMAN, I.J. Comparison of mineral concentrations in commercially grown organic and conventional crops - Tomatoes (Lycopersicon esculentum) and lettuces (Lactuca sativa). FoodChemistry, v.119, n.2, p. 738-745, 2010.

KERRY, N.L., ABBEY, M. Red wine and fractionated phenolic compounds prepared from red wine inhibit low density lipoprotein oxidation in vitro. Atherosclerosis, Limerick, v.135, n.1, p.93-102, 1997.

KLUGE, R.A. Fisiologia Vegetal: apontamentos de aulas teóricas de fotossíntese. ESALQ / USP LCB - 311. 2005. Disponível em: 
http://orion.cpa.unicamp.br/sbfv/arquivos/aulas/grade01/

06 fotoquimicadafotossintese/fotossinteseKluge. Acesso em 13 de novembro de 2015.

LAGES, F;. LUCAS, C.; Regulation of Glycerol Transport Genes Gup1 And Gup2 In S. Cerevisiae. Biochem. Biophys. Acta, v. 1322, p.8-18. 1997.

LAWLOS, D.W.; CORNIC, G. Photossinthetic carbon and associated metabolism in relation to water deficit in higher plants. Plant Cell and Environment, v. 25, p.275-294, 2002.

LE COUTEUR, P. Os botões de Napoleão: as 17 moléculas que mudaram a história. Rio de Janeiro: Zahar, 2006.

LEE, P.C., LEE, S.Y., HONG, S.H., CHANG, H.N., LEE, W.G., KWON, S. Batch and continuous cultivation of Anaerobios pirillum succinici producens for the production of succinic acid from whey. Appl Environ Microbiol. v.54, p.23-27, 2000.

LEHNINGER, A. L., NELSON, D. L.; COX, M. M. Principles of Biochemistry. 4th ed. New York: Worth Publishers, 2006. 1216 p.

LEITÃO, M.F. de F.Perigos em Produtos Agrícolas Frescos. In: Elementos e apoio para as boas práticas agrícolas e o sistema APPCC. Brasília, 200p.(Série qualidade e segurança dos alimentos) Convênio: CNI/SENAI/SEBRAE/EMBRAPA, 2004. p.29-60.

LIBERTI, B.; FRANCESCHI, V.R. Oxalate in crop plants .Journal of Agricultural and Food Chemistry, Easton, v.35, p.926-38, 1987.

LINDQUIST, K. On the origin of cultivated lettuce. Hereditas, Lund, v. 46, p. 319-350,1960.

LINHARES, P.C.F. et al. Produção de feijão Mungo em função de diferentes tempos de decomposição dejitirana. Revista Caatinga, v.22, n.1, p.212-216, 2009.

LISEC,J.; SCHAUER,N.; KOPKA,J.; WILLMITZER,L.; FERNIE,A.R. Gas chromatography mass spectrometry-based metabolite profiling in plants. Nat Protoc. v.1, n.1, p.387-396, 2006.

LIU, Y.S.; GUR, A.; RONEN, G.; CAUSSE, M.; DAMIDAUX, R.; BURET, M.; HIRSCHBERG, J.; ZAMIR, D. There is more to tomato fruit colour than candidate carotenoid genes. Plant Biotechnol J v.1, p.195-207, 2003.

LOEWUS, F. Structure and occurrence of inositols in plants. In: Inositol Metabolism in Plants. D.J. Morre, W.F. Boss and F.A. Loewus Wiley-Liss, Inc., New York, 1990. p. 1- 11.

LOEWUS, F.; MURTHY, P. Myo-inositol metabolism in plants. Plant Science. Elsevier Science. v.150, p.1-19, 2000.

LOMMEN, A. MetAlign: interface-driven, versatile metabolomics tool for hyphenated fullscan mass spectrometry data preprocessing. Analytical chemistry. V.81, n.8, p. 3079-3086, 2009. 
MACHADO, S.S.; BUENO, P.R.M.; OLIVEIRA, M.B. DE.; , CELSO JOSÉ DE MOURA, C.J. DE. Concentração de chumbo em alface cultivada com diferentes adubos orgânicos. Revista Brasileira de Produtos Agroindustriais, Campina Grande, v.10, n.1, p.63-70, 2008.

MALDONADE, I. R.; CARVALHO, P. G. B. de; FERREIRA, N. A. Protocolo para determinação de açúcares redutores pelo método de Somogyi-Nelson. Brasília, DF: Embrapa Hortaliças. Comunicado Técnico, 86. 2013. 4 p.

MAltA, O.; GUIMARÃES, A.P. Açúcar. In: Houais A. Enciclopédia Mirador Internacional. Rio de Janeiro: Encyclopaedia Britannica do Brasil Publicações. 1976. p.9397.

MARCHI, E. C. S. Influência da adubação orgânica e de doses de material húmico sobre a produção de alface americana e teores de carbono no solo. 2006. 46 p. Tese de Doutorado em Agronomia-Universidade Federal de Lavras, Lavras, 2006.

MARQUES, M. Galactose. Enciclopédia de Biologia. 2015. Disponível em:http://old.knoow.net/ciencterravida/biologia/galactose.htm. Acessoem 05 de jan. 2016.

MARTINS, I. S.1 ; SILVA, I. M. 2 ; FERREIRA, I.3 ; MELO, L. F.4 ; NOMURA, M. Produtividade da alface em função do uso de diferentes fontes organicas fosfatadas. FAZU em Revista, Uberaba, n.10, p. 36-40, 2013.

MATTIAZZO, M. E., ABREU JUNIOR, C. H., OLIVEIRA, F. C., MARCIANO, C. R., fitodisponibilidade e teores de metais pesados em um latossolo amarelo distrófico e em plantas de cana-de-açúcar adubadas com composto de lixo. Revista Brasileira de Ciência do Solo, v. 26, n. 3, p. 737-746, 2002.

MCKINLAY, J.B., SHACHAR-HILL Y., ZEIKUS J.G., VIEILLE C. Determining Actinobacillus succinogenes metabolic pathways and fluxes by NMR and GC-MS analyses of C-13-labeled metabolic product isotopomers. Metab Eng. v.9, p. 177-192, 2007.

MERCIER, C. Biosynthesis and accumulation of polysaccharides in seeds and tubers. Physiol. Vég. v.23, p. 231-242, 1985.

MERCK INDEX, 11th Edition. Disponível em: https://www.rsc.org/merck-index. Acesso em: 04 de jan. 2016.

MILTENBERGER, K. Hydroxycarboxylic Acids, Aliphatic. IN: Ullmann's Encyclopedia of Industrial Chemistry, Wiley-VCH, Weinheim, 2005. 30080 páginas.

MITCHELL, A.E.; HONG, Y.J; KOH, E.; BARRETT, D.M.; BRYANT, D.E.; DENISON, R.F.; KAFFKA, S.Ten-Year Comparison of the Influence of Organic and. ConventionalCrop 6156 J. Agric. FoodChem., v. 55, n. 15, p. 6154-6159, 2007.

MOHR, H. ; SCHOPFER, P. Plant phisiology. New York: Springer - Verlag, 1995. 629p.

MORAIS, E. G. ; LOPES, M. A. P. ; RESENDE, C. P. ; SILVA, S. ; GONÇALVES, L. D. Uso de húmus sólido e diferentes concentrações de húmus líquido em características agronômicas da alface. Cadernos de Agroecologia . v. 9, n. 4, nov, 2014. 5p. 
MOREIRA, F.R.; MOREIRA J.C. Os efeitos do chumbo sobre o organismo humano e seu significado para a saúde. Rev Panam Salud Publica. v.15, n.2, p. 119-129, 2004.

MOREIRA, I. D. S., DE SOUZA, F. C., DOS SANTOS, F. M., FEITOSA, M. K. D. S. B., MARQUES, L. F. Eficiência de soluções antimicrobiana na desinfecção de alface tipo crespa comercializada em feira livre. Revista Verde de Agroecologia e Desenvolvimento Sustentável, v.8, n. 2, p. 171-177, 2013.

MOTTA, V.T. Bioquímica Básica. LaboratórioAutolab Ltda. 2007. 374p.

MULLER, D.C. Boas Práticas Agrícolas e contaminação microbiana na produção de alfaces orgânicas no Rio Grande do Sul. Salão UFRGS 2014: SIC - XXVI SALÃO DE INICIAÇÃO CIENTÍFICA DA UFRGS. 2014.

MULLER, K.; HIPPE, J. Influence of differences in nutrition on important quality characteristics of some agricultural crops. Plant and Soil, v. 100, n. 1-3, p. 35-45, 1987.

NAGEN, T.J., ALBUQUERQUE, T.T.O., MIRANDA, L.C.G. Ácidos fenólicos em cultivares de soja: ação antioxidante. Arquivos de Biologia e Tecnologia, Curitiba, v.35, n.1, p.129-138, 1992.

NBR ISO 8402. Gestão da Qualidade e Garantia da Qualidade - Terminologia: 1994. $14 \mathrm{p}$.

NELSON, D. L. ; COX, M.M. Lehninger: Princípios de Bioquímica. $3^{\text {a }}$ edição. Editora Sarvier, São Paulo, SP, Brasil. 2002. 955p.

NELSON, K.Y.; LEHNINGER, A.L.; COX; M.M. Princípios de bioquímica. 3.ed. São Paulo: Sarvier; 2000. 1336p.

NEPA - UNICAMP. Tabela brasileira de composição de alimentos - 4. ed. rev. e ampl.. -Campinas: NEPA- UNICAMP, 2011. 161 p.

OLIVEIRA, A.S.; ALMEIDA JÚNIOR, J.F.Proposta de um produto alimentício orgânico e avaliação comparativa de sua aceitação e preferência sensorial. In: Encontro LatinoAmericano de Iniciação Científica, 12., 2008, São José dos Campos. Disponível em: <http://www.inicepg.univap.br/cd/INIC_2008/anais/arquivosINIC/INIC1243_02_A.pdf>.Ace sso em:20 de novembro de 2010.

OLIVEIRA, L.B de; ACCIOLY, A.M. de A.; NASCIMENTO, C.W.A.do; SANTOS, C.L.R. dos; FLORES, R.A.; BARBOSA, F.S. Estado nutricional e teores de metais pesados em plantas de alface adubadas com compostos orgânicos. Biosci. J., Uberlandia, v. 30, supplement 1, p. 199-209, jun, 2014.

OLIVEIRA, P. P. ; COSTA, A. C.; LIMA, W. L. Utilização de Diferentes Dosagens de Esterco em Variedades de Alface. Cadernos de Agroecologia. v. 9, n. 4, nov, 2014. 6p.

O'NEIL, M.J., The Merck Index: An Encyclopedia of Chemicals, Drugs, and Biologicals, 14 ed. New Jersey: Merck, 2006. 
ORMOND, J.G.P.; PACHECO, S.R.L.de P.; FAVERET FILHO, P.; DA ROCHA, L.T.M.. Agricultura orgânica: quando o passado é futuro. BNDES Setorial, Rio de Janeiro, n. 15, p. 3-34, mar, 2002.

PANZENHAGEN, N. V. et al .Aspectos técnico-ambientais da produção orgânica na região citrícola do Vale do Rio Caí, RS. Cienc. Rural, Santa Maria, v. 38, n. 1, fev, 2008 .

PARTHASARATHY, R.; EISENBERG, F. JR. The inositol phospholipids: a stereochemical view of biological activity. Biochemical Journal. V. 235, n. 2, p.313-322, abr, 1986.;

PEDERZOLLI, C.D. Papel do estresse oxidativo na neurotoxidade da 5-oxoprolina e do ácido N-acetilaspártico em encéfalo de ratos. 2008. 227p. Tese de Doutorado. Universidade Federal do Rio Grande do Sul. Instituto de Ciências Básicas da Saúde. Programa de PósGraduação em Ciências Biológicas: Bioquímica. 2008.

PEIXOTO FILHO, J. U.; FREIRE, M. B. G. DOS S., FREIRE, F.J.; MIRANDA, M.F.A.; PESSOA, L. G. M.; KAMIMURA, K.M. Produtividade de alface com doses de esterco de frango, bovino e ovino em cultivos sucessivos. R. Bras. Eng. Agríc. Ambiental, v.17, n.4, p.419-424, 2013.

PELEG, H., BODINE, K.K., NOBLE, A.C. The influence of acid on adstringency of alum and phenolic compounds. Chemical Senses, Oxford, v.23, n.3, p.371-378, 1998.

PENZ J.R., A. M., SILVA, A. B., RODRIGUES, O . Ácidos orgânicos na alimentação de aves. In: Conferência Apinco de Ciência e Tecnologia Avícolas, p.111-119. 1993.

PEREIRA, A.R.; MACHADO, E.C. Análise quantitativa de crescimento de comunidades vegetais. Boletim Técnico. Campinas: Instituto Agronômico/Fundação IAC, 1987. 33 p.

PERI, C. The universe of food quality. Food Quality and Preference. v.17, p. 3-8, 2005.

PIMENTEL, M. S.; LANA, A. M. Q.; DE-POLLI, H. Rendimentos agronômicos em consórcio de alface e cenoura adubadas com doses crescentes de composto orgânico. Revista Ciência Agronômica, v. 40, n. 01, p. 106-112, 2009.

PINTO, S.H.B.; CARVALHO, M.M.de.; HO, L.L. Implementação de programas de qualidade: um survey em empresas de grande porte no Brasil. Gestão \& Produção, v.13, n.2, p.191-203, mai-ago, 2006.

PORTO, V.C.N. et al. Fontes e doses de matéria orgânica na produção de alface. Revista Caatinga,v.12, n.1/2, p.7-11, 1999.

PRETTY, K.M. O potássio e a qualidade da produção agrícola. In: YAMADA, T.; IGUE, K.; MUZILLI, O.; USHERWOOD, N.R. Potássio na agricultura brasileira. Piracicaba: POTAFOS. 1982. p.177-194.

RANSON, S.L. Plant acids. In: PRIDHAM, J.B.; SWAIN , T., ed. Biosynthetic pathways in higher plants. London, Academic Press, 1965. 212p. 
RAVEN, P.H.; JOHNSON, G. B. CAROL J. MILLS (ed), ed. Understanding Biology (3rd ed.). WM C. Brown. 1995. 203p.

REGHIN, M. Y. et al. Cultivo de alface com proteção de agrotêxtil em diferentes períodos. Horticultura Brasileira, Brasília, v. 20, n. 2, jul. Suplemento. 2002.

REN, H.; ENDO, H.; HAYASHI, T. Antioxidative and antimutagenic activities and polyphenol content of pesticide-free and organically cultivated green vegetables using watersolubre chitosan as a soil modifier and leaf surface spray. J SciFood Agric. v.81, p.1426$1432,2001$.

RESENDE, M.; et al. Pedologia. Base para distinção de Ambientes. 5a Edição Ver. Lavras: Editora UFLA, 2007. 322 p.

RIBEIRO, A. C.; GUIMARÃES, P. T. G.; ALVAREZ V., V. H. Recomendação para o uso de corretivos e fertilizantes em Minas Gerais: $5^{\text {a }}$ aproximação. Viçosa, MG: Comissão de Fertilidade do Solo do Estado de Minas Gerais, 1999. 359 p.

RIGON, R. B. Desenvolvimento de diferentes formulações acrescido de ácido glicólico. $17^{\circ}$ amostra acadêmica UNIMEP. Piracicaba. 2009. http// www.unimep.br/phpg/mostraacademicaanais/7mostra/1/222.pdf. Acesso em : 19 de junho de 2013.

RIVALDI, J. D.; SARROUH, B. F. ; FIORILO, R. ; DA SILVA, S. S. Glicerol de biodiesel: Estratégias biotecnológicas para o aproveitamento do glicerol gerado da produção de biodiesel. Biotecnologia Ciência \& Desenvolvimento (Online), v.37, p.44-51, 2008.

RODRIGUES, R. de Q. Avaliação microbiológica e dos sistemas de gestão da inocuidade da cadeia produtiva de alface orgânica no sul do Brasil. 2013. 78p. Dissertação de Mestrado. Universidade Federal do Rio Grande do Sul. Instituto de Ciências e Tecnologia de Alimentos. Programa de Pós-Graduação em Ciência e Tecnologia de Alimentos. Porto Alegre-RS. 2013.

ROLIM, G. de S.; CAMARGO, M.B.P. de; LANIA, D.G.; JENER FERNANDO LEITE DE MORAES, J.F.L. de. Classificação Climática de Köppen e de Thornthwaite e sua Aplicabilidade na Determinação de Zonas Agroclimáticas para o Estado de São Paulo. Bragantia, Campinas, v.66, n.4, p.711-720, 2007.

ROMPRÉ, A. et al. Detection and enumeration of coliforms in drinking water: current methods and emerging. Journal of microbiological methods, v. 49, p. 31-54. 2002.

ROSSETTO, M.R.M.; VIANELLO, F.; ROCHA, S.A.; LIMA, G.P.P. Antioxidant substances and pesticide in parts of beet organic and conventional manure. African Journal of Plant Science. v.3, p.245-253, 2009.

RYDER, E.J. Lettuce Breeding. Breeding Vegetable Crops, AVI Publishing Company, INC. Westport, Connecticut, 1986. 583 p.

SAFFIOTI, W. Fundamentos de Química; Companhia Editora Nacional; São Paulo, Brasil; 1968. 689p. 
SALA, F. C.; COSTA, C. P. da. Retrospectiva e tendência da alfacicultura brasileira. Hortic. Bras. [online]., v.30, n.2, p. 187-194, 2012.

SANDERS, D.C. Lettuce production. Disponível em: $<$ http//WWW.ces.nesu.edu/depts/hort/hil/hil=11>. Acesso em 10 de setembro de 2013.

SANTI, A.; SCARAMUZZA, W.L.M.P ; NEUHAUS,A.; DALLACORT, R.; KRAUSE, W.; TIEPPO, R.C. Desempenho agronômico de alface americana fertilizada com torta de filtro em ambiente protegido. Hortic. Bras. v.31 n.2 , p. 338-343, abr/jun, 2013.

SANTOS, A.P.R. dos; JUNQUEIRA, A.M.R. Gestão da Qualidade na Couve Minimamente Processada no Distrito Federal: O Caso da Agroindústria Machadinho.Revista Brasileira de Produtos Agroindustriais, Campina Grande, v.14, n.4, p.337-352, 2012.

SANTOS, G. C.; MONTEIRO, M. Sistema orgânico de produção de alimentos. Alimentos e Nutrição, Araraquara, v. 15, n. 1, p. 73-86, 2004.

SANTOS, J.C.S. DOS; CORREA, M.G.; SCOLARI, T.; BONOME, L.T.DA.S.; SANTOS, D.DOS;BITTENCOURT, H.VON H. Desempenho Agronômico de Alface Crespa com Aplicação de Fertilizantes Orgânicos e Organominerais. Anais do SEPE - Seminários de Ensino, pesquisa e Extensão da UFFS. v. 3, n. 1. 2013. 2p.

SANTOS, R. H. et al. Efeito residual da adubação com composto orgânico sobre o crescimento e produção de alface. Pesquisa Agropecuária Brasileira, v. 36, n. 11, p. 13951398, 2001.

SANTOS, R. H. S.; CASALI, V. W. D.; CONDÉ, A. R.; MIRANDA, L. C. G. de. Qualidade de alface cultivada com composto orgânico. Horticultura Brasileira, Brasília, v. 12, n. 1, p. 29-32, 1994.

SANTOS, S.A.O.; FREIRE, C. S. R.; DOMINGUES, M. R. M.; SILVESTRE, A. J. D.; NETO, C. P. Characterization of Phenolic Components in Polar Extracts of Eucalyptus globulus Labill. Bark by High-Performance Liquid Chromatography-Mass Spectrometry. Journal of Agricultural and Food Chemistry v.59, n.17, p.9386-9393, 2011.

SAPOLSKY,R. Biology and Human Behavior: The Neurological Origins of Individuality. 2nd edition. The Teaching Company. Guide Book . 2005. p. 19-10.

SIEFERMAN-HARMS D. The light harvesting and protective function of carotenoids in photosynthetic membrane. Physiol Plant. v.69, p.561-568, 1987.

SILVA JUNIOR,E.A.da. Manual de controle higiênico-sanitário em alimentos. São Paulo: Varela, 2001. 475p.

SILVA, E.M.N.C.P. da et al.Qualidade de alface crespa cultivada em sistema orgânico, convencional e hidropônico. Hortic. Bras. [online]. v.29, n.2, p. 242-245, 2011. 
SILVA, N. da; JUNQUEIRA, V.; SILVEIRA, N. F. A.; TANIWAKI, M. H.; SANTOS, R. F. S. dos, GOMES, R. A. R. Manual de métodos de análise microbiológica de alimentos e água.4 edição. São Paulo: Livraria Varela, 2010. 614p.

SILVA, N., EIROA, M.N.U. Avaliação do meio Semi-Sólido Rappaport Vassiliadis Modificado para detecção rápida de Salmonella em alimentos. Coletânea ITAL, Campinas. v.23, n.1, p. 68-77, jan/jun.1993.

SILVA, N.da.; JUNQUEIRA, V.C.A.; SILVEIRA, N.I. Manual de Métodos de AnáliseMicrobiológica de Alimentos. São Paulo: Varela, 1997. 295p.

SILVA, R. do N. et al.Comparação de métodos para a determinação de açúcares redutores e totais em mel. Ciênc. Tecnol. Aliment. [online]., v.23, n.3, p. 337-341, 2003.

SILVA, S. ; DA CRUZ, H. A.; PEREIRA ,T. G. ; NARCISO, J. O. de F. ,GONÇALVES , L. D. Produção de alface (Lactuca sativa L.) submetida a diferentes doses de biofertilizante . Cadernos de Agroecologia. v.9, n. 4, nov, 2014. 5p.

SILVA, V. de P.B.da. Análise da Conformação de Qualidade da Alface Orgânica Produzida no Distrito Federal.Dissertação de Mestrado. Universidade de Brasília / Faculdade de Agronomia e Medicina Veterinária. 2005. 164p.

SINGH, C.P.; AMBERGER, A. Organic acids and phosphorus solubilization in straw composted with rock phosphates. Bioresour. Technol. v.63, p.13-16, 1998.

SINHA, R. K. Modern plant phisiology. Pangbourme: Alpha Science International Ltd., 2004. 620p.

SIQUEIRA, R.S. Manual de microbiologia de alimentos. Brasília: EMBRAPA, 1995. 159 p.

SMILEY, J.D.; ASHWELL, G. Purification and properties of $\beta$-L-hydroxy acid dehydrogenase. II. Isolation of $\beta$-keto-L-gluconic acid, an intermediate in L-xylulose biosynthesis. J. Biol. Chem., v. 236, p. 357-364, 1961.

SMITH, J. L.; FRATAMICO, P. M.; NOVAK, J. S. Quorum sensing: A primer for food microbiologists. Journal of Food Protection, Des Moines, v. 67, n. 5, p. 1053-1070, 2004.

SMITHS DETECTION. Inspeção por raios X. 2013. Disponível em: ttps://www.smithsdetection.com/index.php?option=com_k2\&view=itemlist\&layout=category \&Itemid=600\&lang $=$ pt\&limitstart=406. Acesso em 25 de maio de 2013.

SNEDDEN, W. A.; FROMM, H.Calmodolin, calmodulinrelated proteins and plant responses to the environment. Trends Plant Science, v.3, p. 299-309, 1998.

SOARES, A.; SOBREIRO, F. R., GOMES, M. da S.; DIORNELLAS, A. N., SILVA, R. F. Produtividade de alface em cultivo orgânico utilizando composto à base de dejetos de suíno. Cadernos de Agroecologia. v. 9, n. 4, nov. 2014. 5p. 
SOARES, S. E. Ácidos fenólicos como antioxidantes. Rev. Nutr. [online], v.15, n.1, p. 71-81. 2002.

SODEK, L. Estresse e o Transporte de Aminoácidos no Xilema de Leguminosas. Sociedade Brasileira de Bioquimica e Biologia Molecular. 2002. Disponível em: sbbq.iq.usp.br/arquivos/regional/2002/cdresumo/Palestras/011.pdf. Acesso em 10 de março de 2016.

SOLA, M.C.; OLIVEIRA, A.P.de; FEISTEL, J.C.; REZENDE, C.S.M. e. Mecanismos de Quorum Sensing e sua relevância na microbiologia de alimentos. ENCICLOPÉDIA BIOSFERA, Centro Científico Conhecer - Goiânia, v.8, n.14; p. 1419 - 1441, 2012.

SONG, H., LEE, S.Y. Process for the production of succinic acid by anaerobic fermentation. US v.5, n. 143, p.833. 2006.

SOUSA, C. A. F.; SODEK, L. The metabolic response of plants to oxygen deficiency. Brazilian Journal Plant Physiology, v. 14, n. 2, p. 83-94, 2002.

SOUZA, J.L.; RESENDE, P. Manual de Horticultura Orgânica. 2 ed. Viçosa: 199 Aprenda Fácil Editora, 2006. 843 p..

SOUZA, J.L.; RESENDE, P. Manual de horticulturaorgânica. Viçosa: AprendaFácil, 2003. $564 p$.

SPERS, E.E. Segurança do alimento. In: Gestão da Qualidade no Agribusiness: estudos e casos. São Paulo: Atlas, 2003. p.60-79.

STEENHOUDT, O., VANDERLEYDEN, J. Azospirillum, a free-living nitrogen-fixing bacterium closely associated with grasses: genetic, biochemical and ecological aspects. FEMS Microbiology Reviews, v.24, p.487-506. 2000.

STEINHAUSER, M.-C.; STEINHAUSER, D.; KOEHL, K.; CARRARI, F.; GIBON, Y.; FERNIE, A. R.; et al. Enzyme activity profiles during fruit development in tomato cultivars and Solanum pennellii. Plant Physiol. v.153, p.80-98. 2010.

STUMPF, P. K. 8; E. E. CONN. The Biochemistry of Plants. A Comprehensive Treatise. Vol. 3. Carbohydrates: Structure and Function. J. Preiss (Ed) Academic Press. N. Y. 1980. $644 \mathrm{p}$.

SUN, J.; NISHIO, J. N.; VOGELMANN, T. C. Green light drives $\mathrm{CO}^{2}$ fixation deep within leaves. Plant Cell Physiology, v.39, p.1020-1026, 1998.

TAIZ, L.; ZEIGER, E. Fisiologia vegetal. 4.ed. Porto Alegre: Artmed, 2009. 819p.

TAIZ, L.; ZEIGER, E. Fisiologia vegetal. São Paulo: Artmed, 2004. 719p.

TALAMINI, E.; PEDROZO, E. A.; SILVA, A.L.da. Gestão da cadeia de suprimentos e a segurança do alimento: uma pesquisa exploratória na cadeia exportadora de carne suína. Gestão\&Produção, v.12, n.1, p.107-120, jan-abr. 2005. 
TIEMAN, D.; BLISS, P.; MCINTYRE, L. M.; BLANDON-UBEDA, A.; BIES, D.; ODABASI, A. Z; et al. The Chemical interactions underlying tomato flavor preferences. Curr. Biol. v.22, p.1035-1039, 2012.

TURAZI, C.M.V.; JUNQUEIRA, A.M.R.; QUADROS, M. Peso médio de alface cv Verônica sob cultivo protegido no Distrito Federal em função de fontes e doses de adubos orgânicos. In: CONGRESSO BRASILEIRO DE OLERICULTURA, 44., 2004, Campo Grande. Anais...Campo Grande: SOB 1 CD.

VAN HEES, P. A. W.; LUNDSTROM, U. S.; GIESLER, R. Low molecular weight organic acids and their Al-complexes in soil solutionc-compostion, distribution ans seasonal variation in three podzolized soils. Geoderma v.94, p. 173- 200, 2000.

VIANA, E. M.; VASCONCELOS, A. C. F. Produção de alface adubada com termofosfato e adubos orgânicos.Revista Ciência Agronômica, v. 39, n. 02, p. 217-224, 2008.

VIEIRA, E. L.; SOUZA, G. S. de; SANTOS, A. R. dos; SILVA, J.dos S. Manual de Fisiologia Vegetal. São Luís, MA: EDUFMA, 2010. 230p.

VIGGIANO, J. Produção de sementes de alface. In: CASTELLANE, P.D.; NICOLOSI, W.M.; HASE- GAWA, M. (Ed.). Produção de sementes hortaliças. Jaboticabal: FUNEP, 1990. p.1-13.

VILELA, N.J. et al. Perfil dos consumidores de produtos orgânicos no Distrito Federal. Disponível em: <http://www.cnph.embrapa.br/paginas/serie_documentos/publicacoes2006/cot_40.pdf>. Acesso em: 22 de outubro de 2015.

VOLLHARDT, K.P.C, SCORE, N.E., Organic Chemistry (2nd edition), W.H.Freeman and Company, New York .1994. p.1031-1034.

VOLLHARDT, K. P. C. Química Orgánica, Barcelona: Ediciones Omega S.A. 1994.

WANG, Y.; XU, L.; SHEN, H.; WANG, J.; LIU, W.; ZHU,X.; WANG, R.; SUN, X.; LIU, L.Metabolomic analysis with GC-MS to reveal potential metabolites and biological pathways involved in $\mathrm{Pb} \& \mathrm{Cd}$ stress response of radish roots. Scientific Reports. v.5 n. 18296, p. 1-13. 2015.

WANG, Z.X.; ZHUGE, J.; FANG, H.; PRIOR, B.A. Glycerol production by microbial fermentation: a review. Biotechnol Adv. V.19, n.3, p. 201-223, jun, 2001.

WANG,Y.M.; VAN EYS, J. Nutritional significance of fructose and sugar alcohols. Ann Rev Nutr. v.1, p.437-475, 1981.

WEERT, S., VERMEIREN, H., MULDERS, I. H. M., KUIPER, I., HENDRICKX, N., BLOEMBERG, G.N., VANDERLEYDEN, J., MOT, R., LUGTENBERG, B.J.J. Flagelladriven chemotaxis towards exudate components is an important trait for tomato root colonization by Pseudomonas fluorescens. Molecular plant. v.11, p,1173-1180, 2002. 
WELBURN, A.R. The spectral determination of chlorophylls a and $b$, as well as total carotenoids, using various solvents with spectrophotometers of different resolution.Journal of Plant Physiology, v. 144, p. 307-313, 1994.

WHISTLER, R. 1..\& C. L. SMART. Polysaccharide Chemistry. Academic Press Inc.. Publ. New York, 1953. 493 p.

WINZER, K.; HARDIE, K. R.; WILLIAMS, P. Bacterial cell-to-cell communication: sorry, can't talk now gone to lunch! Current opinion in Microbiology, Oxford, v. 5, n. 2, p. 216222, abr, 2002.

XU, J. M.; TANG, C.; CHEN, Z. L.; Chemical composition controls residue decomposition in soils differing in initial pH. Soil Biol. Biochem. v.38, p. 552, 2006.

XU, Q.; WANG, Y.; DING, Z.; SONG, L.; LI, Y.; DEXIN MA, D.; WANG, Y.; SHEN, J.; JIA, S.; SUN, H; ZHANG, H. Aluminum induced metabolic responses in two tea cultivars. Plant Physiology and Biochemistry. v.101. p.162-172, 2016.

YAMADA, T. Resistência de plantas às pragas e doenças: pode ser afetada pelo manejo da cultura? InformaçõesAgronômicas n.108 ,dez, 2004.

YANG, X.J.; KOW, L.M.; FUNABASHI, T.; MOBBS, C.V. Hypothalamic glucose sensor: similarities to and differences from pancreatic beta-cell mechanisms. Diabetes. v.48, n.9, p. 1763-1772, set, 1999.

YURI, J. E. et al. Efeito de composto orgânico sobre a produção e características comerciais de alface americana. Horticultura Brasileira, v. 22, n. 1, p. 127-130, 2004.

ZEIKUS, J.G, JAIN, M.K., ELANKOVAN P,.Biotechnology of succinic acid production and markets for derived industrial products. Appl Microbiol Biotechnol. v.51, n.5, p.545-552. 1999.

ZOCCHE, C.M.; ZOCCHE, J.J.; DOS SANTOS, C.E.I.; ALEXANDRE, N.Z.; DIAS, J.F.; DE ANDRADE, V.M. Hortaliças Cultivadas Sobre Depósitos de Rejeitos de Carvão Mineral: A Concentração de Metais Pesados e os Riscos à Saúde Humana. XI Congresso de Ecologia do Brasil, Porto Seguro - BA, Setembro. 2013. 


\section{ANEXO 1}

Número Mais provável (NMP) e intervalo de confiança a nível de 95\% de probabilidade, para diversas combinações de tubos positivos em série de três tubos. Quantidade inoculada da amostra: 0,1 - 0,01 e 0,001g ou mL (ASSOCIATION OF OFFICIAL ANALYTICAL CHEMISTS- Bacteriological Analytical Manual, 6.ed. Estados Unidos: Food and Drug Administration, 1984).

\begin{tabular}{|c|c|c|c|}
\hline \multirow[b]{2}{*}{$\begin{array}{c}\text { Combinação de } \\
\text { tubos }+\end{array}$} & \multirow[b]{2}{*}{$\mathrm{NMP} / \mathrm{ml}$ ou $\mathrm{NMP} / \mathrm{g}$} & \multicolumn{2}{|c|}{ Intervalo de confiança $(95 \%)$} \\
\hline & & Mínimo & Máximo \\
\hline $0-0-0$ & $<3$ & $<0,5$ & $<9$ \\
\hline $0-0-1$ & 3 & $<0,5$ & 9 \\
\hline $0-1-0$ & 3 & $<0,5$ & 13 \\
\hline $0-2-0$ & - & - & - \\
\hline $1-0-0$ & 4 & $<0,5$ & 20 \\
\hline $1-0-1$ & 7 & 1 & 21 \\
\hline $1-1-0$ & 7 & 1 & 23 \\
\hline $1-1-1$ & 11 & 3 & 36 \\
\hline $1-2-0$ & 11 & 3 & 36 \\
\hline $2-0-0$ & 9 & 1 & 36 \\
\hline $2-0-1$ & 14 & 3 & 37 \\
\hline $2-1-0$ & 15 & 3 & 44 \\
\hline $2-1-1$ & 20 & 7 & 89 \\
\hline $2-2-0$ & 21 & 4 & 47 \\
\hline $2-2-1$ & 28 & 10 & 150 \\
\hline $2-3-0$ & - & - & - \\
\hline $3-0-0$ & 23 & 4 & 120 \\
\hline $3-0-1$ & 39 & 7 & 130 \\
\hline $3-0-2$ & 64 & 15 & 380 \\
\hline $3-1-0$ & 43 & 7 & 210 \\
\hline $3-1-1$ & 75 & 14 & 230 \\
\hline $3-1-2$ & 120 & 30 & 380 \\
\hline $3-2-0$ & 93 & 15 & 380 \\
\hline $3-2-1$ & 150 & 30 & 440 \\
\hline $3-2-2$ & 210 & 35 & 470 \\
\hline $3-3-0$ & 240 & 36 & 1.300 \\
\hline $3-31$ & 460 & 71 & 2.400 \\
\hline $3-3-2$ & 1.100 & 150 & 4.800 \\
\hline $3-3-3$ & $\geq 2.400$ & $>150$ & $>4.800$ \\
\hline
\end{tabular}




\begin{abstract}
ANEXO 2
Padrões Microbiológicos Sanitários para Alimentos

1. A tolerância é máxima e os padrões são mínimos para os diferentes grupos de produtos alimentícios, constantes no presente anexo, para fins de registro e fiscalização de produtos alimentícios. Estes limites e critérios podem ser complementados quando do estabelecimento de programas de vigilância e rastreamento de microrganismos patogênicos e de qualidade higiênica e sanitária de produtos (consultar Princípios e Procedimentos Gerais e os Anexos II).

2. No caso de análise de produtos não caracterizados nas tabelas especificadas neste Anexo, considera-se a similaridade da natureza e do processamento do produto, como base para seu enquadramento nos padrões estabelecidos para um produto similar, constante no referido Anexo I deste Regulamento.
\end{abstract}

\begin{tabular}{|c|c|c|c|c|c|c|}
\hline \multirow[t]{2}{*}{ Grupo de alimento } & \multirow[t]{2}{*}{ Microrganismo } & \multirow[t]{2}{*}{$\begin{array}{l}\text { Tolerância para } \\
\text { Amostra } \\
\text { INDICATIVA }\end{array}$} & \multicolumn{4}{|c|}{$\begin{array}{l}\text { Tolerância para } \\
\text { Amostra } \\
\text { Representativa }\end{array}$} \\
\hline & & & $\mathrm{n}$ & $\mathrm{c}$ & $\mathrm{m}$ & M \\
\hline \multicolumn{7}{|c|}{2 HORTALIÇAS, legumes e similares, incluindo COGUMELOS (fungos comestíveis) } \\
\hline $\begin{array}{l}\text { a) frescas, "in natura", inteiras, } \\
\text { selecionadas ou não, com } \\
\text { exceção de cogumelos }\end{array}$ & $\begin{array}{l}\text { Salmonella } \\
\mathrm{sp} / 25 \mathrm{~g}\end{array}$ & Ausente & 5 & 0 & Aus & - \\
\hline $\begin{array}{l}\text { b) frescas, "in natura", preparadas } \\
\text { (descascadas ou selecionadas ou } \\
\text { fracionadas) sanificadas, } \\
\text { refrigeradas ou congeladas, para } \\
\text { consumo direto, com exceção de } \\
\text { cogumelos }\end{array}$ & $\begin{array}{l}\text { Coliformes a } 45^{\circ} \\
\mathrm{C} / \mathrm{g}\end{array}$ & $10^{2}$ & 5 & 2 & 10 & $10^{2}$ \\
\hline
\end{tabular}

Onde:

Amostra indicativa é a amostra composta por um número de unidades amostrais inferior ao estabelecido em plano amostral constante na legislação específica.

Amostra representativa é a amostra constituída por um determinado número de unidades amostrais estabelecido de acordo com o plano de amostragem.

$\underline{\text { m}}$ : é o limite que, em um plano de três classes, separa o lote aceitável do produto ou lote com qualidade intermediária aceitável.

$\underline{\text { M}}$ : é o limite que, em plano de duas classes, separa o produto aceitável do inaceitável. Em um plano de três classes, M separa o lote com qualidade intermediária aceitável do lote inaceitável. Valores acima de M são inaceitáveis

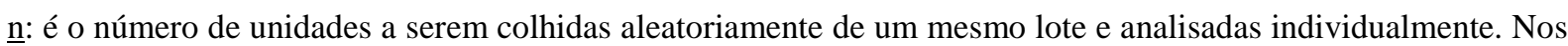
casos nos quais o padrão estabelecido é ausência em $25 \mathrm{~g}$, como para Salmonella sp e Listeria monocytogenes e outros patógenos, é possível a mistura das alíquotas retiradas de cada unidade amostral, respeitando-se a proporção p/v (uma parte em peso da amostra, para 10 partes em volume do meio de cultura em caldo).

c: é o número máximo aceitável de unidades de amostras com contagens entre os limites de m e M (plano de três classes). Nos casos em que o padrão microbiológico seja expresso por "ausência", c é igual a zero, aplica-se o plano de duas classes. 


\section{ANEXO 3}

Compostos não significativos, em unidades arbitrárias por mg, emfolhas de alface provenientes de plantas cultivadas no período de agosto a outubro de 2012 sob diferentes tipos de fertilização. UnB-FAV, 2016.

\begin{tabular}{|c|c|c|c|c|c|c|c|c|c|c|}
\hline & Químico & Bovino & Ovino & Aves & $\begin{array}{c}\text { Composto } \\
\text { Orgânico }\end{array}$ & $\begin{array}{c}\text { Químico+ } \\
\text { bovino }\end{array}$ & $\begin{array}{l}\text { Químico+ } \\
\text { ovino }\end{array}$ & $\begin{array}{l}\text { Químico+ } \\
\text { aves }\end{array}$ & $\begin{array}{c}\text { Químico+ } \\
\text { Cama }\end{array}$ & $\begin{array}{c}\text { Cama de } \\
\text { frango }\end{array}$ \\
\hline Ác. Glicólico & $0,9855 a$ & $1,0402 \mathrm{a}$ & $1,4790 \mathrm{a}$ & $1,4790 \mathrm{a}$ & $1,1465 \mathrm{a}$ & $1,2121 \mathrm{a}$ & $1,1632 \mathrm{a}$ & $0,9633 a$ & $1,3155 \mathrm{a}$ & $0,9517 \mathrm{a}$ \\
\hline Alanina & $0,9228 \mathrm{a}$ & $1,5108 \mathrm{a}$ & $0,8297 a$ & $1,0502 \mathrm{a}$ & $1,2948 a$ & $1,1942 \mathrm{a}$ & $1,1419 a$ & $0,7584 a$ & $1,1076 a$ & $1,1189 a$ \\
\hline Malonato & $0,8809 a$ & $1,4079 a$ & $0,6978 \mathrm{a}$ & $1,5165 a$ & $1,5312 \mathrm{a}$ & $0,9090 \mathrm{a}$ & $1,1291 \mathrm{a}$ & $1,2131 \mathrm{a}$ & $1,0663 \mathrm{a}$ & $0,9298 \mathrm{a}$ \\
\hline Glicerol & $0,9438 \mathrm{a}$ & $0,7683 a$ & $0,8315 a$ & $0,7800 \mathrm{a}$ & $1,1264 \mathrm{a}$ & $0,8642 \mathrm{a}$ & $1,0133 \mathrm{a}$ & $0,8642 \mathrm{a}$ & $0,9825 a$ & $1,0167 \mathrm{a}$ \\
\hline Succinato & $0,9812 \mathrm{a}$ & $1,0276 a$ & $0,8131 \mathrm{a}$ & $0,9171 \mathrm{a}$ & $1,0734 \mathrm{a}$ & $1,0284 \mathrm{a}$ & $0,9765 \mathrm{a}$ & $1,1809 a$ & $0,9364 a$ & $0,8682 \mathrm{a}$ \\
\hline Glicerato & $0,9169 a$ & $0,6946 \mathrm{a}$ & $0,5131 \mathrm{a}$ & $0,6340 \mathrm{a}$ & $0,7551 \mathrm{a}$ & $0,7123 a$ & $0,7634 a$ & $0,6417 \mathrm{a}$ & $0,5379 a$ & $0,7442 \mathrm{a}$ \\
\hline Fumarato & $0,9805 \mathrm{a}$ & $0,6999 a$ & $0,5389 a$ & $0,6402 \mathrm{a}$ & $1,1290 \mathrm{a}$ & $0,4765 a$ & $0,6515 \mathrm{a}$ & $0,6213 a$ & $0,4644 a$ & $0,5116 \mathrm{a}$ \\
\hline Malato & $1,0355 \mathrm{a}$ & $0,7651 \mathrm{a}$ & $0,7366 a$ & $0,7150 \mathrm{a}$ & $0,9121 \mathrm{a}$ & $0,9496 a$ & $0,9956 a$ & $0,9727 \mathrm{a}$ & $0,9555 a$ & $0,5909 a$ \\
\hline P-Homoserina & $1,0383 \mathrm{a}$ & $1,0079 a$ & $0,8529 a$ & $0,8266 a$ & $1,4204 a$ & $0,9466 a$ & $0,8022 \mathrm{a}$ & $0,9293 \mathrm{a}$ & $0,7567 \mathrm{a}$ & $1,0470 \mathrm{a}$ \\
\hline Treonato & $1,0484 \mathrm{a}$ & $1,1341 \mathrm{a}$ & $0,6912 \mathrm{a}$ & $1,3092 \mathrm{a}$ & $1,4106 a$ & $1,1317 \mathrm{a}$ & $0,8343 a$ & $1,1747 \mathrm{a}$ & $1,2263 \mathrm{a}$ & $1,0670 \mathrm{a}$ \\
\hline Glutamato & $0,8491 \mathrm{a}$ & $1,6362 \mathrm{a}$ & $0,5796 a$ & $0,8423 a$ & $0,9656 a$ & $0,9723 a$ & $1,2332 \mathrm{a}$ & $1,1554 \mathrm{a}$ & $1,1038 \mathrm{a}$ & $0,8974 a$ \\
\hline Citrato & $0,9760 a$ & $1,1098 \mathrm{a}$ & $1,2869 a$ & $1,2631 \mathrm{a}$ & $1,3747 \mathrm{a}$ & $1,0495 \mathrm{a}$ & $1,2272 \mathrm{a}$ & $0,6779 a$ & $1,0897 \mathrm{a}$ & $0,8855 \mathrm{a}$ \\
\hline Frutose & $1,0544 \mathrm{a}$ & $0,7551 \mathrm{a}$ & $0,7479 a$ & $0,8059 a$ & $0,8254 a$ & $0,7885 a$ & $0,8670 \mathrm{a}$ & $0,8136 a$ & $0,8178 \mathrm{a}$ & $0,9792 \mathrm{a}$ \\
\hline Ác. Quinico & $1,0421 \mathrm{a}$ & $0,8346 a$ & $0,5936 a$ & $1,0296 \mathrm{a}$ & $1,0717 \mathrm{a}$ & $0,8185 \mathrm{a}$ & $0,7863 a$ & $0,9590 \mathrm{a}$ & $0,7724 a$ & $0,9010 \mathrm{a}$ \\
\hline Galactose & $1,0558 \mathrm{a}$ & $0,7645 a$ & $0,6756 a$ & $1,0442 \mathrm{a}$ & $1,2382 \mathrm{a}$ & $0,8357 \mathrm{a}$ & $0,7417 \mathrm{a}$ & $0,9694 a$ & $0,9889 a$ & $0,9459 a$ \\
\hline myo-Inositol & $0,9347 \mathrm{a}$ & $0,8278 \mathrm{a}$ & $0,8958 \mathrm{a}$ & $0,9380 \mathrm{a}$ & $1,0329 a$ & $1,0490 \mathrm{a}$ & $0,9870 \mathrm{a}$ & $0,9094 a$ & $0,8355 a$ & $0,8223 a$ \\
\hline Glucopiranose & $1,2454 \mathrm{a}$ & $0,0037 \mathrm{a}$ & $0,0088 \mathrm{a}$ & $0,0422 \mathrm{a}$ & $0,0067 \mathrm{a}$ & $1,3817^{\mathrm{a}}$ & $0,0092 \mathrm{a}$ & $0,0097 \mathrm{a}$ & $0,0042 \mathrm{a}$ & $0,0039 a$ \\
\hline Gulonato & $0,9610 \mathrm{a}$ & $0,9552 a$ & $0,7073 a$ & $1,3331 \mathrm{a}$ & $0,8271 \mathrm{a}$ & $0,8095 \mathrm{a}$ & $1,1731 \mathrm{a}$ & $0,9852 a$ & $1,0520 \mathrm{a}$ & $1,0628 \mathrm{a}$ \\
\hline Ác. Caféico & $1,1592 \mathrm{a}$ & $1,1105 \mathrm{a}$ & $0,2212 \mathrm{a}$ & $1,0750 \mathrm{a}$ & $1,4129 a$ & $0,7812 \mathrm{a}$ & $0,4692 a$ & $0,7098 \mathrm{a}$ & $0,5202 a$ & $1,1738 \mathrm{a}$ \\
\hline Sacarose & $0,9328 \mathrm{a}$ & $2,3105 a$ & $1,6873 \mathrm{a}$ & $1,1727 \mathrm{a}$ & $0,7734 \mathrm{a}$ & $1,2351 \mathrm{a}$ & $1,3786 a$ & $1,2336 a$ & $0,8562 \mathrm{a}$ & $0,4154 a$ \\
\hline
\end{tabular}

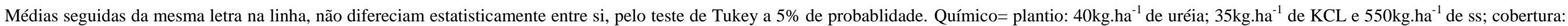

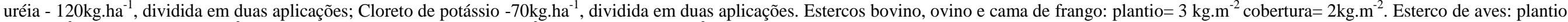
$1,5 \mathrm{~kg} \cdot \mathrm{m}^{-2}$, cobertura $=; 0,5 \mathrm{~kg} \cdot \mathrm{m}^{-2}$. Composto orgânico: plantio $=0,5 \mathrm{~kg} \cdot \mathrm{m}^{-2}$, cobertura $=0,5 \mathrm{~kg} \cdot \mathrm{m}^{-2} . *$ Concentrações normalizadas pelo tratamento com fertilização química. 


\section{ANEXO 4}

Compostos não significativos, em unidades arbitrárias por mg,emfolhas de alface provenientes de plantas cultivadas no período de fevereiro a abril de 2013 sob diferentes tipos de fertilização. UnB-FAV, 2016.

\begin{tabular}{|c|c|c|c|c|c|c|c|c|c|c|}
\hline & Químico & Bovino & Ovino & Aves & $\begin{array}{c}\text { Composto } \\
\text { Orgânico }\end{array}$ & $\begin{array}{l}\text { Químico+ } \\
\text { bovino }\end{array}$ & $\underset{\text { ovino }}{\text { Químico+ }}$ & $\begin{array}{l}\text { Químico+ } \\
\text { aves }\end{array}$ & $\begin{array}{c}\text { Químico+ } \\
\text { Cama }\end{array}$ & $\begin{array}{c}\text { Cama de } \\
\text { frango }\end{array}$ \\
\hline Alanina & $1,0000 \mathrm{a}$ & $1,4929 a$ & $2,0687 \mathrm{a}$ & $2,0830 \mathrm{a}$ & $1,2073 a$ & $2,2149 a$ & $2,5586 a$ & $3,0772 \mathrm{a}$ & $1,5117 \mathrm{a}$ & $1,1254 a$ \\
\hline Glicerol & $1,0000 \mathrm{a}$ & $1,4434 \mathrm{a}$ & $1,3329 a$ & $1,5144 \mathrm{a}$ & $1,2659 \mathrm{a}$ & $1,5658 \mathrm{a}$ & $1,6630 \mathrm{a}$ & $1,4640 \mathrm{a}$ & $1,1023 \mathrm{a}$ & $1,3573 \mathrm{a}$ \\
\hline Glicerato & $1,0000 \mathrm{a}$ & $1,0665 \mathrm{a}$ & $1,5230 \mathrm{a}$ & $1,1753 \mathrm{a}$ & 1,1491a & $1,1093 \mathrm{a}$ & $1,3692 \mathrm{a}$ & 0,9460a & $0,7492 \mathrm{a}$ & $1,1523 \mathrm{a}$ \\
\hline Fumarato & $1,0000 \mathrm{a}$ & 1,4471a & 0,7390a & $0,9427 \mathrm{a}$ & $1,3939 a$ & $0,7403 \mathrm{a}$ & $0,4560 \mathrm{a}$ & $1,5454 \mathrm{a}$ & $1,4385 a$ & $0,4560 \mathrm{a}$ \\
\hline P-Homoserina & $1,0000 \mathrm{a}$ & $1,2561 \mathrm{a}$ & $1,0348 \mathrm{a}$ & $1,3389 \mathrm{a}$ & $1,0184 \mathrm{a}$ & $0,8088 \mathrm{a}$ & $1,4327 \mathrm{a}$ & $0,9991 \mathrm{a}$ & $0,9368 \mathrm{a}$ & $0,8758 \mathrm{a}$ \\
\hline Gaba & $1,0000 \mathrm{a}$ & 1,0016a & $1,0233 \mathrm{a}$ & $0,9991 \mathrm{a}$ & $1,0017 \mathrm{a}$ & $0,9986 a$ & $1,0121 \mathrm{a}$ & $1,0488 \mathrm{a}$ & $0,9702 \mathrm{a}$ & $1,0366 \mathrm{a}$ \\
\hline Eritronato & $1,0000 \mathrm{a}$ & 1,9886a & $1,4492 \mathrm{a}$ & $1,6912 \mathrm{a}$ & $1,3249 \mathrm{a}$ & $1,6616 a$ & $1,1734 \mathrm{a}$ & $2,1011 \mathrm{a}$ & $1,9355 \mathrm{a}$ & $1,6983 a$ \\
\hline Treonato & $1,0000 \mathrm{a}$ & 2,0986a & 1,9180a & 1,6980a & $1,6054 \mathrm{a}$ & $1,4984 a$ & $2,5741 \mathrm{a}$ & $2,3005 \mathrm{a}$ & $1,4146 a$ & $1,2958 \mathrm{a}$ \\
\hline Glutamato & $1,0000 \mathrm{a}$ & $2,3416 \mathrm{a}$ & $2,5124 \mathrm{a}$ & $1,5952 \mathrm{a}$ & $1,0581 \mathrm{a}$ & $2,9359 a$ & $2,7319 a$ & $3,2196 a$ & $2,4540 \mathrm{a}$ & $2,0102 \mathrm{a}$ \\
\hline Citrato & $1,0000 \mathrm{a}$ & $1,8908 \mathrm{a}$ & $1,2630 \mathrm{a}$ & $1,2863 \mathrm{a}$ & $1,5883 \mathrm{a}$ & $1,5834 \mathrm{a}$ & $1,4535 \mathrm{a}$ & $1,6456 a$ & $1,5263 \mathrm{a}$ & $1,1365 \mathrm{a}$ \\
\hline Frutose & $1,0000 \mathrm{a}$ & $1,0444 \mathrm{a}$ & $1,1125 \mathrm{a}$ & $0,9991 \mathrm{a}$ & $1,0189 \mathrm{a}$ & $0,9986 a$ & $1,0121 \mathrm{a}$ & $1,0488 \mathrm{a}$ & $0,9702 \mathrm{a}$ & $1,0366 a$ \\
\hline Ác. Quinico & $1,0000 \mathrm{a}$ & $1,4656 a$ & $1,1544 \mathrm{a}$ & $1,4662 \mathrm{a}$ & $1,3009 a$ & $1,1989 \mathrm{a}$ & $1,1653 a$ & $1,4887 \mathrm{a}$ & $1,3936 a$ & $0,7647 a$ \\
\hline Galactose & $1,0000 \mathrm{a}$ & 1,0609a & $0,9013 a$ & $1,2898 \mathrm{a}$ & $1,0466 \mathrm{a}$ & $0,9276 a$ & $1,0984 \mathrm{a}$ & $0,9894 a$ & $0,6622 \mathrm{a}$ & $0,8408 \mathrm{a}$ \\
\hline myo-Inositol & $1,0000 \mathrm{a}$ & 0,9139a & $0,8204 a$ & $0,7800 \mathrm{a}$ & $0,9291 \mathrm{a}$ & $0,8851 \mathrm{a}$ & $1,3762 \mathrm{a}$ & $0,8979 a$ & $0,7432 \mathrm{a}$ & $1,5430 \mathrm{a}$ \\
\hline Glucopiranose & $1,0000 \mathrm{a}$ & $6,0387 \mathrm{a}$ & $2,4545 a$ & $5,5404 \mathrm{a}$ & $7,2656 a$ & $2,9602 \mathrm{a}$ & $5,0678 \mathrm{a}$ & $2,0412 \mathrm{a}$ & $5,6169 a$ & $3,4153 a$ \\
\hline Sacarose & $1,0000 \mathrm{a}$ & 1,4391a & $0,5458 \mathrm{a}$ & $1,9709 a$ & $1,0700 \mathrm{a}$ & $0,9200 \mathrm{a}$ & $2,3510 \mathrm{a}$ & $4,1474 a$ & $0,7732 \mathrm{a}$ & $2,6135 \mathrm{a}$ \\
\hline
\end{tabular}

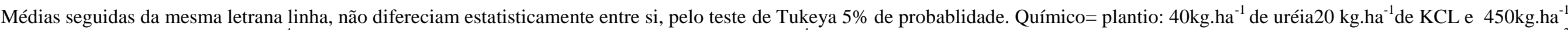

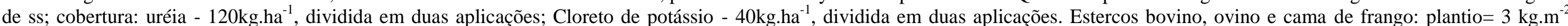

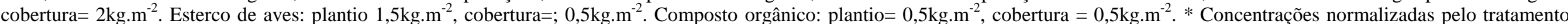
com fertilização química. 